\title{
Palynostratigraphy and palaeoenvironments of the Rævekløft, Gule Horn and Ostreaelv Formations (Lower-Middle Jurassic), Neill Klinter Group, Jameson Land, East Greenland
}

\author{
Eva B. Koppelhus and Gregers Dam
}

The Neill Klinter Group of Jameson Land, East Greenland contains rich and diverse palynomorph assemblages. Spores, pollen and freshwater algae dominate most of the samples, but dinoflagellate cysts and acritarchs also form important components. The ages suggested by the palynomorphs from the Rævekløft, Gule Horn and Ostreaelv Formations span the period from the Early Pliensbachian to the early Aalenian. The number of palynomorphs identified totals 136, including 83 miospore and 53 microplankton species; they are grouped into seven palynological assemblage zones.

In general, there is good agreement between the palynological and sedimentological data, and the palynological data has refined the understanding of the depositional palaeoenvironments of the Neill Klinter Group. In some cases, the boundaries of the palynological assemblage zones are congruent with major sequence stratigraphic surfaces and the palynological data thus support the sequence stratigraphic interpretation. In other cases, however, regional correlation indicates that the zone boundaries cross important sequence stratigraphic surfaces, such as sequence boundaries; such behaviour is thought to reflect the facies-dependent nature of certain of the palynological assemblage zones. The pattern of palynological events in East Greenland has also been recognised on the mid-Norwegian shelf.

Keywords: East Greenland, Jameson Land Basin, Lower-Middle Jurassic, Early Pliensbachian - early Aalenian, palynostratigraphy, sedimentology, sequence stratigraphic implications, regional correlation

E.B.K.* \& G.D.‡, Geological Survey of Denmark and Greenland, Geocenter Copenhagen, Øster Voldgade 10, DK1350 Copenhagen K, Denmark.

Present addresses: *Royal Tyrrell Museum of Palaeontology, Box 7500, Drumbeller TOJ OYO, Alberta, Canada. Email: evakoppelhus@hotmail.com

‡DONG A/S, Agern Allé 24-26, DK-2970 Hørsholm, Denmark.

The aim of this study was to obtain a better understanding of the palynomorph flora, the age and the depositional environment of the Neill Klinter Group in Jameson Land, East Greenland (Fig. 1). Although the sedimentology, fossil faunas, ichnofaunas, lithostratigraphy and sequence stratigraphy of this succession have been studied in detail (Rosenkrantz 1934; Sykes 1974; Dam 1990a, b, 1991; Dam \& Surlyk 1995, 1998), there are few published papers on the palynology of the Neill Klinter Group. The group has recently been divided into four formations and nine members (Fig. 2) and a detailed sequence stratigraphic correlation between East Greenland and Norway has been established (Dam \& Surlyk 1995, 1998). Lithostratigraphic units of the group that are precisely dated by macrofossils are restricted to the Rævekløft Formation and the Lepidopteriselv, 


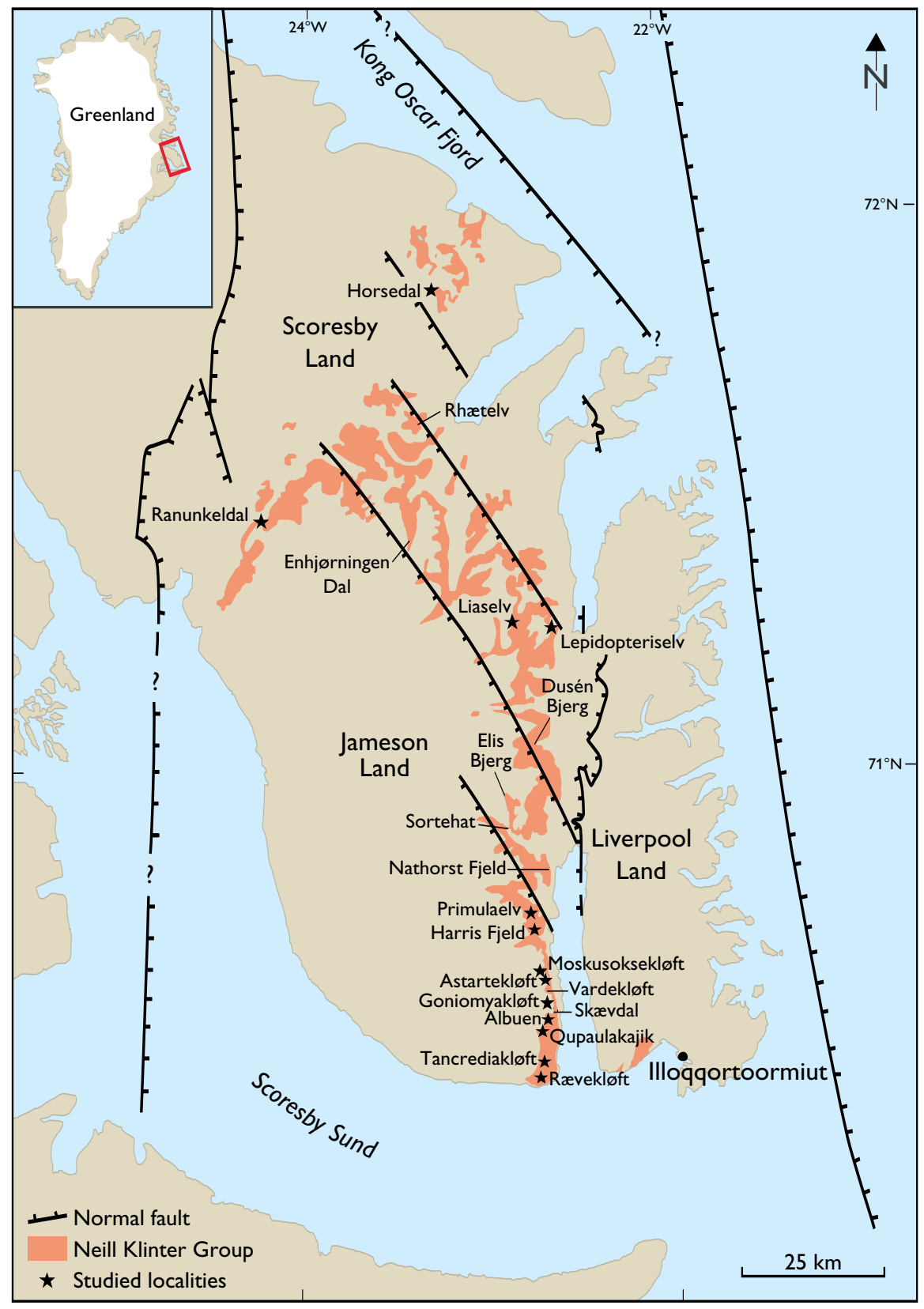

Fig. 1. Map of the Jameson Land region showing the outcrop of the Neill Klinter Group, the location of sections forming the basis of this study and additional localities mentioned in the text.

Nathorst Fjeld and Skæevdal Members of the Ostreaelv Formation. The Neill Klinter Group was sampled intensively for palynological analysis at a number of different localities in Jameson Land (Fig. 1). This paper only includes data from the lowermost three formations of the Neill Klinter Group (Rævekløft, Gule Horn and Ostreaelv Formations). The uppermost formation, the Sortehat Formation, is treated in an accompanying paper (Koppelhus \& Hansen 2003, this volume). Seven palynomorph assemblage zones have been established from the most complete section, at Albuen (Figs 3, 4). Data from other localities have been correlated with this section.

\section{Geological setting}

The Upper Palaeozoic - Mesozoic Jameson Land Basin is located in the present-day land areas of Jameson Land and Scoresby Land, at the southern end of the East Greenland rift system (Fig. 1; Surlyk 1978). This system is part of a larger rift complex separating Greenland from Norway before the opening of the North Atlantic Ocean (Ziegler 1988). The Jameson Land Basin is bounded to the east and west by major N-S-trending faults, and to the north by a NW-SE cross-fault in Kong Oscar Fjord (Surlyk 1977a, 1978, 1990a). The southern boundary is 


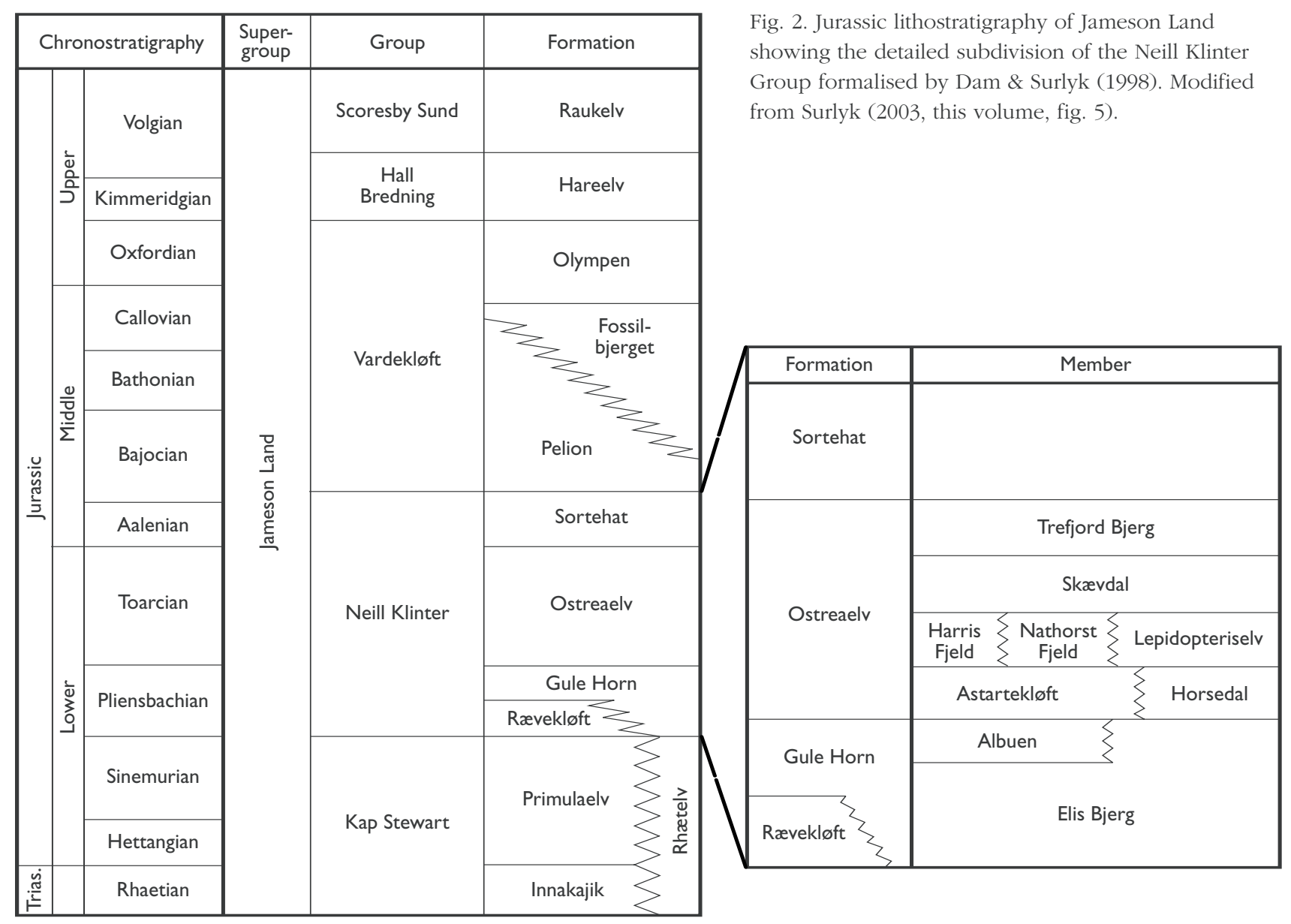

unknown, but the basin probably extended south of Scoresby Sund, an area that is now covered by Palaeogene plateau basalts. The basin was initiated in the Devonian due to extensional collapse of the over-thickened crust of the Caledonian mountain belt. The Devonian phase was probably associated with strike-slip or oblique-slip deformation resulting in the development of NW-SE-trending transverse faults in the north-eastern part of the basin. During Late Carboniferous - Early Permian times, the oblique-slip regime changed to a more orthogonal extensional regime, resulting in the development of basin margin half-grabens (Surlyk et al. 1984, 1986; Surlyk 1990a; Larsen \& Marcussen 1992). The period of extensional tectonics was followed by a long period of subsidence lasting from the Late Permian to the Cretaceous, interrupted by minor episodes of rifting and faulting (Surlyk 1977a, b, 1990a; Clemmensen 1980a; Surlyk et al. 1981, 1986; Larsen \& Marcussen 1992).

Triassic - Early Jurassic sedimentation in the Jameson Land Basin was, in addition to tectonic subsidence, also influenced by climate, drainage patterns and eustasy. During the Triassic - earliest Jurassic, a major lacustrine complex was situated in the Jameson Land Basin. The lacustrine deposits record a long-term change from a warm arid to a more temperate humid climate (Clemmensen 1978a, b, 1979, 1980a, b; Bromley \& Asgaard 1979; Dam \& Surlyk 1992, 1993). This long-term climatic change was mainly governed by a gradual northwards drift of the Laurasian continent and was accompanied by a long-term eustatic sea-level rise during the Early Jurassic. In the Pliensbachian, the lacustrine complex was transformed into a shallow marine embayment marking the first fully-marine inundation of the basin since Late Permian - Early Triassic times (Surlyk 1990b).

The sandstones and mudstones of the Neill Klinter Group were deposited in a wide, shallow tide- and storm-influenced marine embayment, during a period of relative tectonic quiescence. The facies pattern was controlled mainly by relative sea-level fluctuations, sediment influx and basinal currents (Sykes 1974; Dam \& Surlyk 1995, 1998). 


\section{Stratigraphy}

The Pliensbachian - lower Aalenian succession now referred to the Neill Klinter Group was initially described by Rosenkrantz (1929), but was first formally established as a formation by Surlyk et al. (1973). The Neill Klinter Formation (sensu Surlyk et al. 1973) has subsequently been raised to group status (Dam \& Surlyk 1998) and the Rævekløft, Gule Horn and Ostreaelv Members of Surlyk et al. (1973) have been elevated to formation status. Moreover, the former Sortehat Member of the Vardekløft Formation (Surlyk et al. 1973) has been promoted to formation and transferred to the Neill Klinter Group (Dam \& Surlyk 1998). These authors divided the Gule Horn Formation into two new members and the Ostreaelv Formation into seven new members (Fig. 2).

The Neill Klinter Group is exposed in Jameson Land and Scoresby Land, and in a small fault-bounded outlier in the southern part of Liverpool Land (Fig. 1); it is $300-450 \mathrm{~m}$ thick. The boundary between the Kap Stewart Group and the succeeding Neill Klinter Group is an erosional unconformity along the south-eastern basin margin, representing a major hiatus corresponding to the Sinemurian Stage (Harris 1931; Surlyk 1991; Dam \& Surlyk 1995, 1998). The unconformity passes basinwards into a conformity and the contact between the lacustrine mudstones of the Kap Stewart Group and the shallow marine sandstones of the Neill Klinter Group is gradational (Fig. 5; Surlyk 1991; Dam \& Surlyk 1995, 1998). The upper boundary of the Neill Klinter Group is placed at a sharp unconformity between the mudstones of the Sortehat Formation and the sandstones of the Vardekløft Group (Surlyk et al. 1973; Surlyk 1990a; Engkilde 1994; Koppelhus \& Hansen 2003, this volume). The Neill Klinter Group and most of its constituent formations and members show an overall sheet geometry, although the thicknesses of the units are greatest in the basin centre and thin towards the margins (Dam \& Surlyk 1995, 1998).

A rich marine fauna is present in the lower part of the Neill Klinter Group (Rosenkrantz 1934). It occurs in the Rævekløft Formation and is restricted to certain levels separated by largely unfossiliferous intervals. Rosenkrantz (1934) identified a lower division, with a diverse fauna (150 species) dominated by bivalves, gastropods, cephalopods, echinoids and crinoids, and an upper division yielding a relatively sparse fauna (c. 20 molluscan species). Ammonites of the genus Uptonia occur in the lower division, suggesting that these beds belong to the Early Pliensbachian Jamesoni Zone
(Rosenkrantz 1934). In the upper division, Rosenkrantz (1934) found two ammonites, Beaniceras sp. and Lytoceras fimbriatum. Rosenkrantz (1934) referred this division to the Ibex Zone, although the bed also yielded an ammonite that appears to be Aegoceras aff. capricornus of the maculatum group, indicative of the Davoei Zone (Callomon 1961; Surlyk et al. 1973). All the belemnites recovered from the Rævekløft Formation by Rosenkrantz were apparently collected from the Jamesoni Zone interval. They indicate that the Jamesoni Zone as adopted by Rosenkrantz (1934) includes the Early Pliensbachian Jamesoni Zone to at least the Ibex Zone and possibly the early Davoie Zone (Doyle 1991).

The marine macrofossils of the Lepidopteriselv, Nathorst Fjeld, Skævdal and Trefjord Bjerg Members of the Ostreaelv Formation and the Sortehat Formation are bivalves, brachiopods, crinoids, belemnites, ammonites, and vertebrates (Rosenkrantz 1934). Ammonites collected on the top of Elis Bjerg from strata belonging to the Lepidopteriselv Member include Dactylioceras semicelatum (Simpson) sensu Howarth 1992 (probably including D. groenlandicum Rosenkrantz 1934) and Hildaites sp. aff. murleyi (Moxon). Dactylioceras semicelatum belongs to the Early Toarcian Tenuicostatum Zone, Semicelatum Subzone (J.H. Callomon, personal communication 1993). Hildaites sp. is an early form, reminiscent of Protogrammoceras. Dactylioceras sp. has also been collected at Nathorst Fjeld in the Nathorst Fjeld Member and in the lower part of the Skævdal Member, also suggesting an Early Toarcian Tenuicostatum Zone age (C. Bjerrum and J.H. Callomon, personal communications 1996). Dactylioceras sp. and Hildaites sp., suggestive of the Early Toarcian, have also been collected from the Lepidopteriselv Member in Horsedal, although they were both loose specimens. Phydoleoceras sp. has been collected on Nathorst Fjeld in the Trefjord Bjerg Member, just beneath the boundary of the Sortehat Formation (C. Bjerrum, personal communication 1996).

The Lepidopteriselv Member has been correlated on sequence stratigraphic grounds with the Nathorst Fjeld Member (Dam \& Surlyk 1995, 1998). On Nathorst Fjeld, Rosenkrantz (1934) collected a specimen of the belemnite Parapassolotheuthis polita at an altitude of $494 \mathrm{~m}$, and 'Parabrachybelus' subaduncatus at $509 \mathrm{~m}$. The lower level probably belongs to the Nathorst Fjeld Member, and the upper level to the overlying Skævdal Member. The two species have restricted ranges and are not known to be widespread in Europe. Parapassolotheuthis polita has only been recorded from the Early Toarcian latest Falciferum Zone or earliest Bifrons Zone (Commune Subzone) in Britain, while Para- 
brachybelus' subaduncatus, which so far has only been recorded from mainland Europe, has a range probably restricted to the latest Toarcian Levesquei Zone (Doyle 1991). The ammonite Dactylioceras semicelatum (Simpson) has been collected at the base of the Skævdal Member at Nathorst Fjeld (C. Bjerrum, personal communication 1996) and in the Lepidopteriselv Member on top of Elis Bjerg indicating an Early Toarcian Tenuicostatum Zone, Semicelatum Subzone age (J.H. Callomon, personal communication 1993). Based on these data, the Nathorst Fjeld and Lepidopteriselv Members and the lower part of the Skæevdal Member include strata with an Early Toarcian Tenuicostatum Zone to latest Falciferum Zone or earliest Bifrons Zone age. Belemnites suggest that the Skævdal Member may also include strata with a latest Toarcian Levesquei Zone age (Doyle 1991; Dam \& Surlyk 1998), suggesting either that the Skæevdal Member has a very long age range, that the belemnites cannot be used stratigraphically or that the D. semicelatum at the base of the Skævdal Member is reworked.

Dam \& Surlyk $(1995,1998)$ interpreted the Neill Klinter Group within a sequence stratigraphic framework and attempted a sequence stratigraphic correlation with the coeval Tilje, Ror, Ile and Not Formations on the midNorwegian shelf. This comparison demonstrated that the Lower Jurassic in both regions consists of six sequences and it appears feasible to directly correlate systems tracts on a scale of a few tens of metres between East Greenland and the mid-Norwegian shelf (see Fig. 17).

\section{Previous palynological work}

Previous reports on the palynology of the Neill Klinter Group have been published by Lund \& Pedersen (1985) and Underhill \& Partington (1994). The former authors studied the Neill Klinter Group together with the overlying Vardekløft Group (sensu Surlyk 2003, this volume, fig. 5) and the lower part of the Hareelv Formation. Based on material collected from Vardekløft, in the south-eastern part of the basin (Fig. 1), Lund \& Pedersen (1985) proposed four assemblage zones for the entire succession based on the miospore assemblages. Dinoflagellate cysts were used to improve the age correlation of the spore-pollen assemblages. The three lowermost assemblage zones A, B and C of Lund \& Pedersen (1985) cover the Rævekløft, Gule Horn and Ostreaelv Formations of the Neill Klinter Group. Assemblage Zone A is divided into subassemblages A1 and A2; the age of the zone was suggested to be Late
Pliensbachian because of the presence of the spore Kraeuselisporites reissingeri and the dinoflagellate cyst Nannoceratopsis triceras. Assemblage Zone B is characterised by abundant Spheripollenites subgranulatus and Luehndea spinosa, and an Early Toarcian age was proposed. Assemblage Zone $\mathrm{C}$ is characterised by the incoming of the pollen Callialasporites dampieri, the spores Sestrosporites pseudoalveolatus and Staplinisporites caminus and the dinoflagellate cyst Parvocysta contracta (now Susadinium scrofoides); these species were considered to indicate a Late Toarcian age for the lowermost Assemblage Zone C (subassemblage (C)).

Underhill \& Partington (1994) discussed the development of the Lower Jurassic in East Greenland in connection with a sequence stratigraphic study of the North Sea. They included 3 sections from Jameson Land, Section 1 from Liaselv, Section 2 from Vardekløft and Section 3 from the Harris Fjeld/Primulaelv area (Fig. 1). Sections 1 and 2 cover the uppermost few metres of the Ostreaelv Formation and all of the Sortehat Formation and Vardekløft Group. Section 3 covers $170 \mathrm{~m}$ of the Neill Klinter Group. Underhill \& Partington (1994) analysed 48 samples and recognised 11 events. They suggested a Late Pliensbachian - earliest Toarcian age for the Gule Horn Formation and a Toarcian age for the Ostreaelv Formation.

\section{Materials and methods}

Most of the samples used in this study are from the section at Albuen, in the fifth ravine north of Skævdal (Figs $1,3)$. Intervals that proved inaccessible in this ravine were sampled at Astartekløft (see Figs 1, 9). Samples were also obtained from Rævekløft, Tancrediakløft, Qupaulakajik, Albuen, Goniomyakløft, Astartekløft, Moskusoksekløft, Harris Fjeld, Primulaelv, Lepidopteriselv, Liaselv, Horsedal and Ranunkeldal (Fig. 1). A number of samples collected by Claus Heinberg and Tove Birkelund in 1974 from Lepidopteriselv were also included in the study.

The samples were processed for their palynological content using the techniques adopted at the former Geological Survey of Greenland, as described by Nøhr-Hansen (1993). Over 210 samples were analysed for their palynological content by means of a transmission light microscope. Two hundred specimens were counted in each sample and all species were registered in the range chart programme SIS and on the video database at the Geological Survey of Denmark and Greenland, where the slides are stored. 

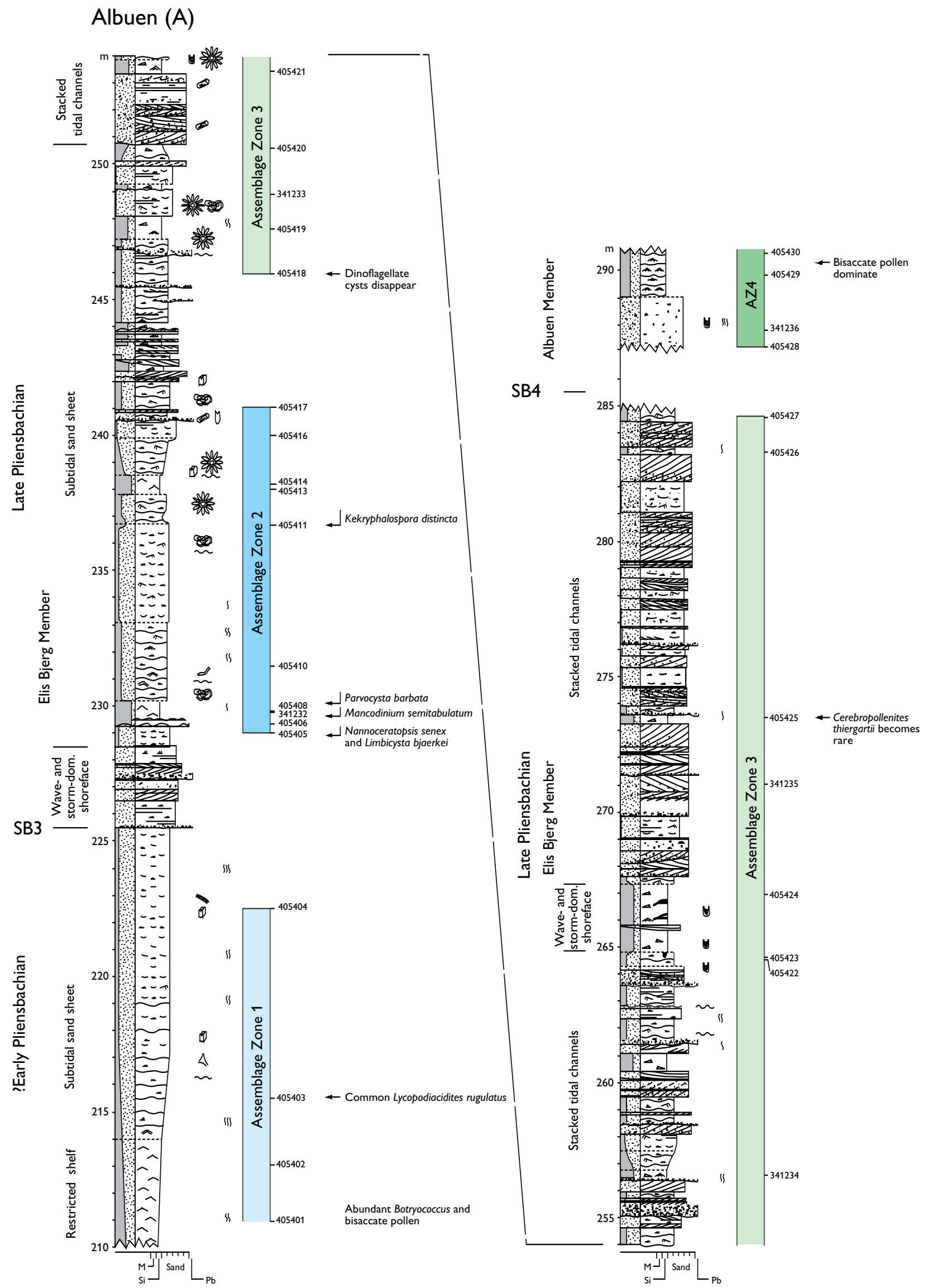


\section{Legend to sedimentary logs}

\section{Lithology}

Mudstone

$\because \because \therefore$ Sandstone

Pebbly sandstone

Coal

$\$$ Volcanic intrusive

$\bigodot$ Concretion

$\therefore \because$ Siderised rip-up mudstone

clasts/conglomerate

$0: 0$
0 Conglomerate (qz, quartzite clasts)

Bed contacts

$\sim$ Sharp/erosive or irregular

Sharp/planar

- - Gradational
Biota

S Rootlets

P Plant fragments

$\Leftrightarrow$ Drifted plant stems/logs

Bivalves

\& Gastropods

(2) Ammonites

Y Belemnites

(1) Brachiopods

国 Crinoids

Echinoderms
Trace fossils

S Weak

SS Moderate bioturbation

$\iiint_{\text {Intense }}$

U Arenicolites isp.

(2) Curvolithos multiplex

(-) Diplocraterion parallelum

Gyrochorte comosa

Helminthopsis isp.

$\nabla$ Monocraterion isp.

Ophiomorpha nodosa

Phoebichnus trochoides

Planolites beverleyensis

of Taenidium serpentinum

8. Teichichnus isp.

$\bigwedge$ Thalassinoides isp.

$\sim$ Unidentified sinuous horizontal burrow

Nave ripple cross-lamination

Cross-bedding with pebbles along foresets

Structureless

Structureless

(with quartzite pebbles)

S(同) Slumping

Cross-lamination

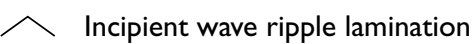

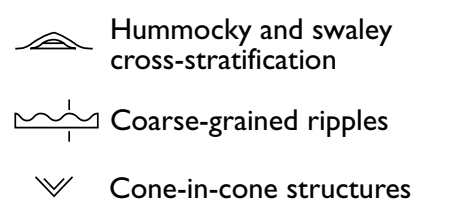

\section{Planar cross-bedding \\ Trough cross-bedding \\ $\triangle \Delta$ Lenticular bedding \\ $D$ Wavy bedding \\ $\smile$ Flaser bedding \\ Sedimentary features}

Fig. 3A-C. Sedimentological logs through the Gule Horn $(\mathbf{A}, \mathbf{B})$ and Ostreaelv (B, C) Formations, Neill Klinter Group, at Albuen (for location, see Fig. 1); the Gule Horn Formation comprises the Elis Bjerg and Albuen Members, the Ostreaelv Formation is composed of the Astartekløft, Nathorst Fjeld, Skævdal and Trefjord Bjerg Members. Sequence boundaries (SB3-7), palynomorph assemblage zones (AZ) and sample numbers are indicated. The legend accompanying this figure is also applicable to Figs 5, 7,9 and 15. 

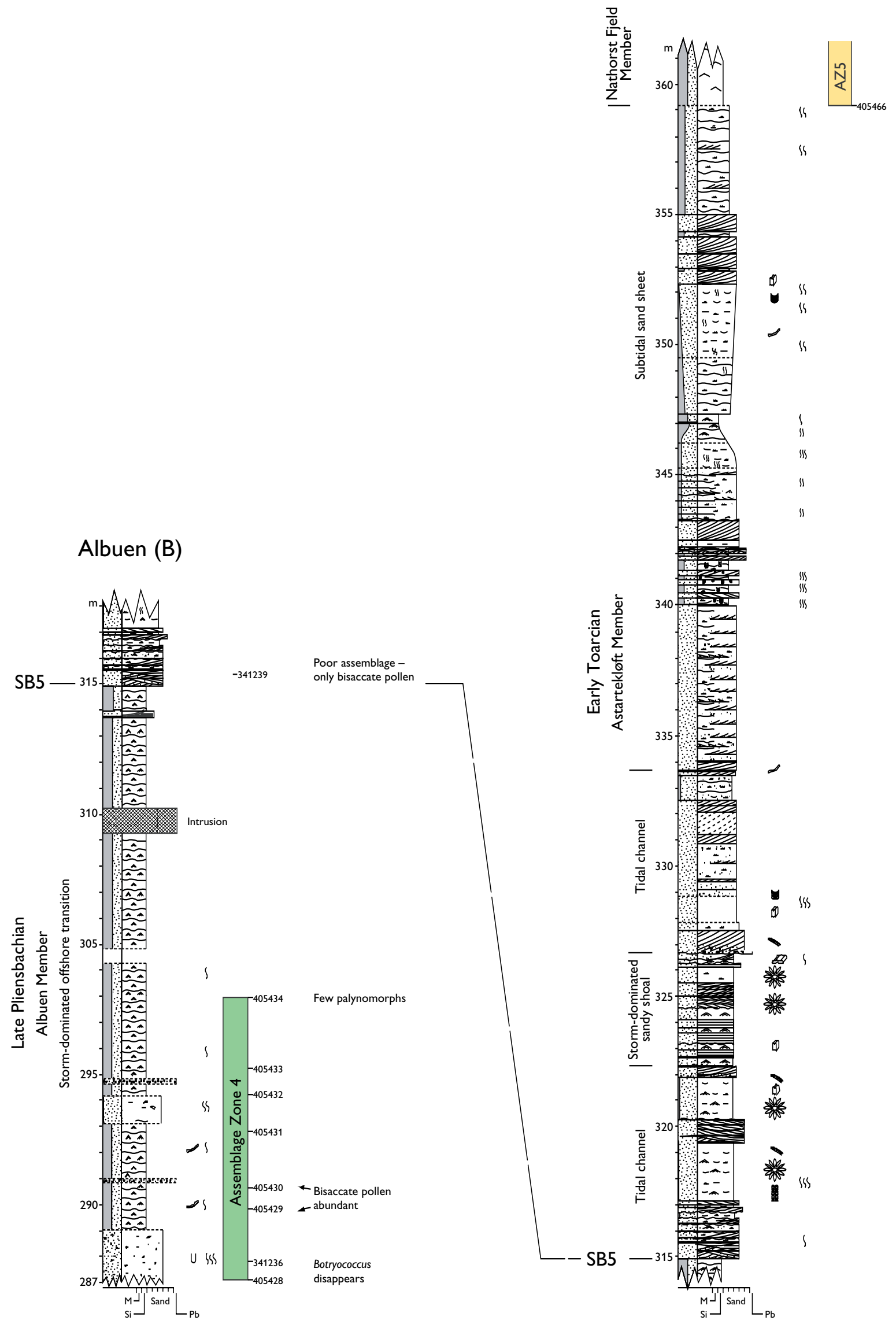


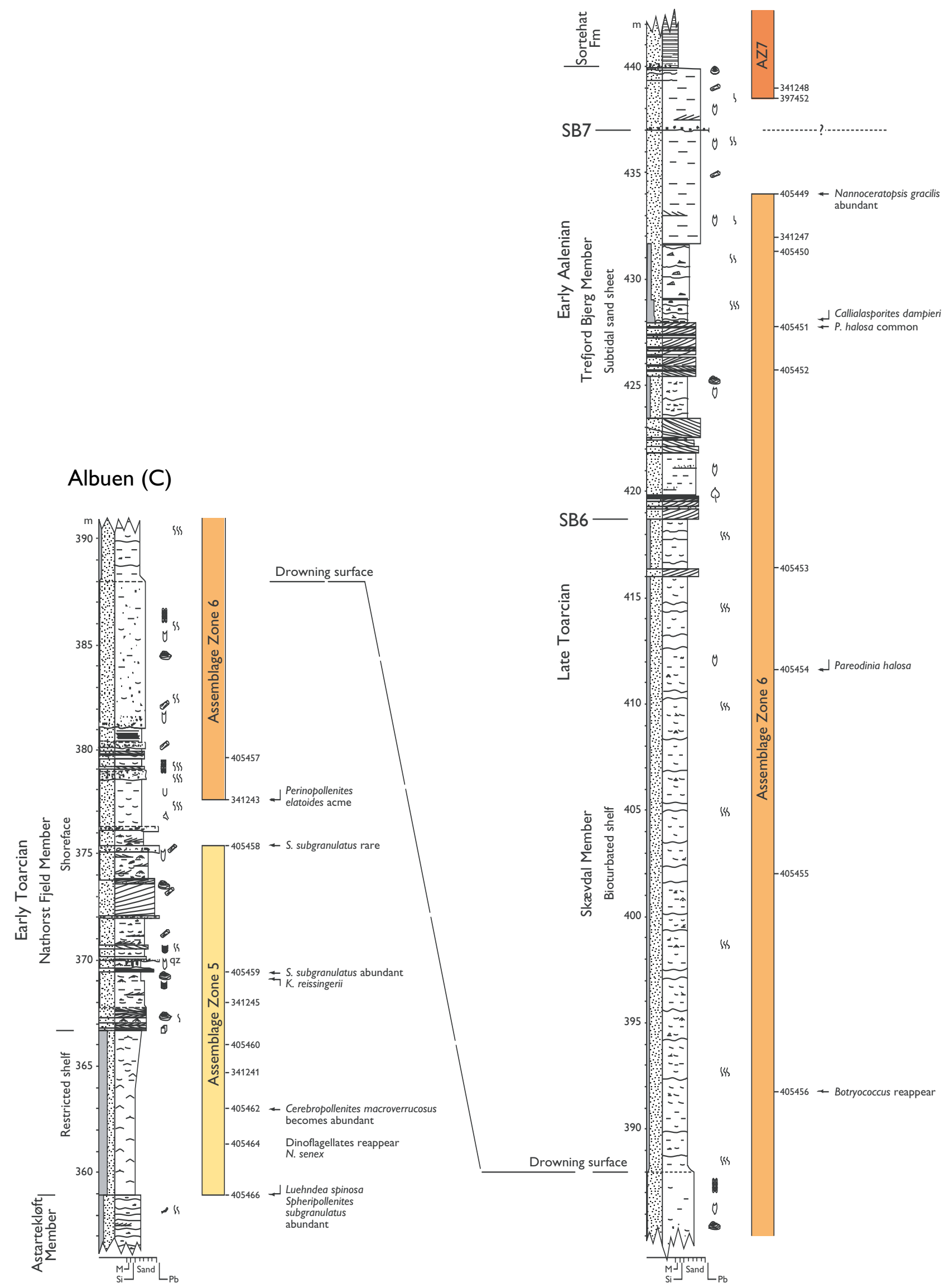




\section{Palynological zones: definition}

Nine assemblage zones have been recognised in the Neill Klinter Group. The zones are based on the composition of the entire assemblage of spores, pollen, dinoflagellate cysts, acritarchs and freshwater algae. The assemblage zones are numbered 1-9 and named after the species which dominate the assemblages. Assemblage Zones 1-6 are defined and described in detail in this paper, together with a brief description of Assemblage Zone 7 . Assemblage Zones 7-9 are formally defined in the accompanying paper on the Sortehat Formation (Koppelhus \& Hansen 2003, this volume). The recorded taxa are listed in full in Appendix 1 and the important species are illustrated in Plates 1-7.

The most complete section was sampled at Albuen (Figs 1, 3); approximately 70 samples were analysed for palynomorphs from this section (Fig. 4, facing page 744). These samples yielded rich though not very wellpreserved palynomorph assemblages (Plates 1-7), with the exception of samples taken close to the Palaeogene sills and dykes that penetrate the sedimentary succession. These samples were either barren or the palynomorphs present were so dark as to be indeterminate. From the productive samples, approximately 150 species of spores, pollen, dinoflagellate cysts, acritarchs and freshwater algae were identified (Appendix 1). The intensively sampled Albuen section forms the reference section for Assemblage Zones 1-6 defined in this paper; Assemblage Zones 7-9 are defined from the borehole at Sortehat (Fig. 1; Koppelhus \& Hansen 2003, this volume). In addition to the Albuen reference section, important data for the definition of the assemblage zones were obtained from Ranunkeldal, Goniomyakløft and Astartekløft (Fig. 1).

In addition to the formal assemblage zones defined here, a distinctive palynological assemblage was identified in samples from the Horsedal Member of the Ostreaelv Formation at Horsedal. This assemblage is defined as the Deltoidospora Assemblage (see below under the Horsedal locality).

\section{Assemblage Zone 1: Cerebropollenites thiergartii - Pinuspollenites minimus - Botryococcus}

new assemblage zone

$\begin{array}{lll}\text { Occurrence. } & \text { Albuen } & 211-222.5 \mathrm{~m} \\ & \text { Goniomyakløft } & 226.5 \mathrm{~m} \text { (single sample) }\end{array}$

$$
\begin{array}{ll}
\text { Primulaelv } & 310 \mathrm{~m} \text { (single sample) } \\
\text { Rævekløft } & 118-122 \mathrm{~m} \\
\text { Ranunkeldal } & 306-352.5 \mathrm{~m}
\end{array}
$$

This assemblage zone was recorded from the Rævekløft Formation at Rævekløft and Goniomyakløft and from the Elis Bjerg Member (Gule Horn Formation) at Albuen, Primulaelv and Ranunkeldal. Relative to the sequence stratigraphic scheme of Dam \& Surlyk $(1995,1998)$, the assemblage occurs within sequences SQ1 and SQ2 (see Fig. 17).

Reference section. Albuen, 211 m (sample 405401) 222.5 m (sample 405404; Figs 1-4).

Additional section. Ranunkeldal, 306 m (sample 341171) - $352.5 \mathrm{~m}$ (sample 341173; Figs 5, 6).

Base. The base is not seen in the reference section at Albuen (Figs 3A, 4). At Ranunkeldal, the base of the zone is placed at sample 341171, immediately above the base of the Neill Klinter Group (Figs 5, 6); samples from the underlying Kap Stewart Group are considered to represent a different assemblage but further work is required to precisely define the base of Assemblage Zone 1.

Top. The top of the zone is defined by the last sample showing this assemblage (sample 405404 at $222.5 \mathrm{~m}$ at Albuen) beneath the first appearance of Nannoceratopsis senex and $N$. sp. (Figs 3A, 4).

Characteristics. Terrestrial palynomorphs (spores and pollen) dominate together with Botryococcus sp. The most common spores are Deltoidospora sp. and Baculatisporites sp., and the pollen is dominated by Cerebropollenites thiergartii and Pinuspollenites minimus and other bisaccates. Other characteristic species are Cerebropollenites macroverrucosus, Chasmatosporites bians and C. major. No dinoflagellate cysts have been determined with certainty, but a few acritarchs were identified. The freshwater alga Botryococcus sp. occurs in abundance.

Suggested age. An Early Pliensbachian age is proposed based on the presence of abundant Cerebropollenites thiergartii.

Palaeoenvironment. The assemblage records a strong terrestrial signal, most components being indicative of freshwater to brackish conditions. Botryococcus, for 
Ranunkeldal

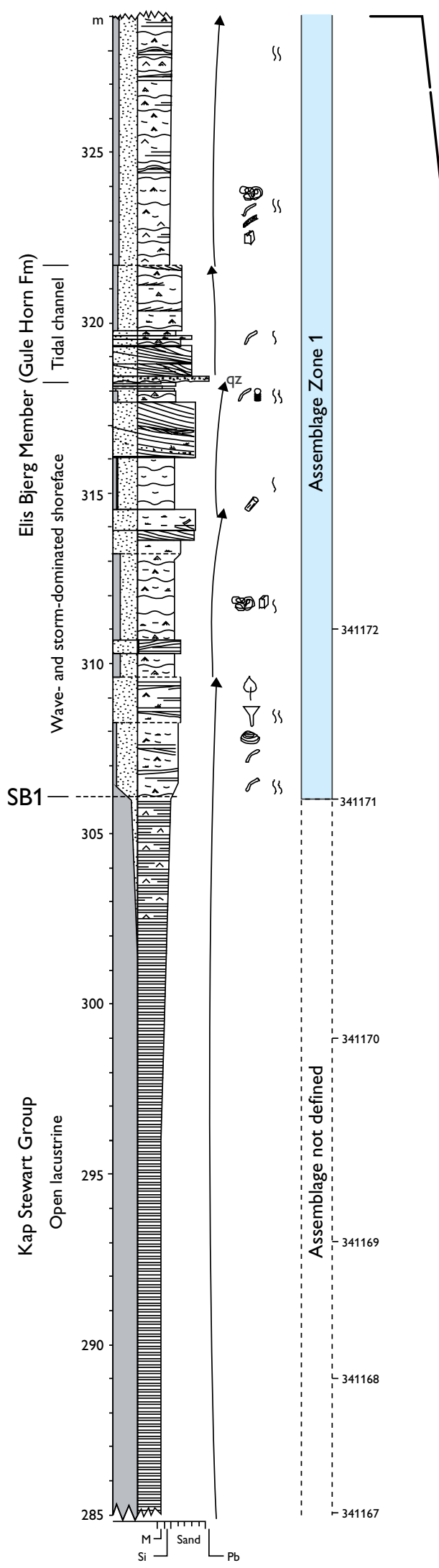

Fig. 5. Sedimentological log through the uppermost part of the Kap Stewart Group and the Elis Bjerg Member (Gule Horn Formation) of the Neill Klinter Group in Ranunkeldal (for location, see Fig. 1). Sequence boundary (SB1), palynomorph Assemblage Zone 1 and sample numbers are indicated. For legend, see Fig. 3; arrows denote grainsize trends.

ss

(1)

ss

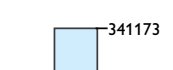

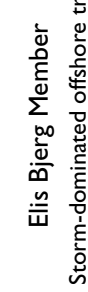

ss

in

345

350 and
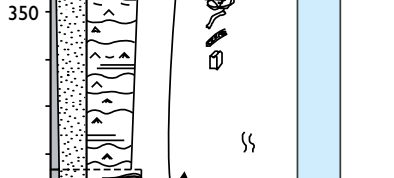

(1)

S 4

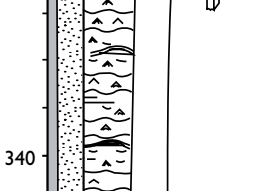

踏

厸

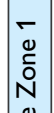

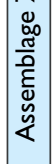

Ss

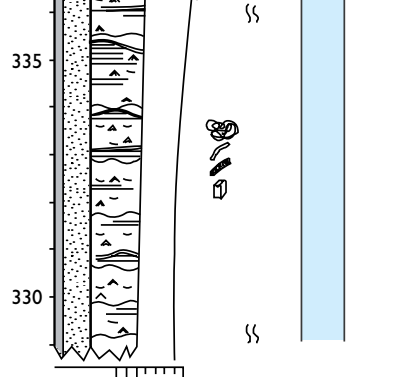




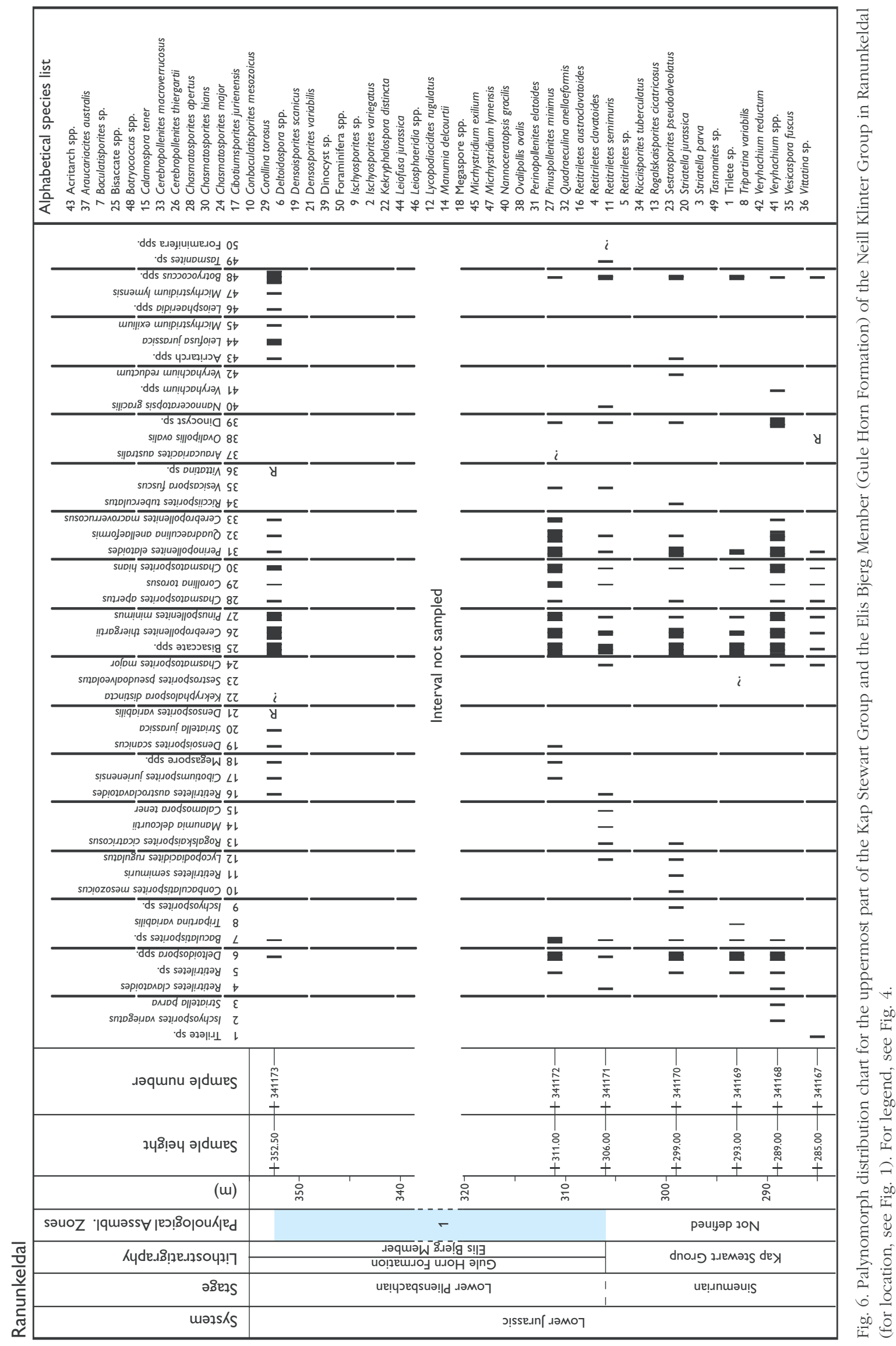


example, is a planktonic green alga that occurs in colonies. It is known to adapt to different aquatic environments (fresh to brackish water), has been recorded from tropical to subarctic regions and has a stratigraphic range from the Precambrian to the present day (Guy-Ohlson 1992). When large numbers of Botryococcus are recorded, it indicates that the depositional environment was strongly influenced by fresh or brackish waters (Guy-Ohlson 1992).

Remarks. Assemblage Zone 1 is equivalent to Assemblage Zone A of Lund \& Pedersen (1985), and probably to the lower part of section 3 of Underhill \& Partington (1994). The assemblage is similar but not identical to that described from the Chasmatosporites Zone (miospore) and the Mendicodinium reticulatum Zone (dinoflagellate) from the successions of Bornholm and the Øresund area (Koppelhus \& Nielsen 1994; Koppelhus \& Batten 1996).

\section{Assemblage Zone 2: Nannoceratopsis-Botryococcus}

new assemblage zone

\begin{tabular}{|c|c|c|}
\hline \multirow[t]{5}{*}{ Occurrence. } & Albuen & $229-241 \mathrm{~m}$ \\
\hline & Goniomyakløft & $229.8-235 \mathrm{~m}$ \\
\hline & Lepidopteriselv & $638-654 \mathrm{~m}$ \\
\hline & Liaselv & $293-325 \mathrm{~m}$ \\
\hline & Rævekløft & $208-210 \mathrm{~m}$ \\
\hline
\end{tabular}

This assemblage zone is characteristic of the Elis Bjerg Member of the Gule Horn Formation where it typically occurs within sequence SQ3 of Dam \& Surlyk (1995, 1998), for example at Albuen (Figs 3A, 4), Lepidopteriselv, Liaselv and Rævekløft. At Goniomyakløft, however, Assemblage Zone 2 was identified in the uppermost Rævekløft Formation and the lowermost Elis Bjerg Member (Figs 7, 8), within sequence SQ2 of Dam \& Surlyk $(1995,1998)$.

Reference section. Albuen, 229 m (sample 405405) $241 \mathrm{~m}$ (sample 405417; Figs 3A, 4).

Additional section. Goniomyakløft, $229.8 \mathrm{~m}$ (sample 405469) - 235 m (sample 405471; Figs 7, 8).

Base. The base of the zone is defined by the sample showing the first appearance of Nannoceratopsis senex and $N$. sp.

\section{Goniomyakløft}

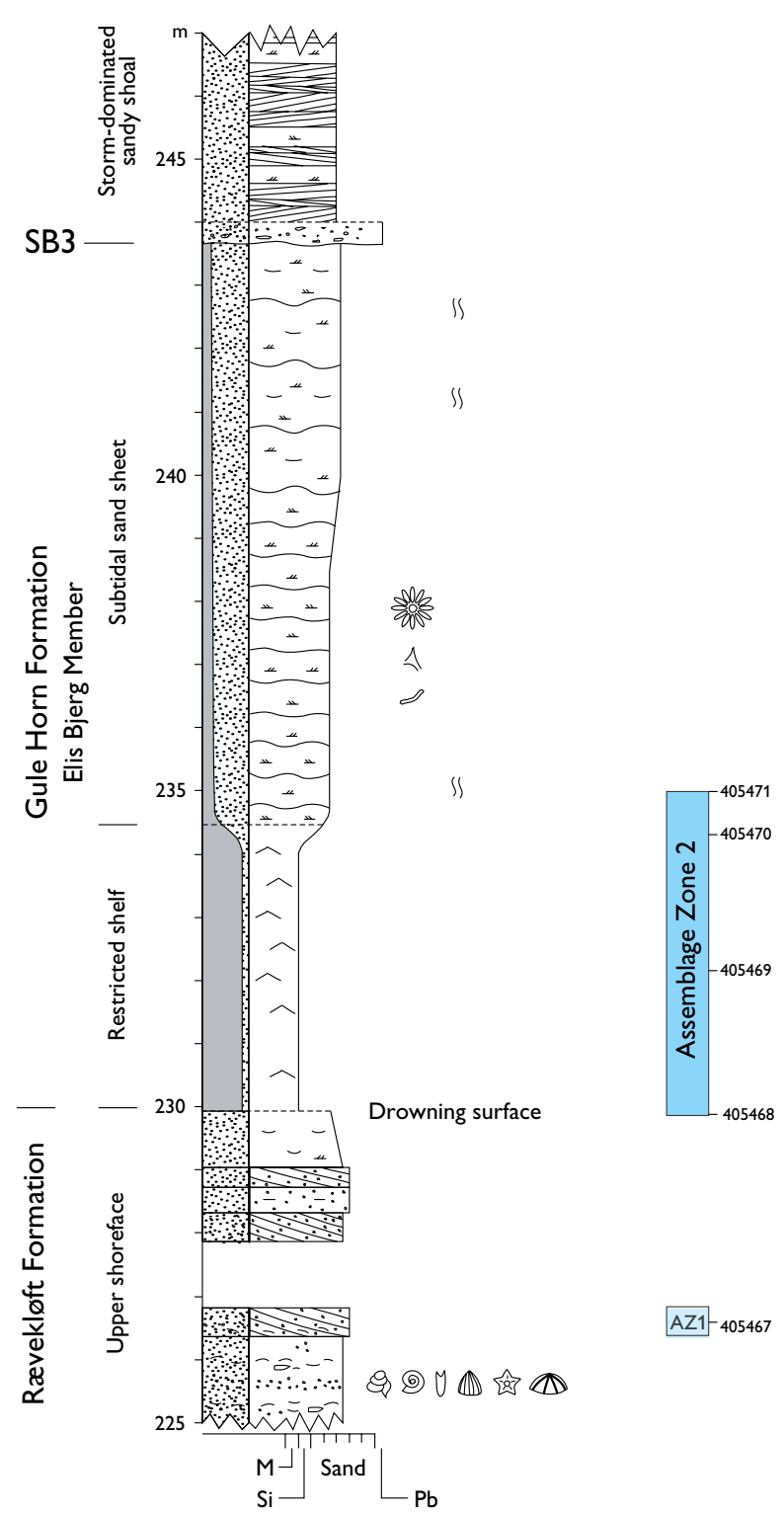

Fig. 7. Sedimentological log through the uppermost part of the Rævekløft Formation and the Elis Bjerg Member (Gule Horn Formation) at Goniomyakløft (for location, see Fig. 1). Sequence boundary (SB3), palynomorph assemblage zones (AZ) and sample numbers are indicated. For legend, see Fig. 3. Note that the exact location of sample 405467 is uncertain due to imprecise field records; although here placed immediately beneath the nonexposed interval (226.5-227.8 m), it is possible that it derives from immediately above this interval. For legend, see Fig. 3.

Top. The top of the zone is defined by the last sample showing this palynomorph assemblage, above which Nannoceratopsis disappears together with most other dinoflagellate cysts. 


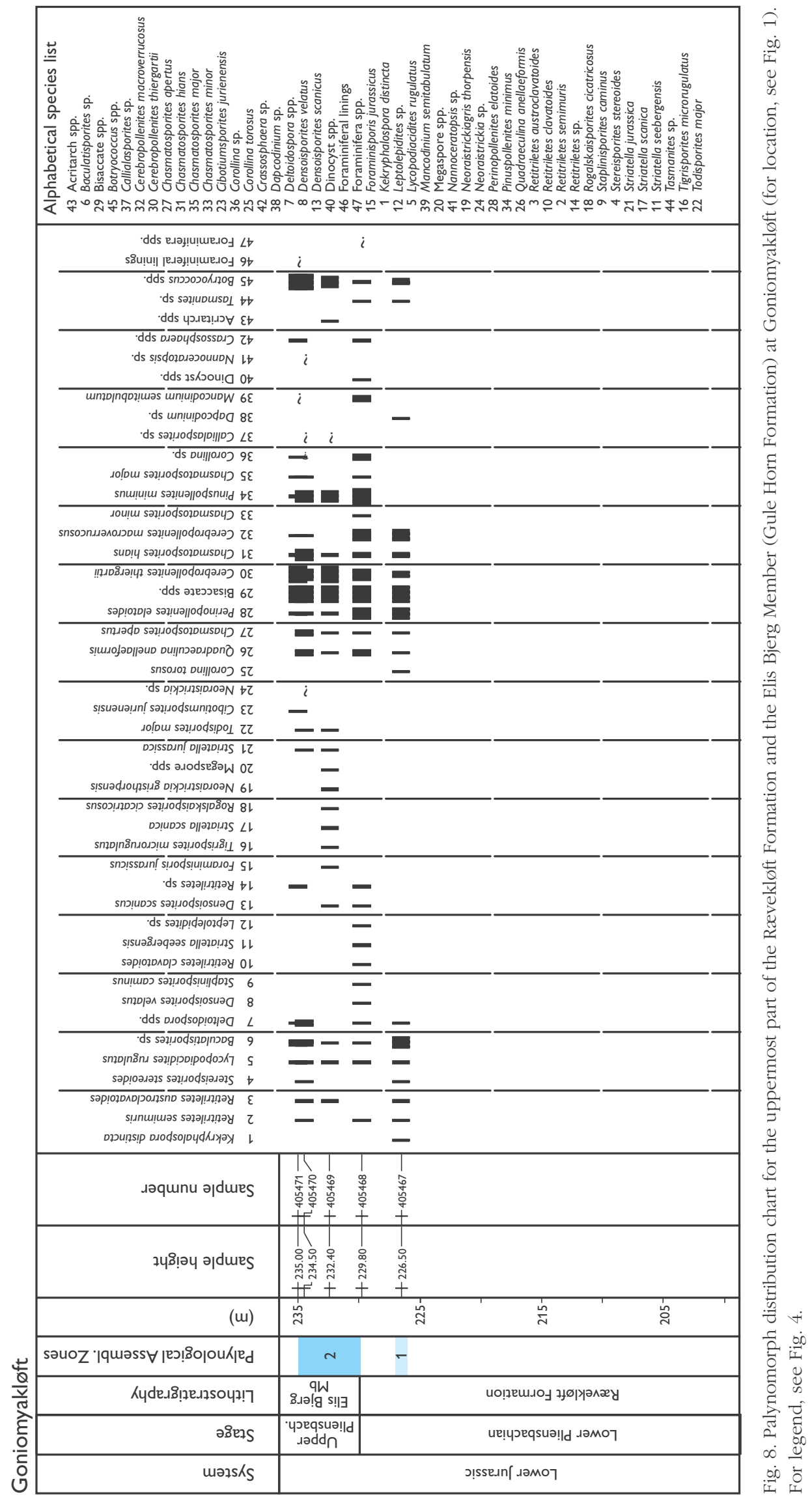


Characteristics. Terrestrial palynomorphs dominate the assemblage together with Botryococcus sp., as in Assemblage Zone 1; the spore Kekryphalospora distincta appears for the first time. The difference between this assemblage and that of Assemblage Zone 1 is the appearance of dinoflagellate cysts, including Mancodinium semitabulatum, Nannoceratopsis senex, N. gracilis, $N$. plegas, $N$. triangulata and Parvocysta barbata and the presence of more acritarchs, including Limbicysta bjaerkei.

Suggested age. A Late Pliensbachian age is suggested based on the first appearance of the spore Kekryphalospora distincta in sample 405411 (236.50 m) in the Albuen section (Fig. 3A); this species is known to have a range from Late Pliensbachian to Early Bajocian (Fenton \& Riding 1987).

Palaeoenvironment. Although influenced by brackish to marine waters, there is still a strong terrestrial signal.

Remarks. The spore Kekryphalospora distincta is also known from assemblages of Pliensbachian age from the Danish area (Anholt borehole, Øresund borehole 15 and the Korsodde section on Bornholm; Seidenkrantz et al. 1993; Koppelhus \& Nielsen 1994; Koppelhus \& Batten 1996). The appearance of Nannoceratopsis triangulata is particularly noteworthy as this species has previously only been recorded from NW Germany where it occurs in the uppermost Toarcian (Prauss 1987). The appearance of Limbicysta bjaerkei and Parvocysta barbata is unexpected at this level, as they are known to have their first appearance in the Bifrons Zone (late Early Toarcian) in the North Sea and Svalbard and on the mid-Norwegian shelf (Bjærke 1980a; Riding \& Thomas 1992; I. Throndsen, personal communication 1996). However, these anomalous occurrences were also recognised at this level in the Neill Klinter Group by Underhill \& Partington (1994); L. bjaerkei was recorded in their section 3 between $360 \mathrm{~m}$ and $370 \mathrm{~m}$. Two explanations are possible: either P. barbata and $L$. bjaerke $i$ have a longer range than recently reported or the sediments are younger than expected.

In Assemblage Zone 2, acritarchs are more common than in the underlying zone and in the succeeding zones; this pattern is known from the Lower Jurassic in England and Wales (Wall 1965).

\section{Assemblage Zone 3: \\ Chasmatosporites - Cerebropollenites thiergartii - Botryococcus}

new assemblage zone

$\begin{array}{lll}\text { Occurrence. } & \text { Albuen } & 246-284.7 \mathrm{~m} \\ & \text { Astartekløft } & 266-328 \mathrm{~m} \\ & \text { Lepidopteriselv } & 674-700 \mathrm{~m}\end{array}$

Assemblage Zone 3 is confined to the uppermost part of the Elis Bjerg Member (Gule Horn Formation) in the Albuen and Lepidopteriselv sections; relative to the sequence stratigraphic scheme of Dam \& Surlyk (1995, 1998), the assemblage occurs within the upper levels of sequence SQ3, below sequence boundary SB4 in these sections (Fig. 3A). At Astartekløft, however, the assemblage spans the boundary between the Elis Bjerg Member and the succeeding Albuen Member, thus straddling the sequence boundary (SB4) between sequences SQ3 and SQ4 (Fig. 10). It should be noted, however, that recognition of assemblage Zone 3 is based on only two widely spaced samples at the Astartekløft locality (Fig. 10).

Reference section. Albuen, 246 m (sample 405418) $284.7 \mathrm{~m}$ (sample 405427; Figs 3A, 4).

Additional section. Astartekløft, 266 m (sample 346614) - 328 m (sample 346627; Fig. 10)

Base. The base is placed at the first sample in which dinoflagellate cysts are absent or rare, succeeding samples of Assemblage Zone 2 characterised by a number of dinoflagellate species.

Top. The top of the assemblage is placed at the last sample showing the assemblage described below; above this level, the palynomorph assemblage is dominated by bisaccate pollen.

Characteristics. This zone is also dominated by terrestrial material. A number of spores have their first appearance, such as Striatella jurassica, Kraeuselisporites reissingeri, Taurocusporites verrucatus and Densoisporites velatus. The pollen species and Botryococcus sp. are very consistent; only few dinoflagellate cysts and acritarchs were recorded.

Suggested age. A Late Pliensbachian age is proposed based on the absence of marker species indicative of 
a younger age. The miospore assemblage is a continuation of Assemblage Zone 2.

Palaeoenvironment. The palynology displays an overwhelmingly terrestrial signal; there is very little evidence of marine influence.

Remarks. Cerebropollenites thiergartii is common through much of the zone but becomes rare towards the top of the zone and in succeeding zones.

\section{Assemblage Zone 4: Bisaccates}

new assemblage zone

$\begin{array}{lll}\text { Occurrence. } & \text { Albuen } & \text { 287-297.8 m } \\ \text { Astartekløft } & 339-340 \mathrm{~m}\end{array}$

This assemblage zone is restricted to the Albuen Member (Gule Horn Formation) at both Albuen and Astartekløft (Figs 3A, 3B, 4, 9, 10); it thus falls within sequence SQ4 of Dam \& Surlyk (1995, 1998).

Reference section. Albuen, 287 m (sample 405428) 297.8 m (sample 405434; Figs 3A, 3B, 4).

Additional section. Astartekløft, 339 m (sample 405472) - 340 m (sample 405473; Figs 9, 10).

Base. The base is defined by the first sample dominated overwhelmingly by bisaccate pollen, to the exclusion of most other palynomorphs.

Top. The top of the zone is defined by the last sample composed predominantly of bisaccate pollen; the succeeding sample, defining the base of the overlying Assemblage Zone 5, is characterised by the first appearance of Spheripollenites subgranulatus.

Characteristics. This assemblage zone is characterised by very poor preservation of the few palynomorphs present and by the absence of marine palynomorphs. Bisaccate pollen are common in most of the samples. The spores, pollen and Botryococcus sp. that were abundant in the Assemblage Zones 1-3 are absent in this zone.

Suggested age. A Late Pliensbachian age is assigned to this zone, as for Assemblage Zone 3 (see above).
Palaeoenvironment. Taken at face value, the palynomorph data suggest that the sediments of the Albuen Member were deposited in a more distal position relative to the source than that suggested by the previous assemblage zones. Amongst all palynomorphs, bisaccate pollen are known to be found farthest away from the source, because of their ability to be transported by air. However, bisaccate pollen are also known to have a thick wall and therefore may be preferentially preserved. Thus, although lack of marine palynomorphs could be interpreted in terms of a non-marine environment, it could also have resulted from selective destruction of the more thin-walled marine palynomorphs during intrusion of Palaeogene igneous sills and dykes in the Albuen Member.

Remarks. This interval was not recognised in previous studies by Lund \& Pedersen (1985) and Underhill \& Partington (1994).

\section{Assemblage Zone 5: Spheripollenites subgranulatus - Cerebropollenites macroverrucosus - Luehndea spinosa}

new assemblage zone

$\begin{array}{lll}\text { Occurrence. } & \text { Albuen } & 359-375.5 \mathrm{~m} \\ \text { Astartekløft } & 341-383 \mathrm{~m} \\ \text { Moskusoksekløft } & 359 \mathrm{~m} \text { (single sample) } \\ \text { Primulaelv } & 451 \mathrm{~m} \text { (single sample) }\end{array}$

In the Albuen reference section, Assemblage Zone 5 was only recorded from the lower Nathorst Fjeld Member of the Ostreaelv Formation; it should be noted that the underlying Astartekløft Member (also Ostreaelv Formation) was not sampled in this section so the potential downwards range of the assemblage is poorly constrained (Figs 3B, 3C, 4). At Astartekløft itself, however, Assemblage Zone 5 extends from the lowermost Astartekløft Member up into the Nathorst Fjeld Member (Figs 9, 10). Relative to the sequence stratigraphic scheme of Dam \& Surlyk (1995, 1998), Assemblage Zone 5 occurs within sequence SQ5, beginning immediately above the sequence boundary (SB5) in the Astartekløft section (Fig. 9) and extending up to some $10 \mathrm{~m}$ beneath the flooding surface at Albuen (Fig. 3C).

Reference section. Albuen, 359 m (sample 405466) $375.5 \mathrm{~m}$ (sample 405458; Figs 3B, 3C, 4). 


\section{Astartekløft}

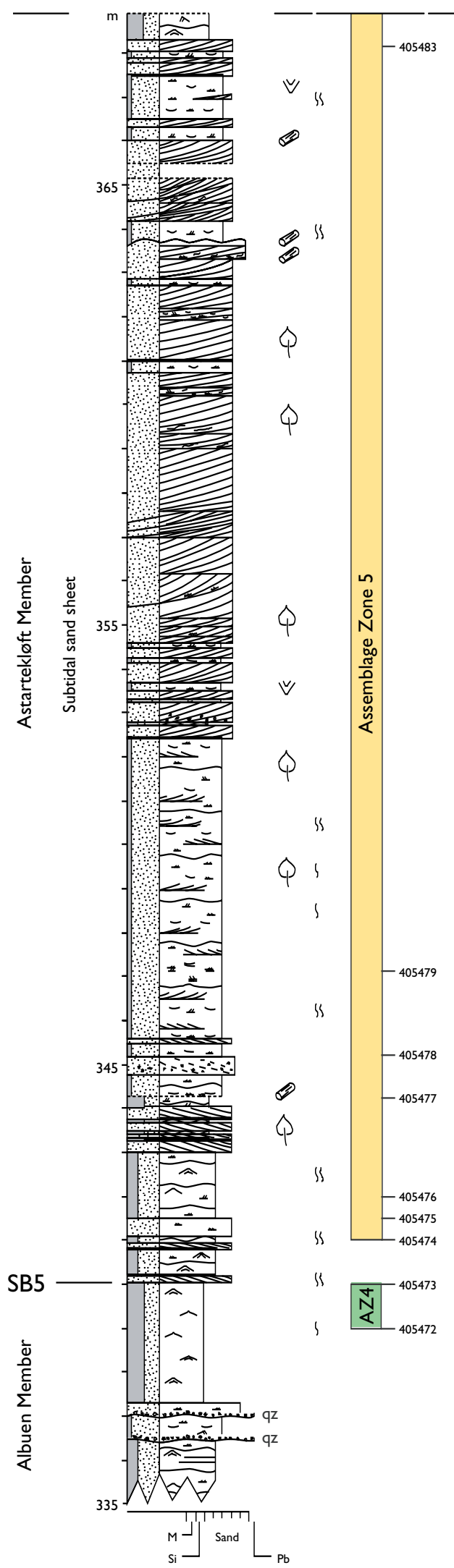

Fig. 9. Sedimentological log through the uppermost Albuen Member (Gule Horn Formation) and the Astartekløft and Nathorst Fjeld Members (Ostreaelv Formation) at Astartekløft (for location, see Fig. 1). Sequence boundary (SB5), palynomorph assemblage zones $(\mathbf{A Z})$ and sample numbers are indicated. For legend, see Fig. 3.

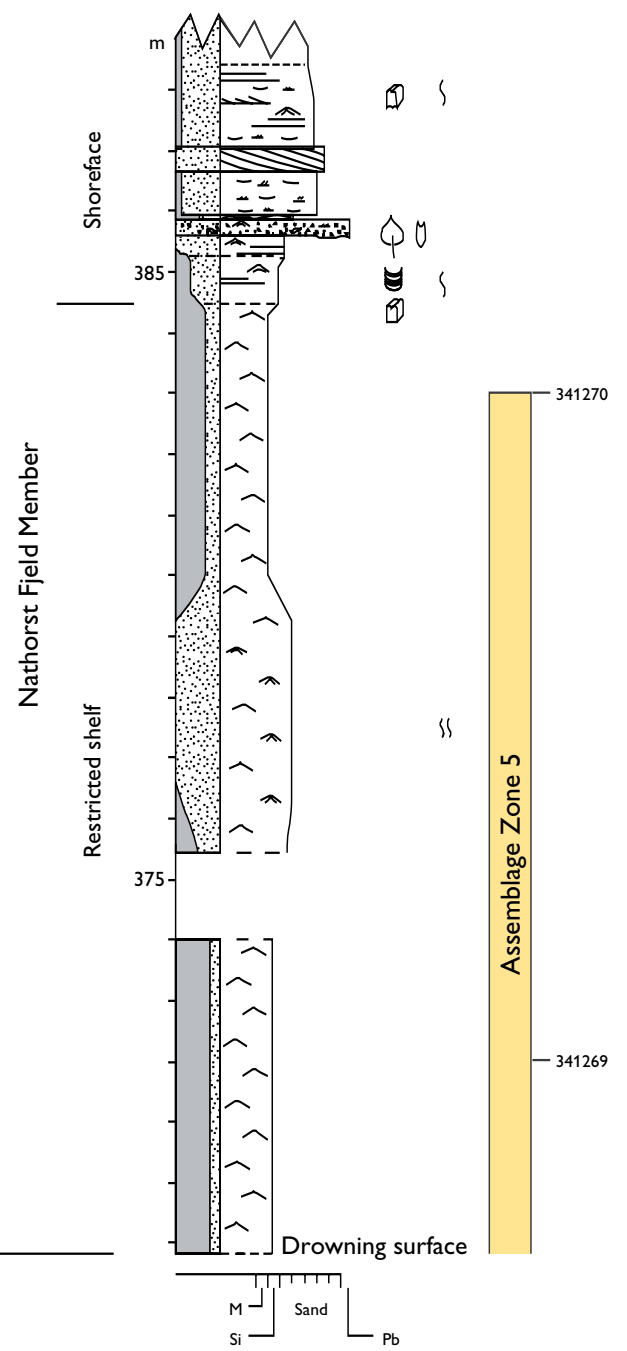




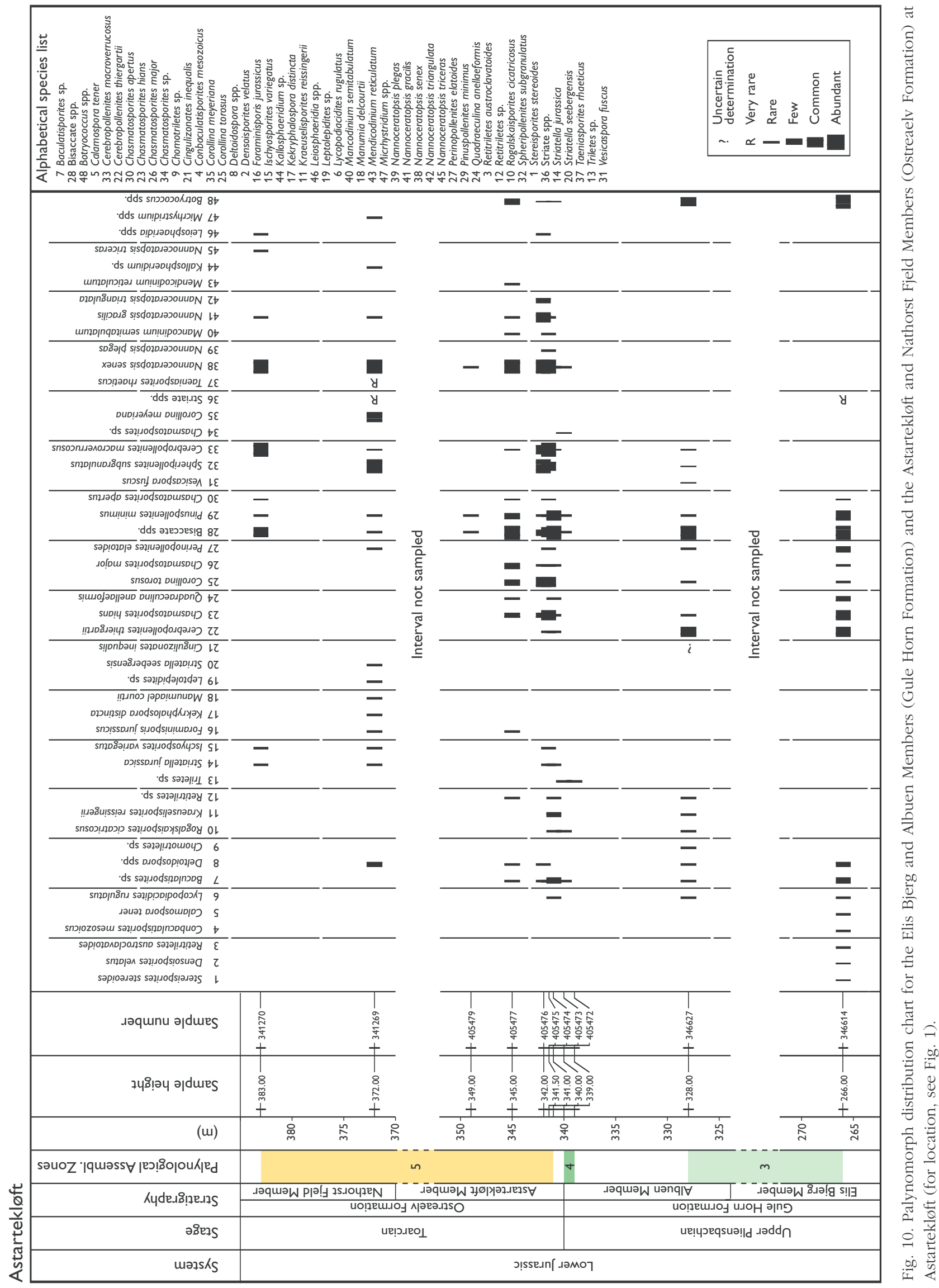


Additional section. Astartekløft, $341 \mathrm{~m}$ (sample 405474)

- 383 m (sample 341270; Figs 9, 10).

Base. The base of the assemblage is defined by the first appearance, in abundance, of Spheripollenites subgranulatus; at Albuen, this coincides with the first appearance of Luebndea spinosa, although this species was not recorded in the Astartekløft section.

Top. This is defined by the uppermost sample showing the palynomorph assemblage characteristic of the zone (i.e. sample 405458 at Albuen). The succeeding sample shows an acme of Perinopollenites elatoides, defining the base of Assemblage Zone 6. The top of the assemblage is not seen in the Astartekløft section (Fig. 9).

Characteristics. In Assemblage Zone 5, the pollen Spheripollenites subgranulatus appears in abundance for the first time; this species was only recorded in one sample below this level, in sample 346627 at $328 \mathrm{~m}$ in the Astartekløft section (Figs 9, 10). The assemblage is also marked by the reappearance of abundant Nannoceratopsis senex and $N$. gracilis. The pollen Cerebropollenites macroverrucosus and to a lesser degree Corollina torosus are more common than in the underlying assemblage. Spherical bodies of uncertain affinity are also abundant (on the distribution chart they are registered under micromiscellanea).

Suggested age. An Early-Late Toarcian age is proposed based on the presence and acme of Spheripollenites subgranulatus which is known to be abundant in Toarcian strata in the Danish Basin and the North Sea (Dybkjær 1991; Batten et al. 1994; Koppelhus \& Nielsen 1994; Koppelhus \& Batten 1996).

Palaeoenvironment. This assemblage contains elements indicative of both brackish and marine conditions.

Remarks. In Germany, the North Sea area and the Danish Basin, the dinoflagellate cyst Luehndea spinosa is known to appear within the Margaritatus, Spinatus and Tenuicostatum Zones which span the Late Pliensbachian to Early Toarcian (Morgenroth 1970; Riding \& Thomas 1992; Poulsen 1996). The abundant spherical bodies of unknown affinity are also known from svalbard, the North Sea and the Baltic Sea in upper Pliensbachian and Toarcian strata (Bjærke 1980b; Dybkjær 1991; Koppelhus \& Nielsen 1994); on the mid-Norway shelf, these forms are known to occur in Lower Toarcian strata (I. Throndsen, personal communication 1996).
This zone correlates with Assemblage Zone B of Lund \& Pedersen (1985). It has not been possible to recognise this assemblage in the data presented by Underhill \& Partington (1994). Comparison with the Microcysta erugata taxa range-zone of Smelror \& Below (1992) has been attempted, but the two zones have very few species in common.

\section{Assemblage Zone 6: Perinopollenites elatoides}

new assemblage zone

Occurrence.

$$
\begin{array}{ll}
\text { Albuen } & 377.5-434 \mathrm{~m} \\
\text { Enhjørningen Dal } & 414-424.67 \mathrm{~m} \\
\text { Sortehat (core) } & 12.65-26.28 \mathrm{~m}
\end{array}
$$

In the Albuen section, Assemblage Zone 6 extends from the upper Nathorst Fjeld Member through the Skævdal Member and much of the Trefjord Bjerg Member (all Ostreaelv Formation; Figs 3C, 4). Relative to the sequence stratigraphic scheme of Dam \& Surlyk $(1995,1998)$, the assemblage occurs within sequences SQ5 and SQ6, spanning the sequence boundary SB6 (Figs 3C, 4). Data for the Enhjørningen Dal and Sortehat sections is presented in the companion paper by Koppelhus \& Hansen (2003, this volume). In the Sortehat core, Assemblage Zone 6 is confined to the upper Ostreaelv Formation (Trefjord Bjerg Member); the top of the assemblage lies immediately beneath the boundary between the Ostreaelv and Sortehat Formations. At Enhjørningen Dal, however, Assemblage Zone 6 spans the boundary between these two formations, extending some $6 \mathrm{~m}$ up into the Sortehat Formation (Koppelhus \& Hansen 2003, this volume).

Reference section. Albuen, 377.5 m (sample 341243) 434 m (sample 405449; Figs 3C, 4).

Base. The base of the zone is placed at the sample in which Perinopollenites elatoides reaches its acme; it is accompanied by abundant Chasmatosporites hians and C. major.

Top. The upper boundary of Assemblage Zone 6 is placed at the last sample showing the palynomorph assemblage described here; above this level, Botryococcus sp. becomes very dominant, defining the base of Assemblage Zone 7. 
Characteristics. The zone is characterised particularly by the acme of Perinopollenites elatoides. The spores Staplinisporites caminus and Sestrosporites pseudoalveolatus have their first appearance within the zone together with the dinoflagellate cysts Phallocysta eumekes, Wallodinium laganum, Scriniocassis sp. and Dissiliodinium sp. The dinoflagellate cysts Nannoceratopsis gracilis and $N$. senex continue to be common in most of the samples. Botryococcus sp. re-appears at $392 \mathrm{~m}$ (sample 405456; Fig. 3C) and continues to be common to the top of this zone.

Suggested age. A Late Toarcian - early Aalenian age is suggested based on the first appearances of the spores Staplinisporites caminus and Sestrosporites pseudoalveolatus together with the dinoflagellate cysts Phallocysta eumekes, Wallodinium laganum, Scriniocassis sp. and Dissiliodinium sp. The occurrence of abundant Perinopollenites elatoides is a feature of Aalenian sediments in the Danish Basin and on Bornholm (Dybkjær 1991; Koppelhus \& Nielsen 1994).

Palaeoenvironment. The palynomorphs indicate that the palaeoenvironment was influenced by both fresh, brackish and marine waters, suggesting a nearshore environment.

Remarks. The two species Chasmatosporites hians and C. major are very abundant in the lowermost sample in this interval, higher up they become rare. In offshore mid-Norway, C. hians has a maximum appearance after the Spheripollenites acme (I. Throndsen, personal communication 1996). The pollen Callialasporites dampieri is known to appear in the uppermost Toarcian and lowermost Aalenian in north-west Scotland (Riding et al. 1991). This zone correlates with Assemblage Zone C in Lund \& Pedersen (1985) and the assemblage found in sample B2/57 at approximately $460 \mathrm{~m}$ in Primulaelv by Underhill \& Partington (1994). The dinoflagellate cyst Wallodinium laganum appears for the first time in this zone and is only known from the Late Toarcian Levesquei Zone in northern Germany and England (Feist-Burkhardt \& Monteil 1994). The ammonite Dactylioceras sp. occurs at the base of the Skxevdal Member at Nathorst Fjeld, suggesting an Early Toarcian Tenuicostatum Zone age for the lower part of the assemblage zone.

\section{Assemblage Zone 7: Botryococcus}

This assemblage is formally defined in the companion paper by Koppelhus \& Hansen (2003, this volume); a summary is given here.

$\begin{array}{lll}\text { Occurrence. Albuen } & 438.5-443.5 \mathrm{~m} \\ \text { Enhjørningen Dal } & 424.86-445 \mathrm{~m} \\ \text { Pelion } & 550-567 \mathrm{~m} \\ \text { Sortehat (core) } & 27.82-36.36 \mathrm{~m}\end{array}$

At Albuen, this assemblage is represented in the uppermost few metres of the Trefjord Member (Ostreaelv Formation) and extends up into the Sortehat Formation (Figs 3C, 4); additional data for the uppermost Trefjord Member and the overlying Sortehat Formation in the Albuen section are given in Koppelhus \& Hansen (2003, this volume). In the cored section from Sortehat, the assemblage occurs in the lower levels of the Sortehat Formation, the base of the zone being immediately above the base of the formation (Koppelhus \& Hansen 2003, this volume). At Enhjørningen Dal, Assemblage Zone 7 is also restricted to the lower Sortehat Formation although here the base is some $6 \mathrm{~m}$ above the lower boundary of the Sortehat Formation. Detailed discussion and the full dataset are given in Koppelhus \& Hansen (2003, this volume). Assemblage Zone 7 occurs within the lower levels of sequence SQ7 of Dam \& Surlyk (1995, 1998).

Reference section. Sortehat (core), $27.82 \mathrm{~m}$ (sample 303143-73) - 36.36 m (sample 303143-62).

Additional sections. See Koppelhus \& Hansen (2003, this volume).

Base. The base of the assemblage is placed at the first sample in which Botryococcus sp. overwhelmingly dominates the assemblage. In the Albuen section (Figs 3C, 4 ), this event coincides with the first co-occurrence of Callialasporites dampieri (pollen) and Mendicodinium groenlandicum (dinoflagellate cyst) although in other sections (e.g. Enhjørningen Dal, Sortehat; Koppelhus \& Hansen 2003, this volume) these species first occur together some metres below the Botryococcus sp. influx.

Top. The upper boundary is defined by the uppermost sample showing the Botryococcus-dominated assemblage. Above this level, Botryococcus sp. disappear and Nannoceratopsis gracilis and $N$. senex become abundant once more. 
Characteristics. The assemblage is characterised by the overwhelming dominance of Botryococcus sp. and the scarcity of dinoflagellates.

Suggested age. An Aalenian age is proposed based on the abundance of Callialasporites dampieri. Pollen from the genus Callialasporites are known to appear first in sediments of Late Toarcian and Aalenian age in Sweden and the Danish area (Guy-Ohlson 1988; Koppelhus \& Nielsen 1994).

Palaeoenvironment. The fresh and brackish water alga Botryococcus is known from recent environments to produce blooms at certain times of the year. The colonies float at the water surface under calm conditions and subsequently sink when the water is disturbed. When they die, they float within the surface waters and can be transported by wind far from the area where they were produced. Palaeoenvironmental interpretation based solely on the presence of Botryococcus is therefore dangerous; the degree to which the Botryococcus in this succession is allochthonous is unknown. Further discussion of the environmental implications of this assemblage is given by Koppelhus \& Hansen (2003, this volume).

\section{Additional palynological results}

As noted earlier, definition of the six assemblage zones described here is based primarily on the section at Albuen, the palynostratigraphy of which is thus presented in detail above. In addition to this reference section, however, a series of other sections were included in the study, some of which yield important supplementary data for the definition of the assemblage zones (see above). The palynostratigraphic results from these additional localities, spread widely in the Jameson Land Basin (Fig. 1), are described below, broadly from south to north.

\section{Rævekløft}

At Rævekløft, nine samples were collected, six from the Rævekløft Formation (405435-405440) and three from the Elis Bjerg Member (Gule Horn Formation, 405441-405443; Fig. 11). The samples collected from the Rævekløft Formation are separated by a gap of c. $100 \mathrm{~m}$ from those collected in the Elis Bjerg Member and the boundary between the two units was not exposed. All the samples yielded abundant poorly preserved palynomorphs. Terrestrial material dominates together with the freshwater alga Botryococcus sp. Bisaccate pollen are the most abundant palynomorphs in all the samples. A few acritarchs and questionable dinoflagellate cysts were found. Based on the presence of the spores Deltoidospora and Baculatisporites, the pollen Cerebropollenites thiergartii and Pinuspollenites minimus and the lack of dinoflagellate cysts, the samples 405435-405440 (?upper Rævekløft Formation) are assigned to Assemblage Zone 1. In the samples 405441-405443 (Elis Bjerg Member), the dinoflagellate cysts Nannoceratopsis senex and Mancodinium semitabulatum appear for the first time, indicating that the assemblage belongs to Assemblage Zone 2.

Suggested age. An Early Pliensbachian age is suggested for Assemblage Zone 1, based on the presence of Cerebropollenites thiergartii together with Pinuspollenites minimus; a Late Pliensbachian age is proposed for Assemblage Zone 2 based on the occurrences of Nannoceratopsis senex and Mancodinium semitabulatum.

\section{Tancrediakløft}

Only one sample (341229; Rævekløft Formation) was studied from this locality. The sample contained only black material which was not identifiable.

\section{Qupaulakajik}

Only one sample (341254; Albuen Member, Gule Horn Formation) was studied from this locality. The palynomorphs were black and indeterminate.

\section{Goniomyakløft}

Five samples were studied (Figs 7, 8). The sample 405467, from the uppermost part of Rævekløft Formation, yielded an assemblage rich in poorly preserved palynomorphs, dominated by terrestrial material. However, several specimens of the dinoflagellate cyst genus Dapcodinium were found together with a single specimen of Tasmanites. The former are similar to Dapcodinium priscum, but not identical to specimens of this species described from Northwest Europe. The assemblage is suggested to belong to Assemblage Zone 1. 


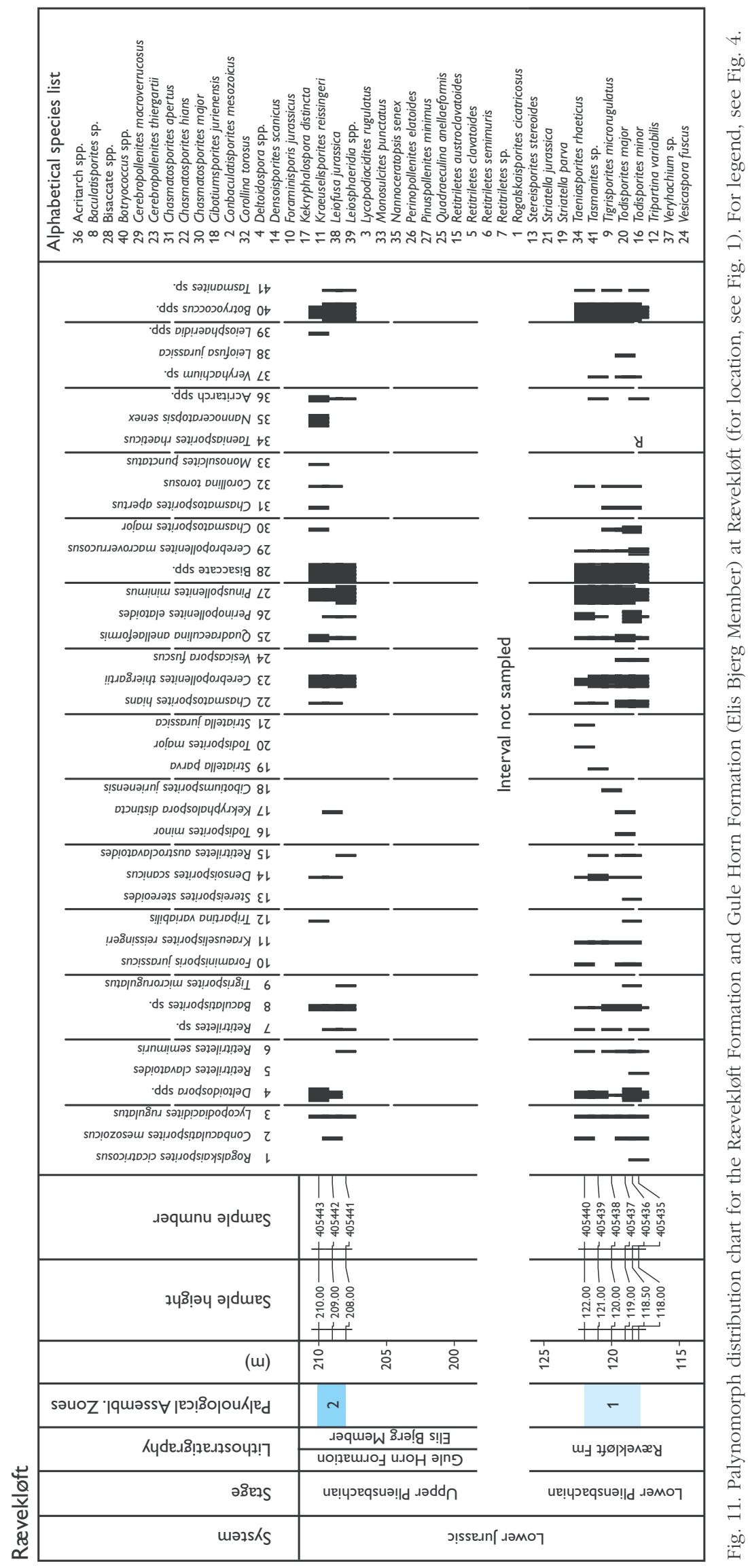


Sample 405468 was collected just beneath the boundary between the Rævekløft Formation and the succeeding Elis Bjerg Member (Gule Horn Formation). This sample yielded a similar palynomorph assemblage to that described above but included the first appearance of the dinoflagellate cyst Mancodinium semitabulatum. It is suggestive of the somewhat younger Assemblage Zone 2. The samples 405469-405471 are from the Elis Bjerg Member. They lack recognisable dinoflagellate cysts although acritarchs and some questionable dinoflagellate cysts were found together with Crassosphaera sp., foraminiferal inner linings and abundant Botryococcus sp. This assemblage is also suggested to belong to Assemblage Zone 2.

Suggested age. An ?Early-Late Pliensbachian age is proposed, based on the appearance of Mancodinium semitabulatum.

\section{Astartekløft}

Fourteen samples from the northern and southern side of Astartekløft were investigated palynologically (Figs 9, 10; note that the barren samples are not shown on Fig. 10). The lowermost samples, 346614 at $266 \mathrm{~m}$ and 346627 at 328 m, are from the lower Elis Bjerg Member (Gule Horn Formation) and the lower Albuen Member (Gule Horn Formation), respectively (Fig. 10). These samples are dominated by Botryococcus sp. and bisaccate pollen, together with common Cerebropollenites thiergartii and Chasmatosporites hians, and are referred to Assemblage Zone 3.

The two samples 405472 and 405473 from the upper Albuen Member (Figs 9, 10) contain abundant bisaccate pollen; this and the lack of other palynomorphs indicate Assemblage Zone 4.

Samples 405474 and 405475 are from the lowermost beds of the Astartekløft Member; they record the first appearance of Spheripollenites subgranulatus, together with abundant Cerebropollenites macroverrucosus and the re-appearance of the dinoflagellate cyst Nannoceratopsis senex. Sample 405477, also from the Astartekløft Member, lacks Spheripollenites subgranulatus but Nannoceratopsis senex is common. In sample 405483 from the Astartekløft Member, the organic material is black and indeterminate and thus this sample does not appear on Figure 10. In sample 341269, from the Nathorst Fjeld Member, Spheripollenites subgranulatus is abundant, and in the uppermost sample (341270), also from the Nathorst Fjeld Member, Spheripollenites subgranu- latus is absent but Nannoceratopsis senex is abundant together with Cerebropollenites macroverrucosus. It is suggested that the assemblages recorded between sample 405474, at the base of the Astartekløft Member, and the uppermost sample 341270, in the Nathorst Fjeld Member, are compatible with Assemblage Zone 5 as defined from the Albuen section.

Suggested age. The lowermost part of the succession is referred to the Upper Pliensbachian based on the abundance of Cerebropollenites thiergartii and Chasmatosporites hians. An Early Toarcian age for the uppermost part is based on the first appearance and abundance of both Spheripollenites subgranulatus and Cerebropollenites macroverrucosus.

\section{Moskusoksekløft}

Only one sample (341260; Nathorst Fjeld Member, Ostreaelv Formation) was investigated from this locality; it yielded the dinoflagellate cysts Nannoceratopsis senex and $N$. triangulata and the pollen Spheripollenites subgranulatus and Cerebropollenites macroverrucosus (Fig. 12A). This assemblage is referred to Assemblage Zone 5 .

Suggested age. An Early Toarcian age is proposed based on the presence of Spheripollenites subgranulatus and Cerebropollenites macroverrucosus together with Nannoceratopsis senex and $N$. triangulata.

\section{Harris Fjeld}

One sample (346741) was studied from this locality, from the lower part of Elis Bjerg Member (Fig. 12B). The palynological assemblage is dominated by poorly preserved bisaccate pollen and the assemblage was deemed too poor to determine to which assemblage zone it belongs.

\section{Primulaelv}

Three samples (346746, 346745, 346753) were analysed from this locality (Fig. 12C), the first two from the Elis Bjerg Member and the third from the lowermost mudstones of the Skævdal Member. The lowermost sample is tentatively referred to Assemblage Zone 1, based on a very poor assemblage of bisaccates, Pinuspollenites 


\section{A: Moskusoksekløft}

\begin{tabular}{|c|c|c|c|c|c|c|c|c|c|c|c|c|c|c|c|c|}
\hline 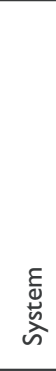 & 蛋 & 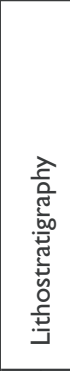 & 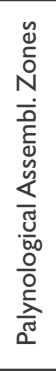 & 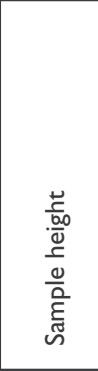 & 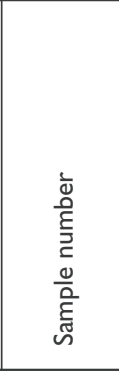 & 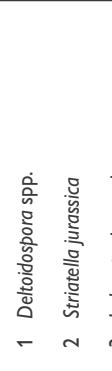 & 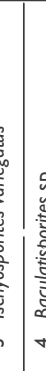 & 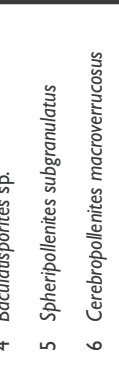 & 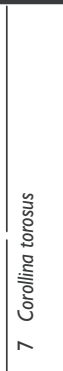 & 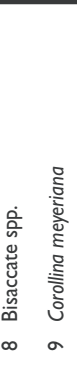 & 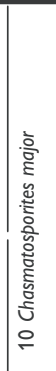 & 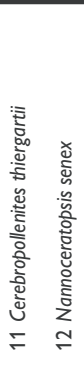 & 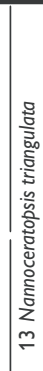 & 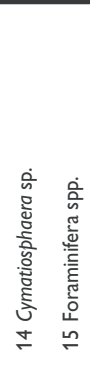 & 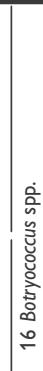 & 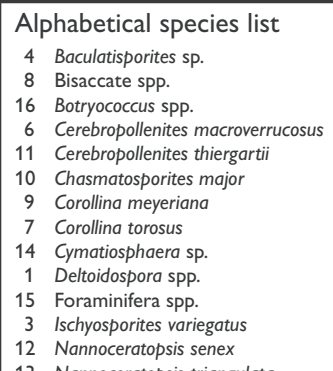 \\
\hline 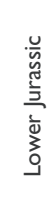 & 胥 & 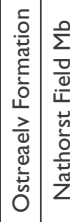 & 5 & +359.00 & $+341260-$ & I I & & I & I & I & & I & I & I I & I & $\begin{array}{ll}5 & \text { Spheriplennites subrranulatus } \\
2 & \text { Striatella jurassica }\end{array}$ \\
\hline
\end{tabular}

\section{B: Harris Fjeld}

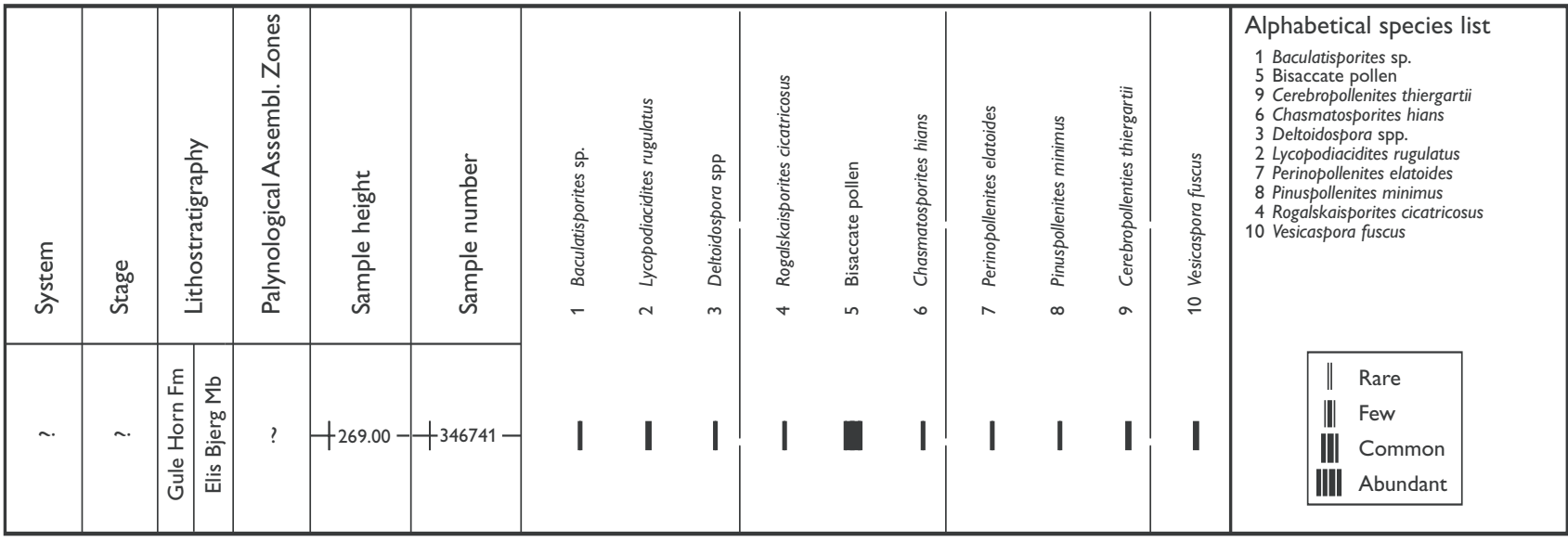

\section{C: Primulaelv}

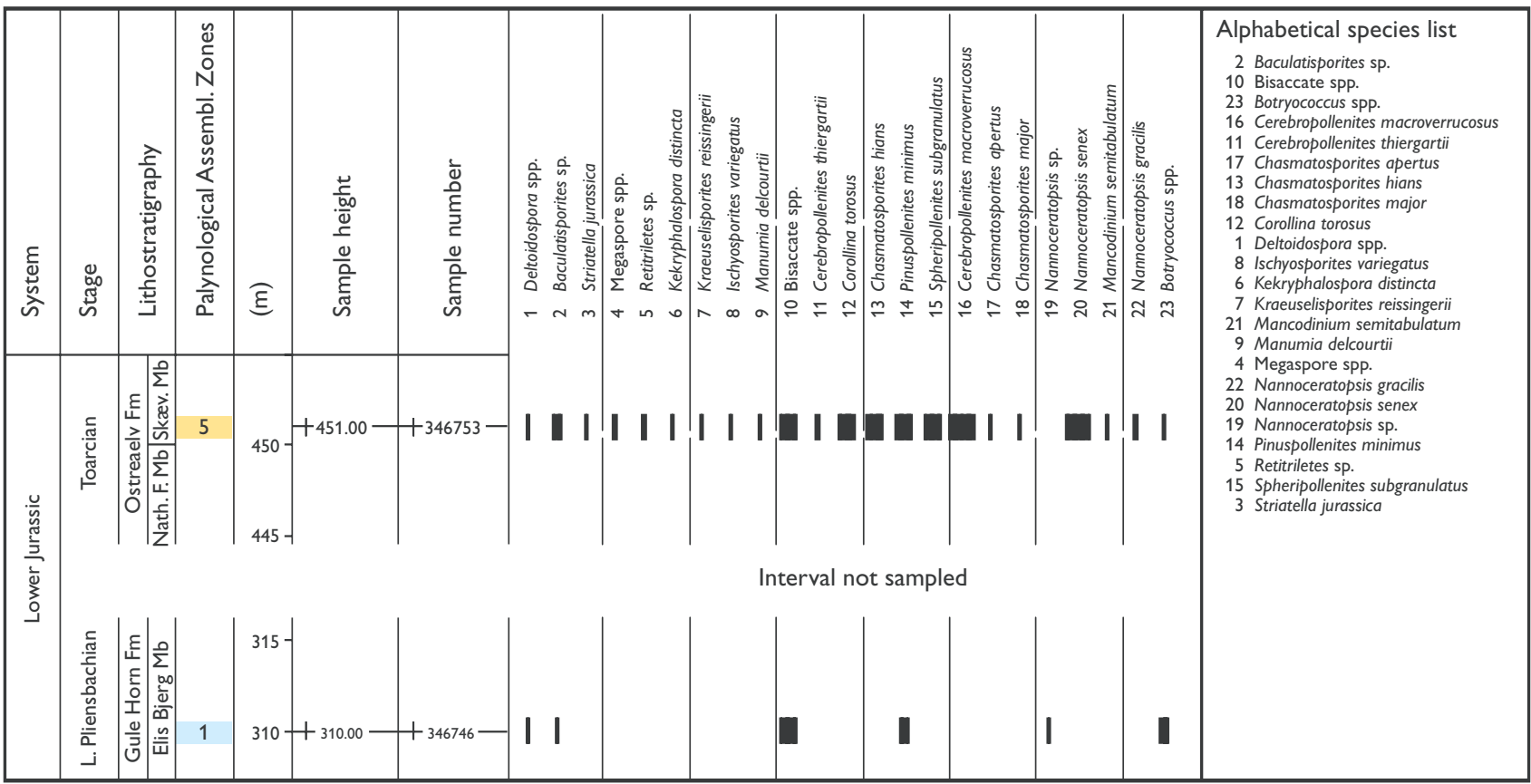

Fig. 12. Palynomorph distribution charts (for locations, see Fig. 1). A, Ostreaelv Formation (Nathorst Fjeld Member) at Moskusoksekløft. B, Gule Horn Formation (Elis Bjerg Member) at Harris Fjeld. C, Gule Horn Formation (Elis Bjerg Member) and Ostreaelv Formation (Nathorst Fjeld (Nath. F.) and Skævdal (Skæev.) Members) at Primulaelv. 


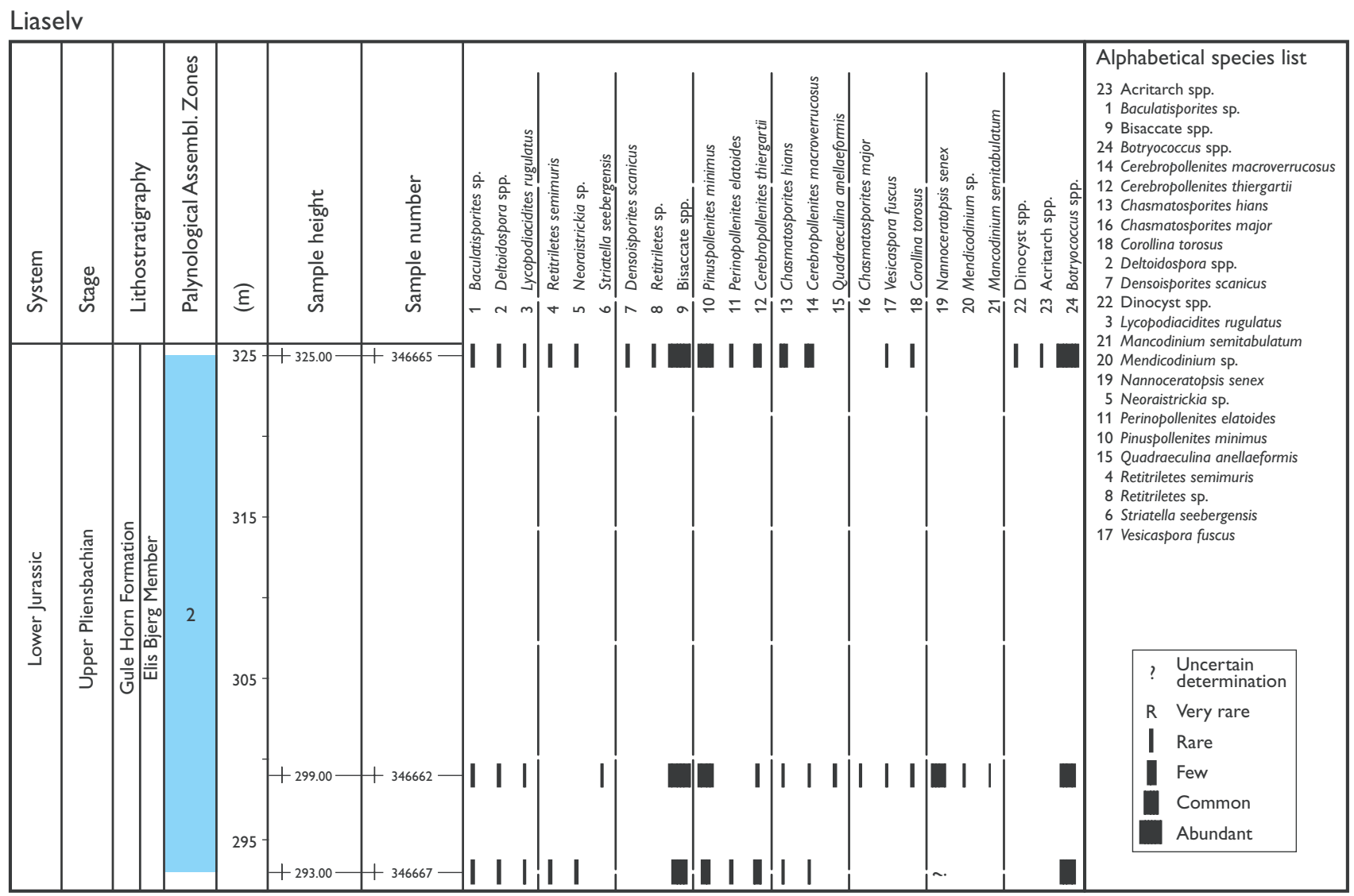

Fig. 14. Palynomorph distribution chart for the Gule Horn Formation (Elis Bjerg Member) at Liaselv (for location, see Fig. 1).

minimus and common Botryococcus sp. The second sample (346745) was barren and thus does not appear on the distribution chart (Fig. 12C). The uppermost sample is referred to Assemblage Zone 5 on the basis of abundant Spheripollenites subgranulatus, Cerebropollenites macroverrucosus and Nannoceratopsis senex.

Suggested age. A Late Pliensbachian age is tentatively suggested for the lowermost sample (346746) based on a very poor assemblage in which only bisaccates and Pinuspollenites minimus are common. An Early Toarcian age is suggested for the uppermost sample (346753) based on abundant Spheripollenites subgranulatus, Cerebropollenites macroverrucosus and Nannoceratopsis senex.

\section{Lepidopteriselv}

Ten samples (139137-139146) were studied from this section and all of them are rich in palynomorphs (Fig. 13, following page 744). These samples were collected by Claus Heinberg and Tove Birkelund in 1974, and they were thus not assigned to the recently-defined members. However, comparing their field notes with our sedimentological logs, it has been possible to assign the samples to the Elis Bjerg Member.

The samples 139237-139240 are rich in the spores Deltoidospora and Baculatisporites, the pollen Pinuspollenites minimus and Cerebropollenites thiergartii, bisaccate pollen and Botryococcus sp. In sample 139141, the dinoflagellate cyst Nannoceratopsis senex is very abundant and Botryococcus sp. is rare. Samples 139142-139146 are again rich in spores and pollen and Botryococcus sp. whereas dinoflagellate cysts are rare.

The palynological results allow us to suggest that the lowermost five samples (139137-139141) belong to Assemblage Zone 2. This is based on the common occurrence of Cerebropollenites thiergartii and Nannoceratopsis senex. The next five samples (139142-139146) are referred to Assemblage Zone 3 based on the presence of Cerebropollenites thiergartii, Pinuspollenites minimus and bisaccate pollen and the fact that dinoflagellate cysts are rare. 
Suggested age. A Late Pliensbachian age is proposed for the samples 139137-139146 based on the presence of Cerebropollenites thiergartii, Pinuspollenites minimus, Nannoceratopsis species and Mancodinium semitabulatum.

\section{Liaselv}

Three samples (346662, 346665, 346667) were analysed from the Elis Bjerg Member (Fig. 14); in general, preservation of the palynomorphs is very poor. All three samples are dominated by bisaccate pollen and Botryococcus sp. and it is suggested that they belong to Assemblage Zone 2.

Suggested age. A Late Pliensbachian age has been suggested because of the abundance of Pinuspollenites minimus and bisaccates.

\section{Horsedal and the Deltoidospora Assemblage}

Four samples (346696, 346700, 346701, 346703) were analysed from the Horsedal Member at Horsedal (Figs 15, 16). Sample 346696 was barren. Sample 346700 , from a coal bed, yielded an assemblage composed predominantly of laevigate spores (pteridophyte spores) of the genus Deltoidospora. Such an assemblage has not been recorded before in samples from the Neill Klinter Group at Albuen or at any other locality in Jameson Land and Scoresby Land. The assemblage totally lacks microplankton. Sample 346701 yielded a more diverse assemblage, but is dominated by bisaccate pollen and Botryococcus sp. The uppermost sample, 346703, yielded only bisaccate pollen.

It has not, based on the present material, been possible to place this assemblage within any of the assemblage zones defined above from the Albuen succession. The assemblage is thus defined as a new assemblage, named the Deltoidospora Assemblage, which is presently only recognised at Horsedal in the Horsedal Member of the Ostreaelv Formation.

Suggested age. This assemblage is not age specific; it could occur within any stage of the Jurassic.

Palaeoenvironment. This assemblage is indicative of an enclosed swamp area (lagoon, pond, small lake) with a dense vegetation of ferns.

\section{Horsedal}

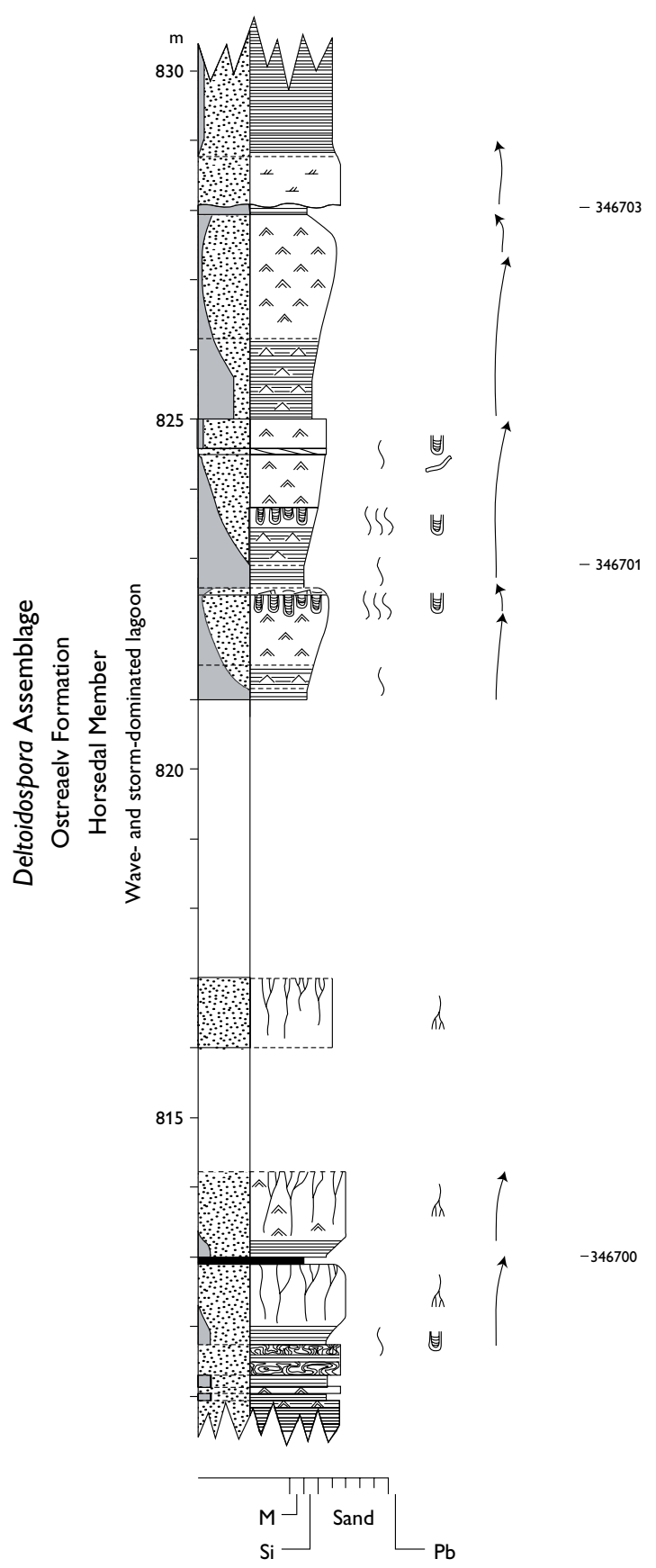

Fig. 15. Sedimentological log through part of the Horsedal Member (Ostreaelv Formation) in Horsedal (for location, see Fig. 1). Sample numbers are indicated; arrows denote grain-size trends. For legend, see Fig. 3.

\section{Ranunkeldal}

Seven samples were analysed from this section (Figs 5 , 6). Samples 341167-341170 were sampled in the uppermost part of the Kap Stewart Group and samples 


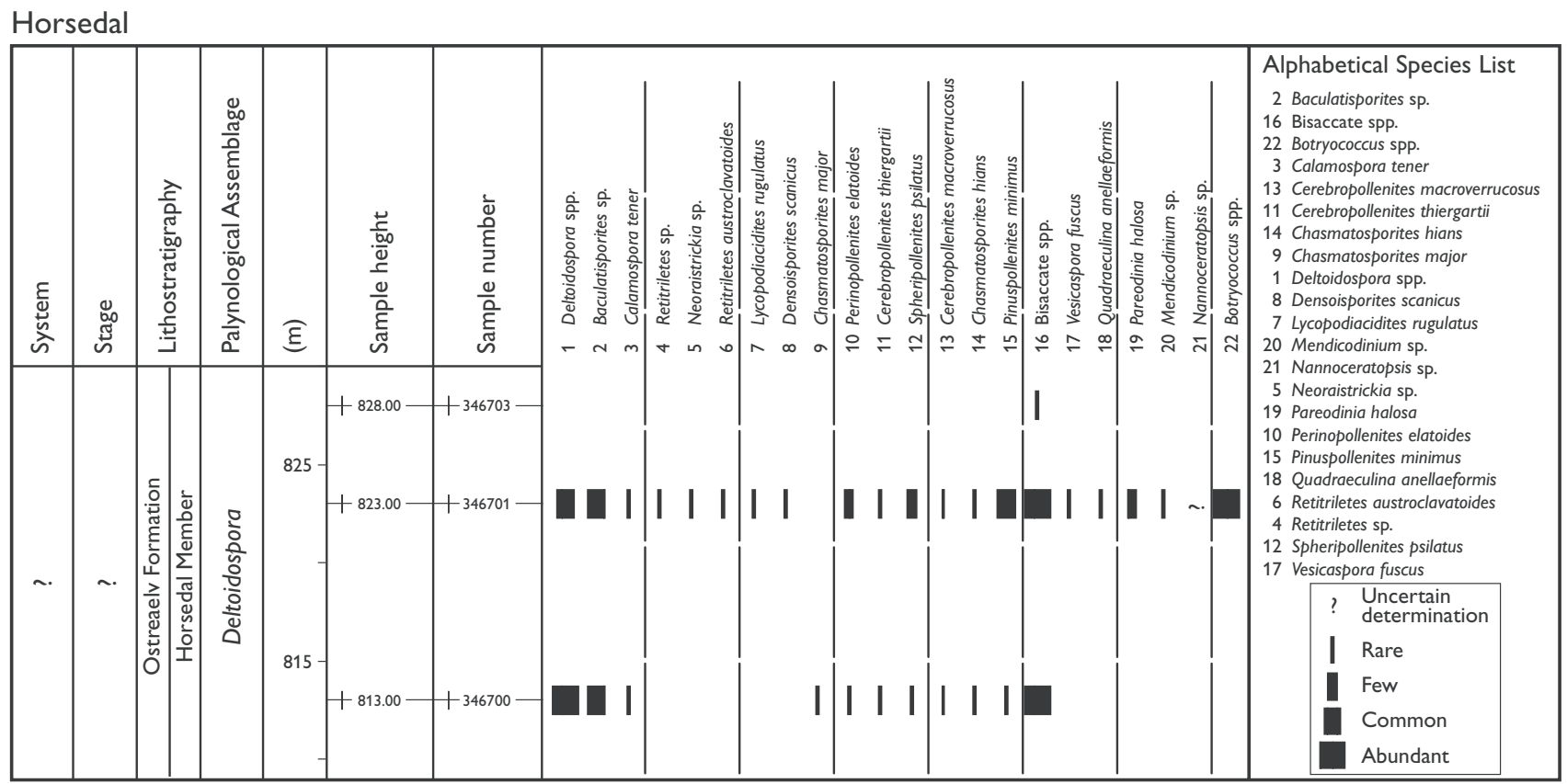

Fig. 16. Palynomorph distribution chart for the Horsedal Member (Ostreaelv Formation) in Horsedal (for location, see Fig. 1).

341171-341173 are from the Elis Bjerg Member of the Gule Horn Formation. Preservation of the palynomorphs from all these samples is very poor. However, the palynomorph assemblages are dominated by the laevigate spore Deltoidospora sp., bisaccate pollen, Chasmatosporites hians, Cerebropollenites thiergartii and Quadraeculina anellaeformis. Botryococcus sp. is present in all samples, but is only abundant in the uppermost sample. In sample 341168, a dinoflagellate cyst has been found; it is similar to Mendicodinium reticulatum, but shows some anomalous features. The occurrence of this dinoflagellate cyst suggests that the environment was influenced by brackish waters, at least for a short time. A single Nannoceratopsis gracilis cyst was observed in sample 341171 from $306 \mathrm{~m}$. In this sample, a Tasmanites was found together with a poorly preserved foraminiferal inner-lining. In the uppermost sample, several Leiofusa jurassica were recorded.

The palynomorph assemblages from the Kap Stewart Group in Ranunkeldal are suggested to belong to a separate assemblage zone. The samples from the Elis Bjerg Member are referred to Assemblage Zone 1.

Suggested age. A ?Late Sinemurian age is suggested for the Kap Stewart Group samples because of the occurrence of the dinoflagellate comparable to Mendicodinium reticulatum. This species has been found on Bornholm, Denmark in sediments of latest Sinemurian and earliest Pliensbachian age (Batten et al. 1994; Koppelhus \& Nielsen 1994). A Pliensbachian age is sug- gested for the Elis Bjerg Member samples because of the presence of Nannoceratopsis gracilis.

Palaeoenvironment. A non-marine, freshwater environment is indicated for the Kap Stewart Group samples, although the presence of a dinoflagellate cyst in sample 341168 suggests the influence of brackish water, albeit only temporarily. The samples from the Elis Bjerg Member indicate marine influence.

\section{Depositional environments and assemblage zones}

The palynological results presented above provide an additional dataset with which to constrain palaeoenvironmental and sequence stratigraphic interpretations. In the following section, the individual palynological assemblage zones, together with the Deltoidospora Assemblage, are discussed in relation to the sedimentological and stratigraphic data.

\section{Assemblage Zone 1: Cerebropollenites thiergartii - Pinuspollenites minimus - Botryococcus}

This assemblage zone is characteristic of the sedimentary succession referred to sequence SQ2 of Dam \& Surlyk (1995, 1998) at Qupaulakajik, Albuen and 
Goniomyakløft, which consists of the upper part of the Rævekløft Formation and the lowermost part of the Elis Bjerg Member (Fig. 17). It is also present in the lower part of sequence SQ3 at Primulaelv, however, and in the lowermost part of the Elis Bjerg Member in Ranunkeldal, just above the Kap Stewart Formation. The base of the assemblage zone thus coincides with the base of sequence SQ1 (i.e. SB1) and the zone extends up into the lowermost part of sequence SQ3 of Dam \& Surlyk (1995, 1998). At the studied locations, the upper part of the Rævekløft Formation consists of cross-bedded, fossiliferous medium- to very coarse-grained sandstones (Fig. 7), interpreted to represent fields of dunes or shoreface ridges on the shoreface (Dam \& Surlyk 1995, 1998). In the Elis Bjerg Member, the assemblage is present in subtidal sand sheet, shoreface and offshore transition deposits (Figs 3A, 5). The Rævekløft Formation is capped by an important drowning surface that defines the base of the Elis Bjerg Member (Figs 7, 17; Dam \& Surlyk 1995, 1998).

The palynological assemblage is uniform, being dominated by bisaccate pollen and the freshwater to brackish alga Botryococcus sp. Spores include common Deltoidospora and Baculatisporites sp., and locally Lycopodiacidites rugulatus. Among the pollen, Pinuspollenites minimus and Cerebropollenites thiergartii are common. Acritarchs are rare and dinoflagellate cysts are absent with the exception of one Nannoceratopsis gracilis cyst and the undetermined dinoflagellate cyst (cf. Mendicodinium reticulatum) from the Ranunkeldal section. The assemblage probably reflects a vegetation with few fern species and several gymnosperm species. These grew close to a fresh or brackish water environment, where the Botryococcus algae lived. When seen in the light of the strong marine indicators provided by the macrofossils, sedimentary structures and ichnology, it is suggested that this palynomorph assemblage is dominantly allochthonous, having been transported from a terrestrial to a shallow marine environment. Similar palynomorph assemblages are known from other areas, for example in the uppermost Sinemurian and lowermost Pliensbachian of Bornholm in the Baltic Sea (Koppelhus \& Nielsen 1994).

\section{Assemblage Zone 2: Nannoceratopsis-Botryococcus}

The assemblage zone is characteristic of the middle part of the Elis Bjerg Member at Albuen, Lepidopteriselv and Liaselv in subtidal sand sheet and storm-dominated shoreface deposits, but also occurs in similar deposits in the lower part of the member at Goniomyakløft and the upper part of the member at Qupaulakajik (Figs 2, 17). The assemblage zone is most characteristic of the lower part of sequence SQ3 of Dam \& Surlyk (1995, 1998), but is also locally present in the uppermost part of sequence SQ2 (Fig. 17). The top is placed below the transition from subtidal sand sheet deposits to tidal channel deposits of the Elis Bjerg Member (Fig. 3A).

The palynomorph assemblage is dominated by the same spores, pollen and Botryococcus sp. that characterise Assemblage Zone 1, but the incoming of Nannoceratopsis senex, $N$. gracilis, Parvocysta barbata and Mancodinium semitabulatum together with Limbicysta bjaerkei and a few more acritarchs indicates an increase in marine influence. In most of the samples, there are between three and seven different dinoflagellate cyst species and between one and five acritarch species.

The marine interpretation of this palynomorph assemblage zone is in agreement with the sedimentological and ichnological data, which also indicate a shallow marine environment (Dam \& Surlyk 1995, 1998).

\section{Assemblage Zone 3: Chasmatosporites - Cerebropollenites thiergartii - Botryococcus}

The assemblage is characterised by rare dinoflagellate cysts such as Mendicodinium reticulatum and Nannoceratopsis spp. A few acritarchs are present, together with abundant pollen and Botryococcus. The assemblage is present in the upper part of the Elis Bjerg Member, but may extend into the lowermost part of the Albuen Member (Fig. 17). Assemblage Zone 3 is dominantly present in stacked tidal channel and wave- and storm-dominated shoreface deposits (Fig. 3A; Dam \& Surlyk 1995, 1998), whereas the sample from the Albuen Member was from heterolithic lower shoreface deposits. The base of the assemblage zone is placed just below the transition from subtidal sand sheet deposits to tidal channel deposits. At Albuen, the top of the zone occurs just beneath the boundary between tidal channel deposits of the Elis Bjerg Member and storm-dominated offshore transition deposits of the Albuen Member; this boundary has been interpreted as a coalesced sequence boundary and transgressive surface (Dam \& Surlyk 1995, 1998). At Astartekløft, however, the lowermost sample in the Albuen Member is also referred to Assemblage Zone 3 (Fig. 10). 


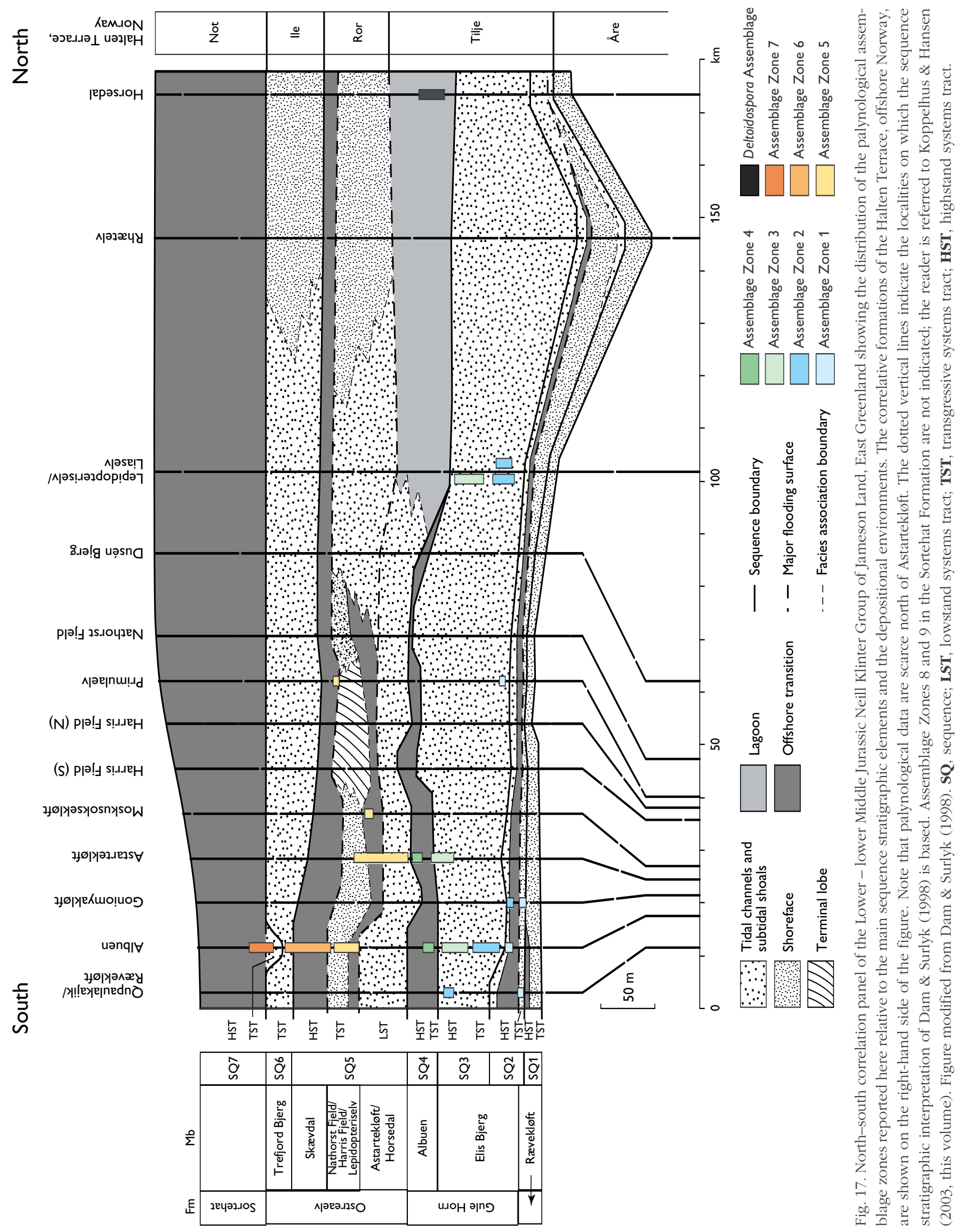


The shift from Assemblage Zone 2 to Assemblage Zone 3 records a change from a marine setting to an environment with a strongly terrestrial character, albeit with evidence of periodic marine influence. This flo$\mathrm{ral} /$ faunal change is compatible with the sedimentological record (Dam \& Surlyk 1995, 1998), which indicates a change from subtidal sand sheet deposition in a shallow marine environment to a tidal channel environment, where a larger degree of terrestrial influence is to be expected.

\section{Assemblage Zone 4: Bisaccates}

This palynomorph assemblage is very uniform, being dominated overwhelmingly by bisaccate pollen. The combined data from the Albuen and Astartekløft sections suggest that the assemblage characterises much of the Albuen Member of the Gule Horn Formation. At Albuen, the base of the assemblage zone occurs immediately above the coalesced sequence boundary and transgressive surface that separates the Elis Bjerg and Albuen Members (Fig. 3B; SB4 of Dam \& Surlyk 1995, 1998); at Astartekløft, in contrast, Assemblage Zone 3 straddles this sequence boundary, Assemblage Zone 4 being recognised only in the uppermost levels of the Albuen Member (Fig. 10).

The upper levels of the Albuen Member proved inaccessible at Albuen and were not sampled; the top of the zone is placed at the uppermost sample, some $12 \mathrm{~m}$ below the top of the member. At Astartekløft, however, detailed sampling across the boundary between the Albuen and Astartekløft Members demonstrated that the boundary between Assemblage Zones 4 and 5 coincides closely with this surface which is interpreted as a sequence boundary (Figs 9, 10, 17; SB5 of Dam \& Surlyk 1995, 1998).

The Albuen Member is heterolithic, being composed of alternating mudstones and well-sorted fine-grained sandstones deposited in a storm-dominated lower shoreface environment (Dam \& Surlyk 1995, 1998). A few coarse-grained pebbly sheets, moulded into large symmetrical ripples, and massive sandy mudstones deposited from debris flows are commonly interbedded with the heterolithic deposits.

It is well-known that bisaccate pollen is commonly concentrated in distal marine settings, beyond the reach of other terrestrial palynomorphs. On this basis, this assemblage could therefore be interpreted to reflect an offshore marine environment, beyond the depositional range of other land-derived elements. The sedimento- logical data, however, testify to a lower shoreface environment (Dam \& Surlyk 1998), and other land-derived elements should therefore be present. The absence of marine palynomorphs is also difficult to explain. As discussed earlier, such thin-walled forms may have been selectively destroyed by thermal effects caused by the intrusion of volcanics into the sediments. Alternatively, the lack of marine palynomorphs could reflect partial isolation of the embayment resulting in the development of a fresh to brackish water environment; this could also explain the lack of tidal indicators in this member.

\section{Assemblage Zone 5: Spheripollenites subgranulatus - Cerebropollenites macroverrucosus - Luehndea spinosa}

The base of Assemblage Zone 5 in the Albuen section is characterised by the sudden incoming of Spheripollenites subgranulatus and the reappearance of dinoflagellate cysts together with a more diverse pollen flora and the freshwater alga Botryococcus sp. In sample 405466 at $259 \mathrm{~m}$ in the Albuen section (Figs 3B, 4A), Luehndea spinosa appears for the first time together with common spherical dinocysts that are of unknown affinity, but have been recorded from Spitsbergen, the Danish Subbasin and Bornholm, Denmark (Bjærke 1980a; Dybkjær 1991; Koppelhus \& Nielsen 1994).

At Astartekløft, the lower zone boundary is placed just above the sequence boundary between the Albuen and Astartekløft Members (Figs 9, 17; SB5 of Dam \& Surlyk 1995); the upwards extent of the zone is poorly constrained at this locality. At Albuen, the upper boundary of the zone is placed approximately $10 \mathrm{~m}$ below the drowning surface that separates the heavily bioturbated shoreface sandstones of the Nathorst Fjeld Member from bioturbated shelf deposits of the Skæevdal Member (Fig. 3C). At Primulaelv, a single sample shows that this assemblage is also present just above the drowning surface (Fig. 17). Along Neill Klinter, the Astartekløft Member includes three facies associations, tidal channel, subtidal sand sheet and storm-dominated sandy shoal associations (Fig. 3B). The tidal channel and subtidal sand sheet deposits are similar to those of the Elis Bjerg Member, discussed above under Assemblage Zones 2 and 3. The storm-dominated sandy shoal deposits form a laterally continuous succession, composed of well-sorted fine- to medium-grained sandstone beds (Dam \& Surlyk 1995, 1998). The Nathorst Fjeld Member forms a single coarsening-upwards succession consisting of alternating silty mudstones and 
thin laminae of very fine- to fine-grained sandstones, grading upwards into fine- to coarse-grained sandstones. The sandstones are cross-bedded, wave ripple cross-laminated, hummocky cross-stratified and bioturbated. The coarsening-upwards succession reflects an increase in energy with time and is interpreted to record progressive shallowing from an offshore transition setting to a shoreface environment.

The Spheripollenites subgranulatus-Cerebropollenites macroverrucosus - Luebndea spinosa assemblage comprises a mixture of spores, pollen, a few dinoflagellate cyst species and acritarchs and the freshwater alga Botryococcus. The assemblage zone indicates a brackish to marine environment with a large input of terrestrial material. This is in accordance with the sedimentological data indicating various environments in a marginal shallow marine setting.

\section{Assemblage Zone 6: Perinopollenites elatoides}

Assemblage Zone 6, which is typical of the Skævdal and the Trefjord Bjerg Members (Fig. 17) is characterised by the abundance of the pollen Perinopollenites elatoides and the absence or scarcity of Spheripollenites subgranulatus. Overall, the palynomorph assemblage is dominated by different pollen species but dinoflagellate cysts are also significant, including Dissiliodinium sp., Phallocysta eumekes, Pareodinia halosa, and Kallospharidium sp.; acritarchs are also present.

At Albuen, in the south-eastern part of the basin, the lower boundary is placed some $10 \mathrm{~m}$ below the drowning surface that defines the top of the Nathorst Fjeld Member (Figs 3C, 17). The upper boundary of the assemblage zone at Albuen is placed at $434 \mathrm{~m}$ in the upper Trefjord Bjerg Member. Succeeding samples, just below the boundary between the Trefjord Bjerg Member and the Sortehat Formation, are referred to Assemblage Zone 7 , which is characteristic of the lower Sortehat Formation (Figs 3C, 17). At $437 \mathrm{~m}$, between these two sampled levels, is an erosional surface that is draped by well-rounded quartzite pebbles up to $3 \mathrm{~cm}$ across; this surface is defined as a sequence boundary (SB7 of Dam \& Surlyk 1998).

The Skævdal Member consists of bioturbated muddy sandstones and deposition probably took place in a low-energy shelf environment (Dam \& Surlyk 1995, 1998). Primary physical structures only occur locally and include wave ripple cross-lamination, cross-lamination and cross-bedding. Stratigraphic variations in the mud content suggests that the heavily bioturbated muddy sandstones were originally deposited as heteroliths (Dam \& Surlyk 1995, 1998).

The Skævdal Member is truncated by a prominent basinwide erosional unconformity, in places draped by a lag conglomerate. The unconformity marks a basinwide seawards shift in facies and is interpreted as a sequence boundary (SB6 of Dam \& Surlyk 1995, 1998). At Albuen, the sequence boundary is overlain by subtidal cross-bedded sandstones of the Trefjord Bjerg Member deposited in an extensive subtidal dune field.

The palynomorph Assemblage Zone 6 is indicative of deposition in a marine environment with a large input of terrigenous material. This is in accordance with the sedimentological data that indicate a shallow marine environment (Dam \& Surlyk 1995, 1998).

\section{Assemblage Zone 7: Botryococcus}

This assemblage is characterised by abundant Botryococcus. In a few samples near the lower boundary of the zone, both Botryococcus and dinoflagellate cysts occur in abundance, but the latter become rare upwards within the zone; the top of the zone is marked by the re-appearance of dinoflagellate cysts and the disappearance of Botryococcus. The depositional environment of this assemblage zone is discussed in detail in an accompanying paper (Koppelhus \& Hansen 2003, this volume).

\section{Deltoidospora Assemblage}

This assemblage is restricted to the Horsedal Member in the northern part of the basin (Figs 15-17). This member is made up of minor coarsening-upwards successions, 1-6 $\mathrm{m}$ thick, deposited in wave-dominated beaches or delta systems that prograded into an extensive lagoonal environment (Dam \& Surlyk 1995, 1998).

The palynomorph assemblage is overwhelmingly dominated by laevigate spores (pteridophyte spores) of the genus Deltoidospora and is suggestive of an enclosed swamp area (lagoon, pond, small lake) with a dense vegetation of ferns. This is in close agreement with the depositional environment suggested by sedimentary facies analysis (Dam \& Surlyk 1995, 1998).

\section{Discussion and conclusions}

Seven palynological assemblage zones have been recognised in the Rævekløft, Gule Horn and Ostreaelv 


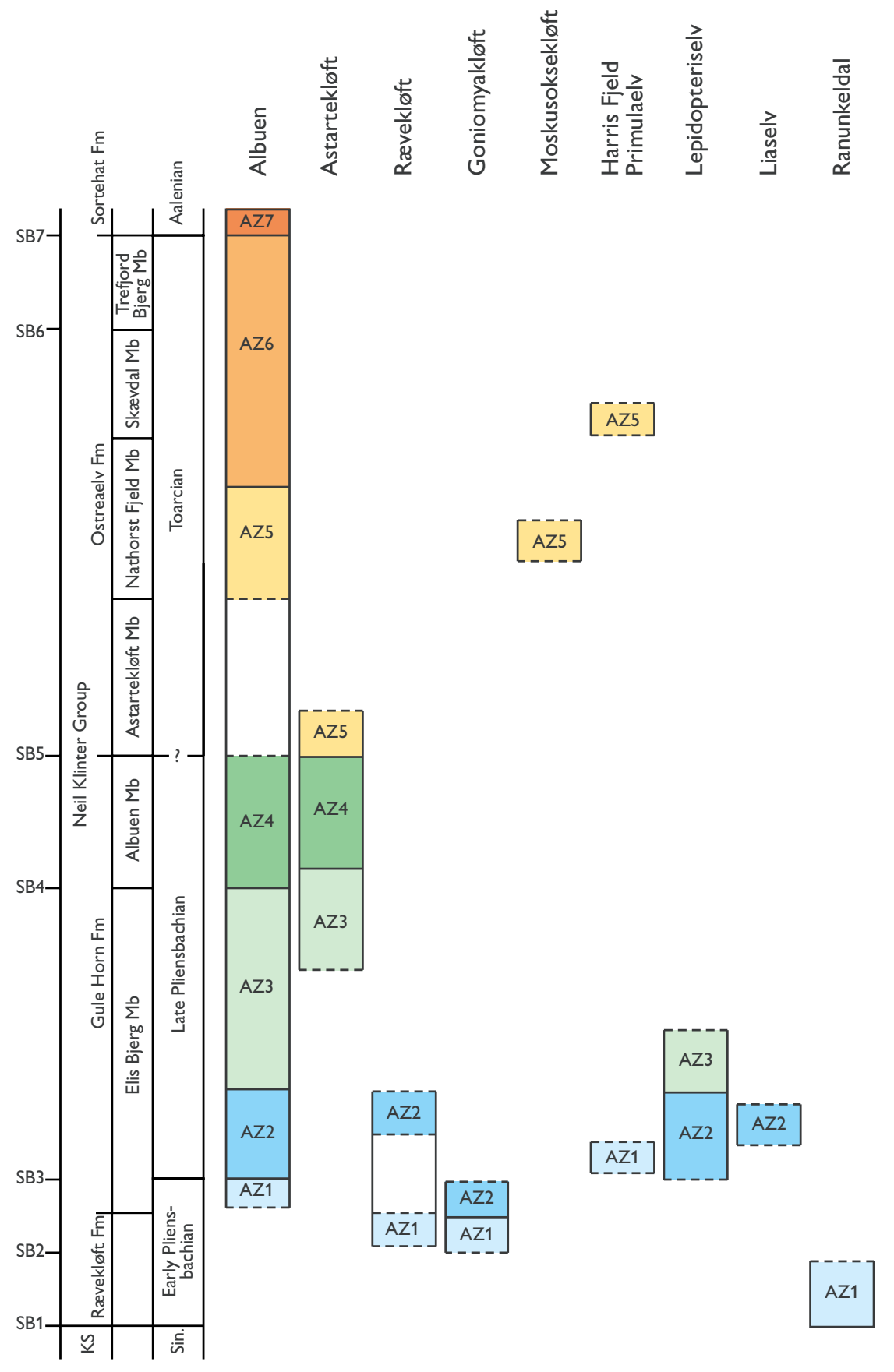

Fig. 18. Correlation diagram showing the stratigraphic distribution of the palynological assemblage zones (AZ1-7) at the studied locations (see Fig. 1). Note that the boundaries between Assemblage Zones 1 and 2 and between Assemblage Zones 3 and 4 are 'diachronous' relative to sequence boundaries SB3 and SB4 respectively. KS, Kap Stewart Group; Sin., Sinemurian.

Formations of the Neill Klinter Group (Fig. 17). Six of these are defined in this paper; the uppermost zone is defined by Koppelhus \& Hansen (2003, this volume) in an accompanying paper as it is most characteristic of the overlying Sortehat Formation, the uppermost formation of the Neill Klinter Group (Koppelhus \& Hansen 2003 , this volume). In addition, an assemblage termed the Deltoidospora Assemblage is defined here from the Horsedal section.
The seven palynological assemblage zones were all recognised primarily on the basis of data from the Albuen section but additional data from other localities suggest that the zones may have a basinwide distribution (Figs 17, 18). The palynological assemblages contain a diverse palynoflora, including 136 species. The assemblages indicate that the Neill Klinter Group spans the Early Pliensbachian to early Aalenian, without any major breaks in the stratigraphic record. The study 
Fig. 19. Diagram showing major palynoevents in the Neill Klinter Group compared to the Early Jurassic palynoevents recorded from the Halten Terrace, mid-Norwegian shelf (I. Throndsen, personal communication 1996). FAD, first appearance datum.

\begin{tabular}{|c|c|c|c|}
\hline \multirow{2}{*}{$\frac{\frac{\sqrt{\frac{\pi}{2}}}{\frac{0}{\frac{\pi}{4}}}}{\frac{\pi}{4}}$} & $\begin{array}{c}\text { Boreal ammonite } \\
\text { zones }\end{array}$ & $\begin{array}{l}\text { Palyno-events in } \\
\text { East Greenland }\end{array}$ & $\begin{array}{l}\text { Palyno-events on } \\
\text { the mid-Norwegian shelf }\end{array}$ \\
\hline & Opalinum & $\begin{array}{l}\text { Pareodinia halosa common } \\
\text { Botryococcus spp. acme }\end{array}$ & Wallodinium laganum acme \\
\hline \multirow{6}{*}{ 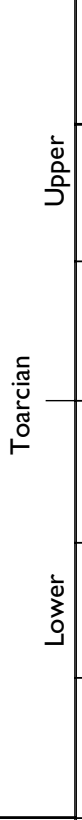 } & Levesquei & $\begin{array}{l}\text { Callialasporites dampieri FAD } \\
\text { Wallodinium laganum FAD }\end{array}$ & Callialasporites dampieri FAD \\
\hline & Thouarsense & Pareodinia halosa FAD & $\begin{array}{l}\text { Increasing Parvocysta sp. } \\
\text { Comparodinium sp. FAD } \\
\text { abundant Perinopollenites elatoides }\end{array}$ \\
\hline & Variabilis & Perinopollenites elatoides acme & Nannoceratopsis gracilis/senex acme \\
\hline & Bifrons & & $\begin{array}{l}\text { Sphaeromorph clusters acme } \\
\text { Chasmatosporites sp. } \\
\text { N. gracilis/senex acme }\end{array}$ \\
\hline & Falciferum & $\begin{array}{l}\text { Abundant } \\
\text { Cerebropollenites macroverrucosus }\end{array}$ & $\begin{array}{l}\text { Sphaeromorph clusters acme } \\
\text { Chasmatosporites sp. } \\
\text { N. gracilis/senex acme }\end{array}$ \\
\hline & Tenuicostatum & $\begin{array}{l}\text { Luehndea spinosa FAD } \\
\text { Cerebropollenites thiergartii } \\
\text { becomes rare } \\
\text { Spheripollenites acme }\end{array}$ & $\begin{array}{l}\text { Sphaeromorph clusters acme } \\
\text { Chasmatosporites sp. } \\
\text { N. gracilis/senex acme } \\
\text { Spheripollenites acme } \\
\text { Abundant-common L. spinosa }\end{array}$ \\
\hline \multirow{5}{*}{$\begin{array}{l}\bar{\Phi} \\
\grave{\alpha} \\
口\end{array}$} & Spinatum & $\begin{array}{l}\text { Only bisaccate pollen } \\
\text { Cerebropollenites thiergartii } \\
\text { dinoflagellate cysts }\end{array}$ & $\begin{array}{l}\text { Luehndea spinosa FAD } \\
\text { C. thiergartii present but becomes } \\
\text { rare in younger sediments }\end{array}$ \\
\hline & Margaritatus & $\begin{array}{l}\text { Parvocysta sp. FAD } \\
\text { Mancodinium semitabulatum } \\
\text { Nannoceratopsis senex/gracilis FAD }\end{array}$ & $\begin{array}{l}\text { Mancodinium semitabulatum } \\
\text { N. senex/gracilis FAD } \\
\text { Abundant-common Botryococcus spP }\end{array}$ \\
\hline & Davoei & Abundant Botryococcus spp. & Common acritarchs \\
\hline & Ibex & & \\
\hline & Jamesoni & & \\
\hline
\end{tabular}

shows that the palynomorph flora of the Neill Klinter Group is strongly influenced by the amount of organic matter derived from land plants and freshwater environments, yet the brackish and marine microplankton play a very important role in the interpretation of the environment and in establishing a palynostratigraphy for the group.

Comparing the sequence stratigraphic framework developed by Dam \& Surlyk $(1995,1998)$ with the dis- tribution of the palynological assemblages, it is clear that some of the major sequence stratigraphic and lithological boundaries are reflected by changes in the assemblages. Assemblage Zones 1-3 are characteristic of sequences SQ1-3. Figures 17 and 18 illustrate that the boundary between Assemblages 1 and 2 is diachronous on a regional scale with respect to the important sequence stratigraphic surfaces (e.g. SB3). Given that the sole difference between these two zones is the pres- 
ence/absence of marine dinoflagellates, such diachroneity is not surprising. It can be attributed to variations in terrestrial input and the dominance of the freshwater plume laterally along the basin margin.

The transition from Assemblage Zone 2 to Assemblage Zone 3 is marked by a decrease in dinoflagellate cysts which coincides with a gradual overall change from a dominance of subtidal sand sheet deposits to a dominance of tidal channel deposits in the upper part of the Elis Bjerg Member (Figs 3A, 17; Dam \& Surlyk 1998). The strengthening of the terrestrial signal recorded by the change in the palynological assemblage is thus in accordance with the sedimentological record.

At Albuen, sequence boundary SB4 separates Assemblage Zones 3 and 4; at Astartekløft, however, a sample from a few metres above the sequence boundary is referred to Assemblage Zone 3. This may be due to reworking of the uppermost sediments of the Elis Bjerg Member in the underlying sequence. Palynological data from the Astartekløft section suggest that SB5 separates Assemblage Zones 4 and 5, whereas the transition from Assemblage Zone 5 to 6 appears to be diachronous (Fig. 17).

Sequence boundary SB7 separates Assemblage Zones 6 and 7 (Fig. 17). With respect to the sequence stratigraphic interpretation given by Dam \& Surlyk (1995), an important conclusion of this study is that Assemblage Zone 7 , characteristic of the lower part of the overlying Sortehat Formation (Koppelhus \& Hansen 2003, this volume), also occurs in the uppermost few metres of the Trefjord Bjerg Member at Albuen, above a laterally persistent erosional surface with a conglomerate lag (Figs 3C, 17). At other localities, a thin conglomerate layer separates the Trefjord Bjerg Member and the Sortehat Formation. Dam \& Surlyk (1995) interpreted the Trefjord Bjerg Member - Sortehat Formation boundary as a coalesced sequence boundary and transgressive surface. However, the palynological data suggest that at Albuen the sequence boundary should be placed beneath this boundary, at the conglomerate-draped erosional surface, and thus that the uppermost sandstones (c. $3 \mathrm{~m}$ thick) of the Trefjord Bjerg Member represent a thin lowstand or transgressive package (Figs 3C, 17). Moreover, the palynological data suggest that the inferred major flooding surfaces in the sequence stratigraphic analysis (i.e. base Albuen Member and base Sortehat Formation), may in fact record partial isolation of the embayment from the seaway between Norway and Greenland causing a freshwater to brackish environment to develop. This would also explain the lack of tidal indicators in the Albuen Member. If this is the case, the
Albuen Member does not represent transgressive and highstand deposits in a sequence stratigraphic sense, but rather a period of physical isolation of the basin from the sea.

The palynostratigraphy has proven to be an important tool in confirming the high-resolution sequence stratigraphic correlation between East Greenland and the Halten Terrace of the mid-Norwegian shelf proposed by Dam \& Surlyk (1995). This detailed palynological study should make it possible to correlate to other localities in the North Atlantic and to the mid-Norwegian area and the northern part of the North Sea. The pattern of events seen in the East Greenland material is mirrored by data from the Halten Terrace. Thus, according to I. Throndsen (personal communication 1996), the Pliensbachian is characterised by common to abundant Botryococcus; this is followed by the incoming of the dinoflagellate cysts Nannoceratopsis gracilis, N. senex and Mancodinium semitabulatum together with common to abundant Cerebropollenites thiergartii pollen and abundant bisaccate pollen in the Upper Pliensbachian (Fig. 19). The dinoflagellate cyst Luebndea spinosa occurs in the uppermost Pliensbachian and lowermost Toarcian together with Nannoceratopsis gracilis and $N$. senex followed by an acme of Spheripollenites subgranulatus together with the sphaeromorph clusters. In the Upper Toarcian, the dinoflagellate cyst Parvocysta complex appears together with abundant Perinopollenites elatoides pollen and the first Callialasporites dampieri appear together with the dinoflagellate cyst Wallodinium in the lowermost Aalenian.

\section{Acknowledgements}

The work carried out in connection with this project by E.B.K. was supported by a grant from the EFP-93 Projects 1313/93-0010 and 0017. The work of G.D. has been supported by BP Exploration Operating Company Limited, London, and the Carlsberg Foundation. The manuscript was read by Karen Dybkjær, James B. Riding, Jon R. Ineson and Finn Surlyk who offered many helpful suggestions. In particular, we thank Ingar Throndsen who placed unpublished data from the Halten Terrace at our disposal, Henrik Nøhr-Hansen for patient assistance with the range charts and Jon R. Ineson for careful editing of the manuscript. 


\section{References}

Batten, D.J., Koppelhus, E.B. \& Nielsen, L.H. 1994: Uppermost Triassic to Middle Jurassic palynofacies and palynomiscellanea in the Danish Basin and Fennoscandian Border Zone. Cahiers de Micropaléontologie 9, 21-45.

Bjærke, T. 1980a: Mesozoic palynology of Svalbard V. Dinoflagellates from the Agardhfjellet Member (Middle and Upper Jurassic) in Spitsbergen. Norsk Polarinstitutt Skrifter 172, 145-167.

Bjærke, T. 1980b: Mesozoic palynology of Svalbard IV. Toarcian dinoflagellates from Spitsbergen. Palynology 4, 57-77.

Bromley, R.G. \& Asgaard, U. 1979: Triassic freshwater ichnocoenoses from Carlsberg Fjord, East Greenland. Palaeogeography, Palaeoclimatology, Palaeoecology 28, 39-80.

Callomon, J.H. 1961: The Jurassic system in East Greenland. In: Raasch, G.O. (ed.): Geology of the Arctic 1, 258-268. Toronto: University of Toronto Press.

Clemmensen, L.B. 1978a: Alternating aeolian, sabkha and shallow-lake deposits from the Middle Triassic Gipsdalen Formation, Scoresby Land, East Greenland. Palaeogeography, Palaeoclimatology, Palaeoecology 24, 111-135.

Clemmensen, L.B. 1978b: Lacustrine facies and stromatolites from the Middle Triassic of East Greenland. Journal of Sedimentary Petrology 48, 1111-1128.

Clemmensen, L.B. 1979: Triassic lacustrine red-beds and palaeoclimate: the 'Buntsandstein' of Helgoland and the Malmros Klint Member of East Greenland. Geologische Rundschau 68 , 748-774.

Clemmensen, L.B. 1980a: Triassic rift sedimentation and palaeogeography of central East Greenland. Bulletin Grønlands Geologiske Undersøgelse 136, 72 pp.

Clemmensen, L.B. 1980b: Triassic lithostratigraphy of East Greenland between Scoresby Sund and Kejser Franz Josephs Fjord. Bulletin Grønlands Geologiske Undersøgelse 139, 56 pp.

Dam, G. 1990a: Taxonomy of trace fossils from the shallow marine Lower Jurassic Neill Klinter Formation, East Greenland. Bulletin of the Geological Society of Denmark 38, 119-144.

Dam, G. 1990b: Palaeoenvironmental significance of trace fossils from the shallow marine Lower Jurassic Neill Klinter Formation, East Greenland. Palaeogeography, Palaeoclimatology, Palaeoecology 79, 221-248.

Dam, G. 1991: A sedimentological analysis of the continental and shallow marine Upper Triassic to Lower Jurassic succession in Jameson Land, East Greenland, 243 pp. Unpublished Ph.D. thesis, University of Copenhagen, Denmark.

Dam, G. \& Surlyk, F. 1992: Forced regressions in a large waveand storm-dominated anoxic lake, Rhaetian-Sinemurian Kap Stewart Formation, East Greenland. Geology 20, 749-752.

Dam, G. \& Surlyk, F. 1993: Cyclic sedimentation in a large waveand storm-dominated anoxic lake; Kap Stewart Formation (Rhaetian-Sinemurian), Jameson Land, East Greenland. In: Posamentier, H.W. et al. (eds): Sequence stratigraphy and facies associations. International Association of Sedimentologists Special Publication 18, 419-448.

Dam, G. \& Surlyk, F. 1995: Sequence stratigraphic correlation of Lower Jurassic shallow marine and paralic successions across the Greenland-Norway seaway. In: Steel, R.J. et al. (eds) Sequence stratigraphy on the Northwest European margin. Norwegian Petroleum Society (NPF) Special Publication 5, 483-509.

Dam, G. \& Surlyk, F. 1998: Stratigraphy of the Neill Klinter Group; a Lower - lower Middle Jurassic tidal embayment succession, Jameson Land, East Greenland. Geology of Greenland Survey Bulletin 175, 80 pp.

Doyle, P. 1991: Belemnites from the Lower Jurassic of East Greenland and their biostratigraphical and biogeographical significance. Bulletin of the Geological Society of Denmark 39, 123-141.

Dybkjær, K. 1991: Palynological zonation and palynofacies investigation of the Fjerritslev Formation (Lower Jurassic - basal Middle Jurassic) in the Danish Subbasin. Danmarks Geologiske Undersøgelse Serie A 30, 150 pp.

Engkilde, M. 1994: The Middle Jurassic Vardekløft Formation, East Greenland: depositional environments and sequence stratigraphy of shallow marine sandstones deposited in a lowgradient epeiric seaway, 207 pp. Unpublished Ph.D. thesis, University of Copenhagen, Denmark.

Feist-Burkhardt, S. \& Monteil, E. 1994: Wallodinium cylindricum and 'Wallodinium elongatum': stratigraphic problem and taxonomical solution. Cahiers de Micropaléontologie 9, 5-15.

Fenton, J. \& Riding, J.B. 1987: Kekryphalospora distincta gen. et sp. nov., a trilete spore from the Lower and Middle Jurassic of North-West Europe. Pollen et Spores 19, 427-434.

Guy-Ohlson, D. 1988: Toarcian palynostratigraphical correlations within and between different biogeographical provinces. In: Rocha, R.B. \& Soares, A.F. (eds): 2nd International Symposium on Jurassic Stratigraphy (Lisbon 1987) 1, 807-820. Lisbon: Universidade Nova de Lisboa.

Guy-Ohlson, D. 1992: Botryococcus as an aid in the interpretation of palaeoenvironment and depositional processes. Review of Palaeobotany and Palynology 71, 1-15.

Harris, T.M. 1931: Rhaetic floras. Biological Reviews of the Cambridge Philosophical Society 6, 133-162.

Koppelhus, E.B. \& Batten, D.J. 1996: Applications of a palynomorph zonation to a series of short borehole sections, Lower to Middle Jurassic, Øresund, Denmark. In: Jansonius, J. \& McGregor, D.C. (eds): Palynology: principles and applications. American Association of Stratigraphic Palynologists Foundation 2, 779-793.

Koppelhus, E.B. \& Hansen, C.F. 2003: Palynostratigraphy and palaeoenvironment of the Middle Jurassic Sortehat Formation (Neill Klinter Group), Jameson Land, East Greenland. In: Ineson, J.R. \& Surlyk, F. (eds): The Jurassic of Denmark and Greenland. Geological Survey of Denmark and Greenland Bulletin 1, 777-811 (this volume).

Koppelhus, E.B. \& Nielsen, L.H. 1994: Palynostratigraphy and palaeoenvironments of the Lower to Middle Jurassic Baga Formation of Bornholm, Denmark. Palynology 18, 139-194.

Larsen, H.C. \& Marcussen, C. 1992: Sill-intrusion, flood basalt emplacement and deep crustal structure of the Scoresby Sund region, East Greenland. In: Storey, B.C., Alabaster, T. \& Pankhurst, R.J. (eds): Magmatism and the causes of continental break-up. Geological Society Special Publication 
(London) 68, 365-386.

Lund, J.J. \& Pedersen, K.R. 1985: Palynology of the marine Jurassic formations in the Vardekløft ravine, Jameson Land, East Greenland. Bulletin of the Geological Society of Denmark 33, 371-400.

Morgenroth, P. 1970: Dinoflagellate cysts from the Lias Delta of Lühnde/Germany. Neues Jahrbuch für Geologie und Paläontologie Abhandlungen 136, 345-359.

Nøhr-Hansen, H. 1993: Dinoflagellate cyst stratigraphy of the Barremian to Albian, Lower Cretaceous, North-East Greenland. Bulletin Grønlands Geologiske Undersøgelse 166, 171 pp.

Poulsen, N.E. 1996: Dinoflagellate cysts from marine Jurassic deposits of Denmark and Poland. American Association of Stratigraphic Palynologists Contributions Series 31, 227 pp.

Prauss, M. 1987: Nannoceratopsis triangulata n.sp. - eine neue Dinozysten-Spezies aus dem Obertoarcium von NW-Deutschland. Neues Jahrbuch für Geologie und Paläontologie Abhandlungen 176, 129-136.

Riding, J.B. \& Thomas, J.E. 1992: Dinoflagellate cysts of the Jurassic System. In: Powell, A.J. (ed.): A stratigraphic index of dinoflagellate cysts, 7-97. British Micropalaeontological Society Publication Series. London: Chapman \& Hall.

Riding, J.B., Walton, W. \& Shaw, D. 1991: Toarcian to Bathonian (Jurassic) palynology of the Inner Hebrides, Northwest Scotland. Palynology 15, 115-179.

Rosenkrantz, A. 1929: Preliminary account of the geology of the Scoresby Sound District. Meddelelser om Grønland 73(2), 135-154.

Rosenkrantz, A. 1934: The Lower Jurassic rocks of East Greenland, Part I. Meddelelser om Grønland 110(1), 150 pp.

Seidenkrantz, M.-S., Koppelhus, E.B. \& Ravn-Sørensen, H. 1993: Biostratigraphy and palaeoenvironmental analysis of a Lower to Middle Jurassic succession on Anholt, Denmark. Journal of Micropalaeontology 12, 201-218.

Smelror, M. \& Below, R. 1992: Dinoflagellate biostratigraphy of the Toarcian to Lower Oxfordian (Jurassic) of the Barents Sea region. Norwegian Petroleum Society (NPF) Special Publication 2, 495-513.

Surlyk, F. 1977a: Mesozoic faulting in East Greenland. In: Frost, R.T.C. \& Dikkers, A.J. (eds): Fault tectonics in NW Europe. Geologie en Mijnbouw 56, 311-327.

Surlyk, F. 1977b: Stratigraphy, tectonics and palaeogeography of the Jurassic sediments of the areas north of Kong Oscars Fjord, East Greenland. Bulletin Grønlands Geologiske Undersøgelse 123, 56 pp.

Surlyk, F. 1978: Jurassic basin evolution of East Greenland. Nature 274, 130-133.

Surlyk, F. 1990a: Timing, style and sedimentary evolution of Late Palaeozoic - Mesozoic extensional basins of East Greenland. In: Hardman, R.F.P. \& Brooks, J. (eds): Tectonic events respon- sible for Britain's oil and gas reserves. Geological Society Special Publications (London) 55, 107-125.

Surlyk, F. 1990b: A Jurassic sea-level curve for East Greenland. Palaeogeography, Palaeoclimatology, Palaeoecology 78, 71-85.

Surlyk, F. 1991: Sequence stratigraphy of the Jurassic - lowermost Cretaceous of East Greenland. American Association of Petroleum Geologists Bulletin 75, 1468-1488.

Surlyk, F. 2003: The Jurassic of East Greenland: a sedimentary record of thermal subsidence, onset and culmination of rifting. In: Ineson, J.R. \& Surlyk, F. (eds): The Jurassic of Denmark and Greenland. Geological Survey of Denmark and Greenland Bulletin 1, 659-722 (this volume).

Surlyk, F., Callomon, J.H., Bromley, R.G. \& Birkelund, T. 1973: Stratigraphy of the Jurassic - Lower Cretaceous sediments of Jameson Land and Scoresby Land, East Greenland. Bulletin Grønlands Geologiske Undersøgelse 105, 76 pp. (also Meddelelser om Grønland 193(5)).

Surlyk, F., Clemmensen, L.B. \& Larsen, H.C. 1981: Post-Paleozoic evolution of the East Greenland continental margin. In: Kerr, J.W., Fergusson, A.J. \& Machan, L.C. (eds): Geology of the North Atlantic borderlands. Canadian Society of Petroleum Geologists Memoir 7, 611-645.

Surlyk, F., Piasecki, S., Rolle, F., Thomsen, E. \& Wrang, P. 1984: The Permian basin of East Greenland. In: Spencer, A. et al. (eds): Petroleum Geology of the North European Margin, 303-315. London: Graham \& Trotman for the Norwegian Petroleum Society (NPF).

Surlyk, F., Hurst, J.M., Piasecki, S., Rolle, F., Scholle, P.A., Stemmerik, L. \& Thomsen, E. 1986: The Permian of the western margin of the Greenland Sea - a future exploration target. In: Halbouty, M.T. (ed.): Future petroleum provinces of the world. American Association of Petroleum Geologists Memoir 40, 629-659.

Sykes, R.M. 1974: Sedimentological studies in southern Jameson Land, East Greenland. II. Offshore-estuarine regressive sequences in the Neill Klinter Formation (PliensbachianToarcian). Bulletin of the Geological Society of Denmark 23, 213-224.

Underhill, J.R. \& Partington, M.A. 1994: Use of genetic sequence stratigraphy in defining and determining a regional tectonic control on the 'Mid-Cimmerian Unconformity' - implications for North Sea basin development and the global sea-level chart. In: Weimer, P. \& Posamentier, H.W. (eds): Siliciclastic sequence stratigraphy. Recent developments and applications. American Association of Petroleum Geologists Memoir 58, 449-484

Wall, D. 1965: Microplankton, pollen, and spores from the Lower Jurassic in Britain. Micropaleontology 11, 151-190.

Ziegler, P.A. 1988: Evolution of the Arctic - North Atlantic and the western Tethys. American Association of Petroleum Geologists Memoir 43, 198 pp. 


\section{Appendix 1: \\ List of all recorded palynomorph taxa}

\section{Miospores:}

Anapiculatisporites sp.

A. telephorus (Pautsch) Klaus 1960

Annulispora folliculosa (Rogalska) de Jersey 1959

Apiculatisporites parvispinosus (Leschik) Schulz 1963

A. sp.

Araucariacites australis Cookson 1947

Baculatisporites sp. (Plate 1, fig. 12)

B. wellmanii (Couper) Krutzsch 1959

Bisaccates indeterminate (Plate 2, fig. 9)

Callialasporites dampieri (Balme) Dev 1961 (Plate 2, fig. 5)

C. microvelatus Schulz 1966

C. minus (Tralau) Guy 1971 (Plate 2, fig. 3)

C. sp.

C. turbatus (Balme) Schulz 1967

Calamospora tener (Leschik) Mädler 1964

Camarozonozporites rudis (Leschik) Klaus 1960

C. sp.

Campenia sp.

Cerebropollenites macroverrucosus (Thiergart) Schulz 1967

(Plate 3, fig. 4)

C. sp.

C. thiergartii Schulz 1967 (Plate 3, fig. 1)

Chasmatosporites apertus Nilsson 1958 (Plate 3, fig. 5)

C. elegans Nilsson 1958

C. hians Nilsson 1958

C. major Nilsson 1958 (Plate 3, fig. 7)

C. minor Nilsson 1958

C. sp.

Chomotriletes minor (Kedves) Pocock 1970

C. sp.

Cibotiumspora jurienensis (Balme) Filatoff 1975

Cingulizonates inequalis (Mädler) Lund 1977

Conbaculatisporites mesozoicus Klaus 1960

C. sp.

Corollina meyeriana (Klaus) Venkatachala \& Goczan 1964

C. sp.

C. torosus (Reissinger) Cornet \& Traverse 1975 (Plate 3, fig. 2)

Deltoidospora minor (Couper) Pocock 1970

D. spp. (Plate 1, fig. 1)

Densoisporites scanicus Tralau 1968 (Plate 1, fig. 9)

D. velatus Weyland \& Krieger 1953

Densosporites sp.

D. variabilis (Waltz) Potonié \& Kremp 1956

Eucommiidites major Schulz 1967

E. troedsonii Erdtman 1948
Exesipollenites tumulus Balme 1957

Foraminisporis jurassicus Schulz 1967

Fungal spores

Iraquispora sp.

Ischyosporites crateris Balme 1957 (Plate 1, fig. 7)

I. sp.

I. variegatus (Couper) Schulz 1967 (Plate 2, fig. 1)

Kekryphalospora distincta Fenton \& Riding 1987 (Plate 1, fig. 3)

Kraeuselisporites reissingeri (Harris) Morbey 1975 (Plate 1, fig. 5)

Leptolepidites major

L. sp. (Plate 1, fig. 4)

Limbosporites lundbladii Nilsson 1958

Lycopodiacidites rugulatus (Couper) Schulz 1967 (Plate 2, fig. 4) Manumia delcourtii (Pocock) Dybkjær 1991 (Plate 2, fig. 2)

Marattisporites scabratus Couper 1958

Megaspore fragments

Monosaccate pollen

Monosulcites punctatus Orlowska-Zwolinska 1966 (Plate 2, fig. 6)

Murospora sp.

Neoraistrickia gristhorpensis (Couper) Tralau 1967

N. sp.

N. taylori Playford \& Dettmann 1965

Ovalispollis ovalis Krutzsch 1955

Perinopollenites elatoides Couper 1958 (Plate 3, fig. 3)

Perinosporites thuringiacus Schulz 1962

Pinuspollenites minimus (Couper) Kemp 1970 (Plate 2, fig. 8)

Polycingulatisporites circulus Simoncsics \& Kedves 1961

P. triangularis (Bolkhovitina) Playford \& Dettmann 1965

Quadraeculina anellaeformis Malyavkina 1949 (Plate 2, fig. 7)

Retitriletes austroclavatoides (Cookson) Döring et al. 1963

R. clavatoides (Couper) Döring et al. 1963

R. semimuris (Danzé-Corsin \& Laveine) McKellar 1974

R. sp. (Plate 1, fig. 8)

Ricciisporites tuberculatus Lundblad 1954

Rogalskaisporites cicatricosus (Rogalska) Danzé-Corsin \& Laveine 1963 (Plate 1, fig. 10)

Sculptisporites aulosenensis (Schulz) Koppelhus 1992

Sestrosporites pseudoalveolatus (Couper) Dettmann 1963

Spheripollenites psilatus Couper 1958

S. subgranulatus Couper 1958 (Plate 3, figs 6, 8)

Staplinisporites caminus (Balme) Pocock 1970 (Plate 1, fig. 11) Stereisporites antiquasporites (Wilson \& Webster) Dettmann 1963 Stereisporites stereoides (Potonié \& Venitz) H.D. Pflug in: Thomson \& Pflug 1953

S. sp.

Striatella jurassica Mädler 1964

S. parva (Li \& Shang) Filatoff \& Price 1988

S. scania (Nilsson) Filatoff \& Price 1988

S. seebergensis Mädler 1964 (Plate 1, fig. 2)

$S$. spp.

Striate pollen 
Taeniasporites rhaeticus Schulz 1967

T. sp.

Taurocusporites verrucatus Schulz 1967 (Plate 1, fig. 6)

Tigrisporites microrugulatus Schulz 1967

T. sp.

Todisporites major Couper 1958

T. minor Couper 1958

T. sp.

Triletes sp.

Tripartina variabilis Malyavkina 1949

Uvaesporites argenteaeformis (Bolkhovitina) Schulz 1967

U. sp.

Vesicaspora fuscus (Pautsch) Morbey 1975

Vitreisporites pallidus (Reissinger) Nilsson 1958

V. sp.

Vittatina sp.

Zebrasporites interscriptus (Thiergart) Klaus 1960

\section{Phytoplankton:}

Acritarch spp.

Baltisphaeridium sp.

Beaumontella caminuspina (Wall) Below 1987

B. delicata (Wall) Below 1987

B. sp.

Botryococcus spp. (Plate 6, figs 6, 7)

Celyphus rallus Batten 1985 (Plate 7, fig. 1)

C. spp.

Crassosphaera sp.

Cymatiosphaera sp.

Dapcodinium sp.

Dinocyst sp. (Plate 4, figs 8, 9)

Dissiliodinium sp. (Plate 6, figs 4, 5)

Kallosphaeridium sp.

Lecaniella foveata Singh 1971 (Plate 7, fig. 5)

L. spp.

Leiofusa jurassica Cookson \& Eisenack 1958 (Plate 7, fig. 2)

Leiosphaeridia spp.

Limbicysta bjaerkei (Smelror) MacRae et al. 1996 (Plate 6, figs 1-3)

Luehndea spinosa Morgenroth 1970 (Plate 5, fig. 5)

Mancodinium semitabulatum Morgenroth 1970 (Plate 5, figs 1, 2)

M. sp.

Mendicodinium groenlandicum (Pocock \& Sarjeant) Davey 1979

M. reticulatum Morgenroth 1970 (Plate 5, figs 3, 4)

M. sp.
Micrhystridium exilium Wall 1965

M. fragile Deflandre 1937

M. intromittum Wall 1965

M. lymensis Wall 1965

M. spp.

M. stellatum Deflandre 1942

M. wattonense Wall 1965

Nannoceratopsis ambonis (Drugg) Riding 1984 (Plate 4, fig. 4)

N. dictyoambonis Riding 1984

N. gracilis Alberti emend. van Helden 1977 (Plate 4, figs 1, 3)

N. plegas Drugg 1978

N. senex van Helden 1977 (Plate 4, fig. 2)

N. sp.

N. triangulata Prauss 1987

N. triceras Drugg 1978

Pareodinia halosa (Filatoff) Prauss 1989 (Plate 4, fig. 7)

Parvocysta barbata Bjærke 1980

P. nasuta Bjærke 1980

P. sp.

Phallocysta eumekes Dörhöfer \& Davies 1980 (Plate 4, figs 5, 6)

P. elongata (Beju) Riding 1994

Pterospermella spp.

Scriniocassis sp.

Susadinium scrofoides (Dörhöfer \& Davies) Below 1987

Tasmanites sp.

Tetraporina compressa Kondrat'ev 1963 (Plate 7, fig. 6)

Valvaeodinium armatum Morgenroth 1970

V. spp.

Veryhachium collectum Wall 1965 (Plate 7, fig. 3)

$V$. formosum Stockmans \& Williere 1960 (Plate 7, fig. 4)

V. irregulare de Jekhowsky 1961

V. reductum (Deunff) de Jekhowsky 1961

V. sp.

V. trispinosum (Eisenack) Deunff 1954

Wallodinium laganum Feist-Burkhardt \& Monteil 1994

(Plate 5, fig. 6)

W. spp.

\section{Others:}

Foraminifera spp.

Foraminiferal linings (Plate 7, fig. 7)

Haplophragmoides spp.

Miscellaneous 
Plates 1-7 


\section{Plate 1}

Palynomorphs from the Neill Klinter Group at the Albuen section. The scale bar is 10 microns. For each of the illustrated specimens (Plates 1-7), the England Finder Reference (EFR) is given.

Fig. 1. Deltoidospora sp.

Sample 405414-3, EFR S291.

Fig. 2. Striatella seebergensis.

Sample 405466-3, EFR D34.

Fig. 3. Kekryphalospora distincta.

Sample 405466-3, EFR J383.

Fig. 4. Leptolepidites sp.

Sample 405423-3, EFR T40.

Fig. 5. Kraeuselisporites reissingeri.

Sample 405419-3, EFR D294.

Fig. 6. Taurocusporites verrucatus.

Sample 405466-3, EFR H273.

Fig. 7. Ischyosporites crateris.

Sample 405449-3, EFR W29.

Fig. 8. Retitriletes sp.

Sample 405420-3, EFR P50.

Fig. 9. Densoisporites scanicus.

Sample 405449-3, EFR P19.

Fig. 10. Rogalskaisporites cicatricosus.

Sample 405419-3, EFR L513.

Fig. 11. Staplinisportes caminus.

Sample 405449-3, EFR J462.

Fig. 12. Baculatisporites sp.

Sample 405414-3, EFR T353. 

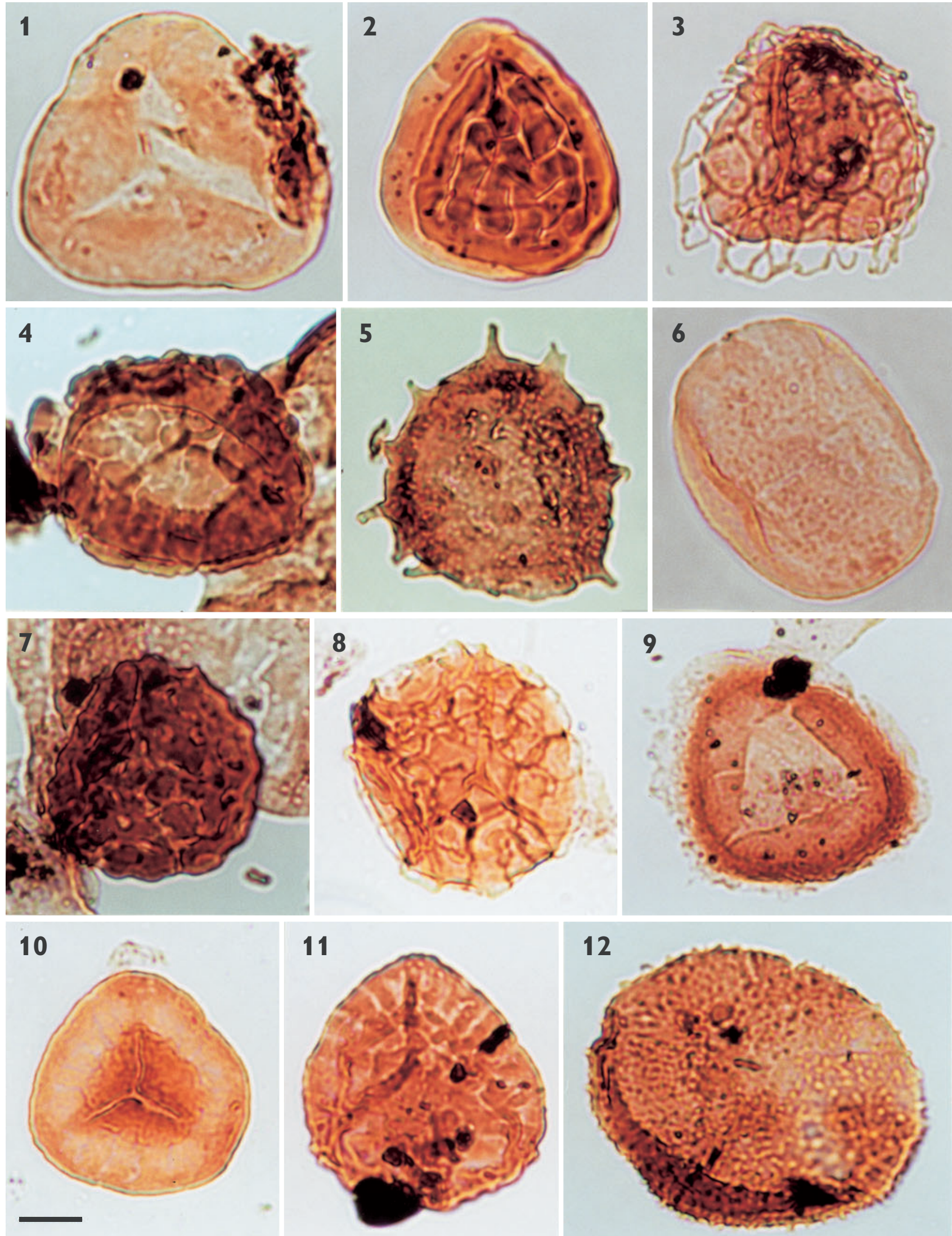


\section{Plate 2}

Palynomorphs from the Neill Klinter Group at the Albuen section. The scale bar is 10 microns.

Fig. 1. Ischyosporites variegatus.

Sample 405464-3, EFR G43.

Fig. 2. Manumia delcourti.

Sample 405449-3, EFR V244.

Fig. 3. Callialasporites minus.

Sample 405449-3, EFR J291.

Fig. 4. Lycopodiacidites rugulatus.

Sample 405401-4, EFR Z263.

Fig. 5. Callialasporites dampieri.

Sample 405449-3, EFR J203.

Fig. 6. Monosulcites punctatus.

Sample 405414-3, EFR T31.

Fig. 7. Quadraeculina anellaeformis.

Sample 405414-3, EFR K431.

Fig. 8. Pinuspollenites minimus.

Sample 405420-2, EFR V212.

Fig. 9. Bisaccate sp., full dimensions $90 \times 70$ microns.

Sample 405418-3, EFR P462. 


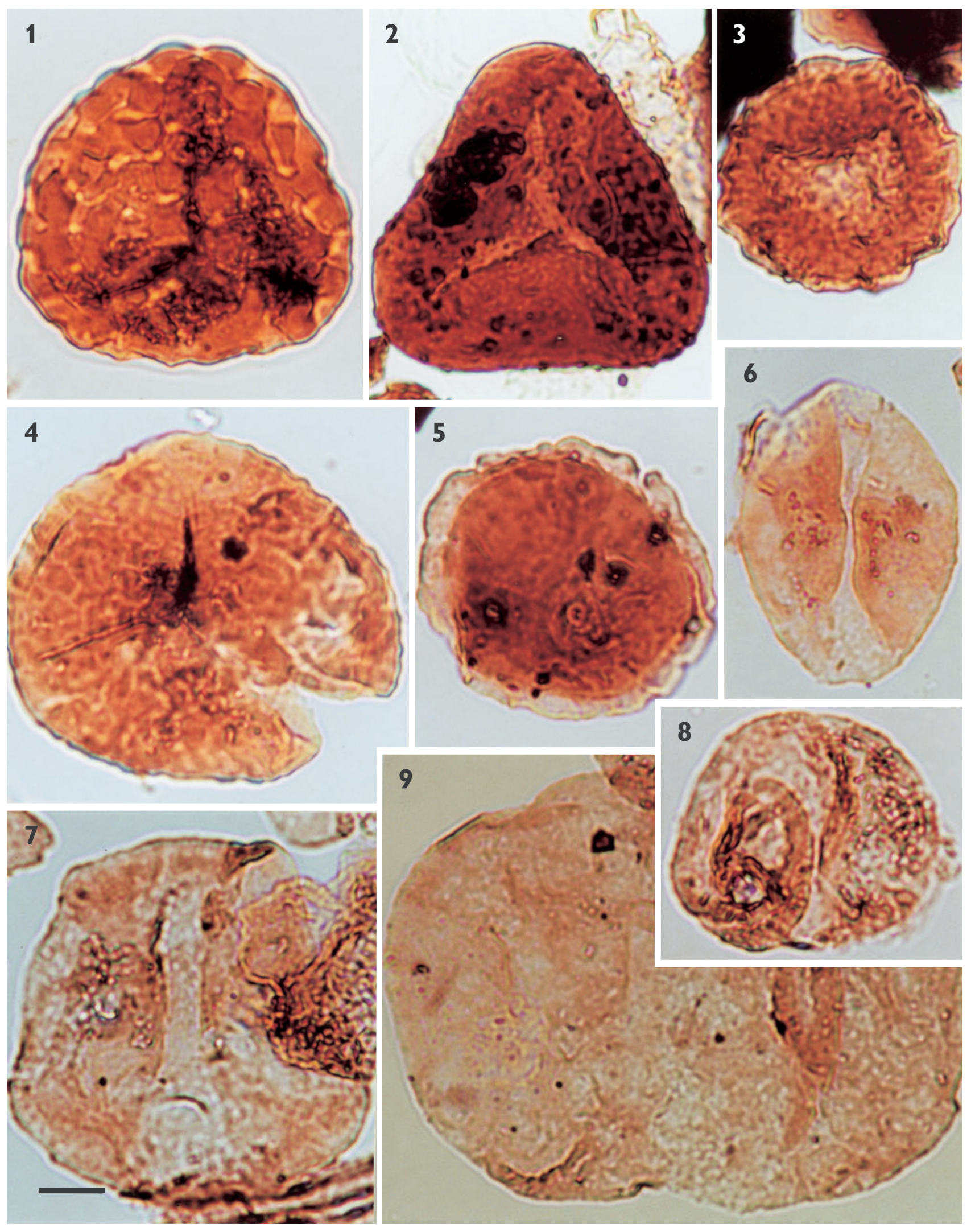




\section{Plate 3}

Palynomorphs from the Neill Klinter Group at the Albuen section. The scale bar is 10 microns.

Fig. 1. Cerebropollenites thiergartii.

Sample 405401-4, EFR U252.

Fig. 2. Corollina torosus.

Sample 405466-3, EFR D171.

Fig. 3. Perinopollenites elatoides.

Sample 405453-3, EFR G243.

Fig. 4. Cerebropollenites macroverrucosus.

Sample 405454-3, EFR Y303.

Fig. 5. Chasmatosporites apertus.

Sample 405401-4, EFR Y363.

Fig. 6. Spheripollenites subgranulatus.

Sample 405459-3, EFR N293.

Fig. 7. Chasmatosporites major.

Sample 405423-3, EFR F51.

Fig. 8. Spheripollenites subgranulatus.

Sample 405459-3, EFR N20. 

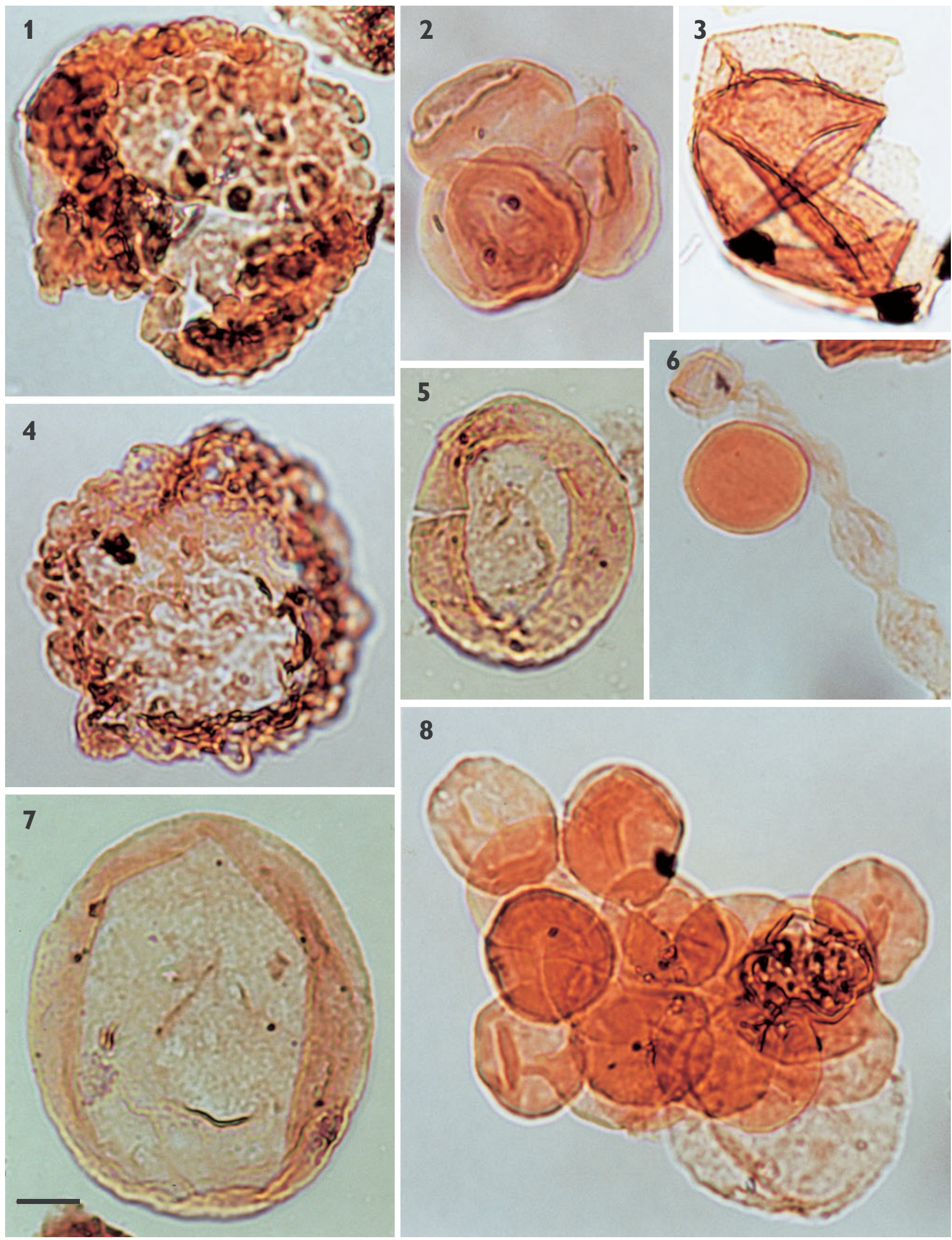


\section{Plate 4}

Palynomorphs from the Neill Klinter Group at the Albuen section. The scale bar is 10 microns.

Fig. 1. Nannoceratopsis gracilis.

Sample 405449-3, EFR N20.

Fig. 2. N. senex.

Sample 405466-3, EFR K211.

Fig. 3. N. gracilis.

Sample 405414-3, EFR O404.

Fig. 4. N. ambonis.

Sample 405453-3, EFR F383.

Fig. 5. Phallocysta eumekes.

Sample 405426-3, EFR V47.

Fig. 6. P. eumekes.

Sample 405459-3, EFR Y56.

Fig. 7. Pareodinia halosa.

Sample 405454-3, EFR V314.

Fig. 8. Dinoflagellate sp.

Sample 405419-3, EFR D40.

Fig. 9. Dinoflagellate sp.

Sample 405453-3, EFR E272. 


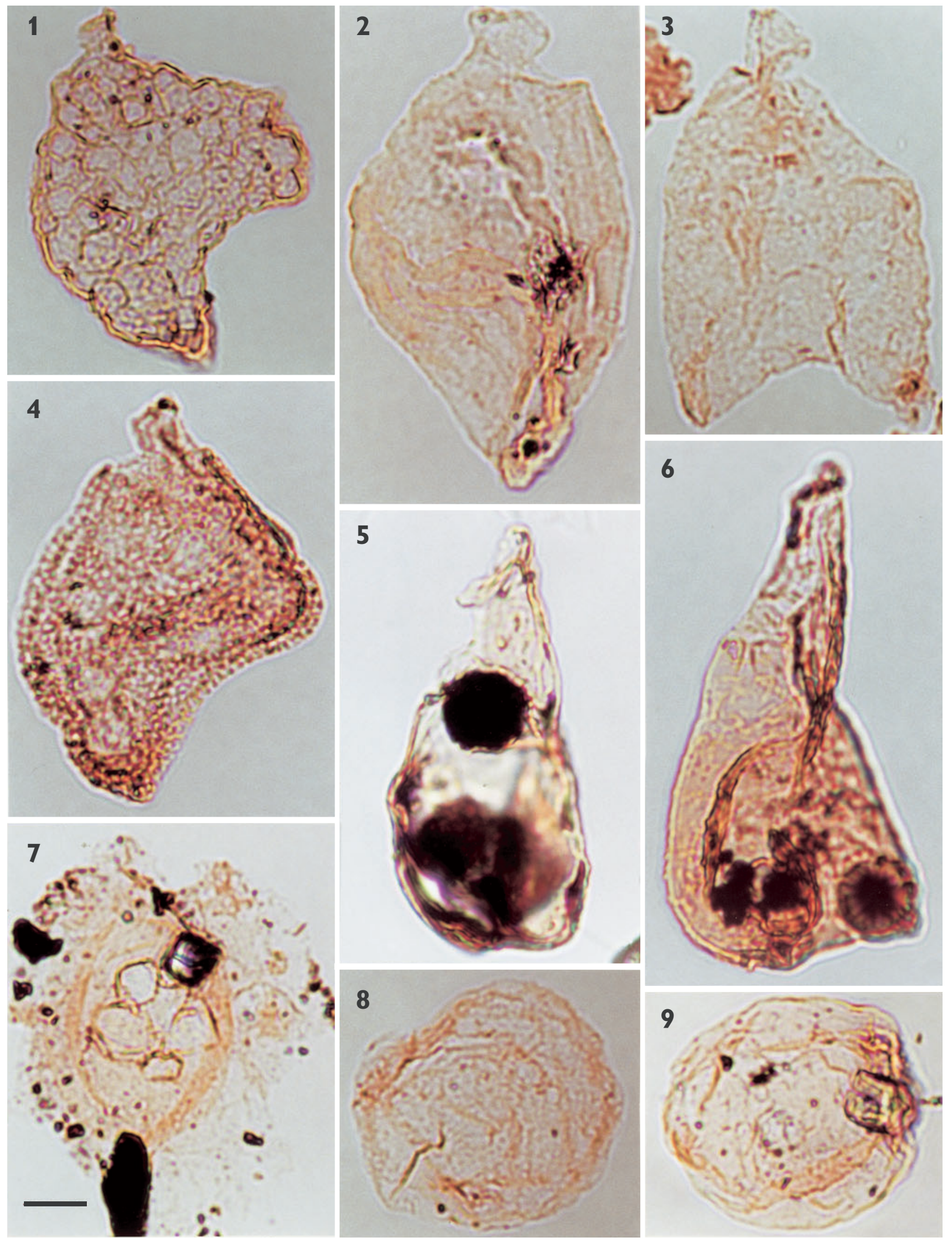




\section{Plate 5}

Palynomorphs from the Neill Klinter Group at the Albuen section. The scale bar is 10 microns.

Fig. 1. Mancodinium semitabulatum.

Sample 405466-3, EFR H531.

Fig. 2. M. semitabulatum.

Sample 405411-3, EFR H37.

Fig. 3. Mendicodinium reticulatum.

Sample 405422-3, EFR M292.

Fig. 4. M. reticulatum.

Sample 405420-3, EFR F381.

Fig. 5. Luehndea spinosa.

Sample 405466-3, EFR F554.

Fig. 6. Wallodinium laganum.

Sample 405452-3, EFR F573 
1

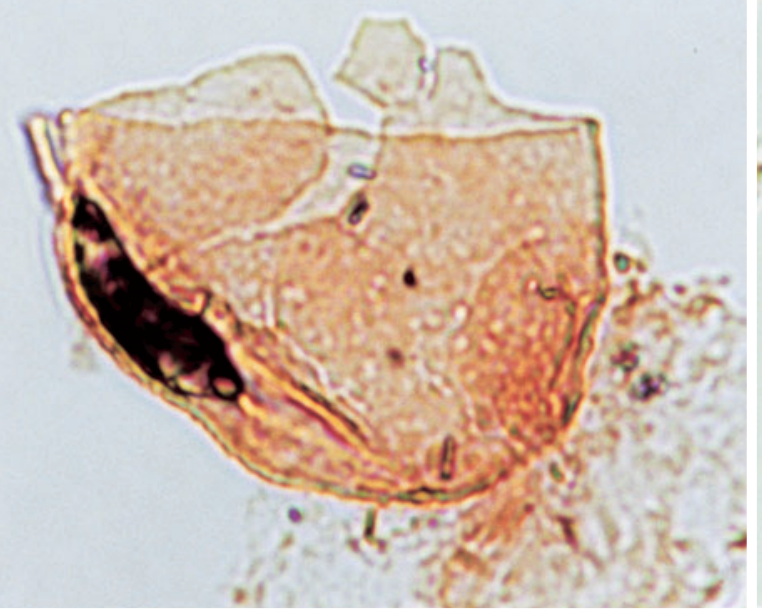

\section{3}
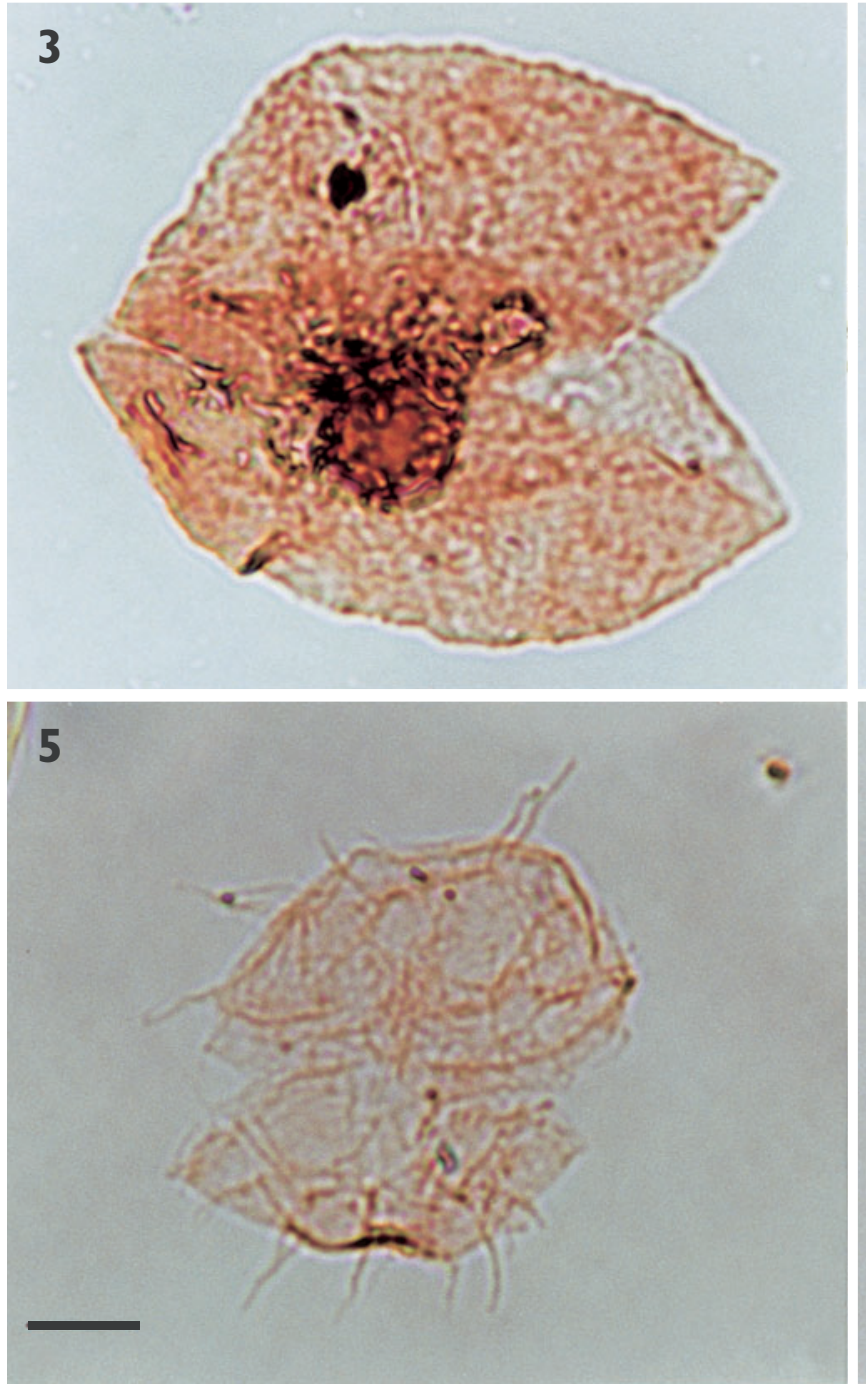

2

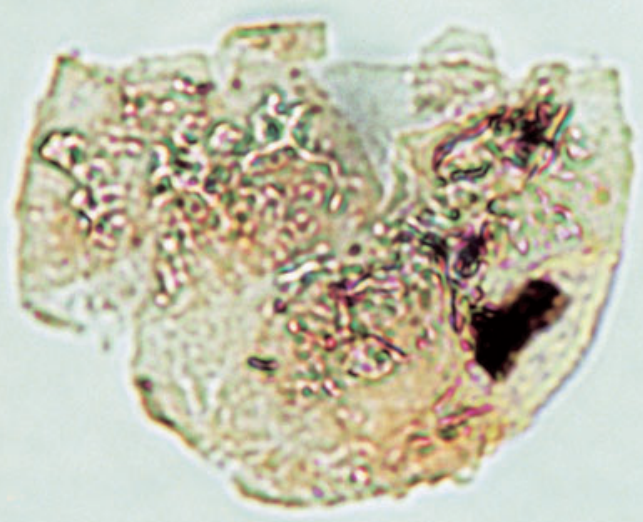

4

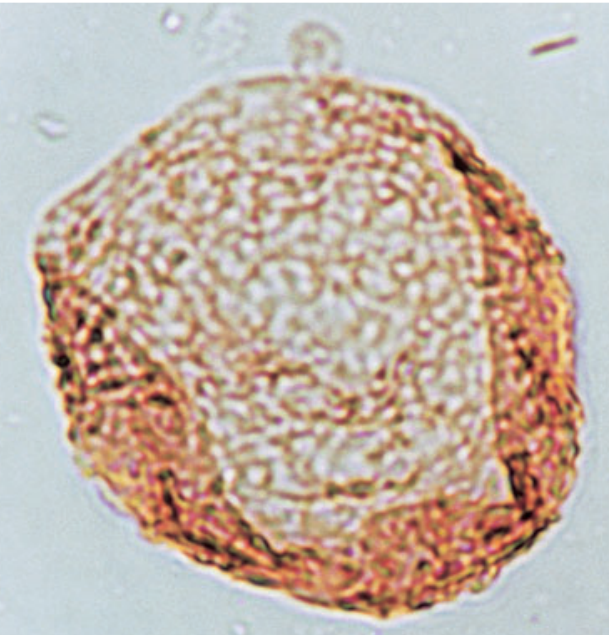

6

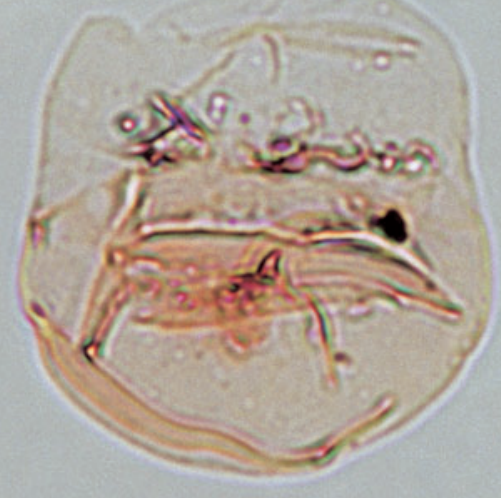




\section{Plate 6}

Palynomorphs from the Neill Klinter Group at the Albuen section. The scale bar is 10 microns.

Fig. 1. Limbicysta bjaerkei.

Sample 405456-3, EFR N244.

Fig. 2. L. bjaerkei.

Sample 405449-3, EFR E221.

Fig. 3. L. bjaerkei.

Sample 405405-3, EFR R484.

Fig. 4. Dissiliodinium sp.

Sample 405454-3, EFR P204.

Fig. 5. Dissiliodinium sp.

Sample 405456-3, EFR H304.

Fig. 6. Botryococcus sp.

Sample 405401-4, EFR X334.

Fig. 7. Botryococcus sp.

Sample 405401-4, EFR T242. 


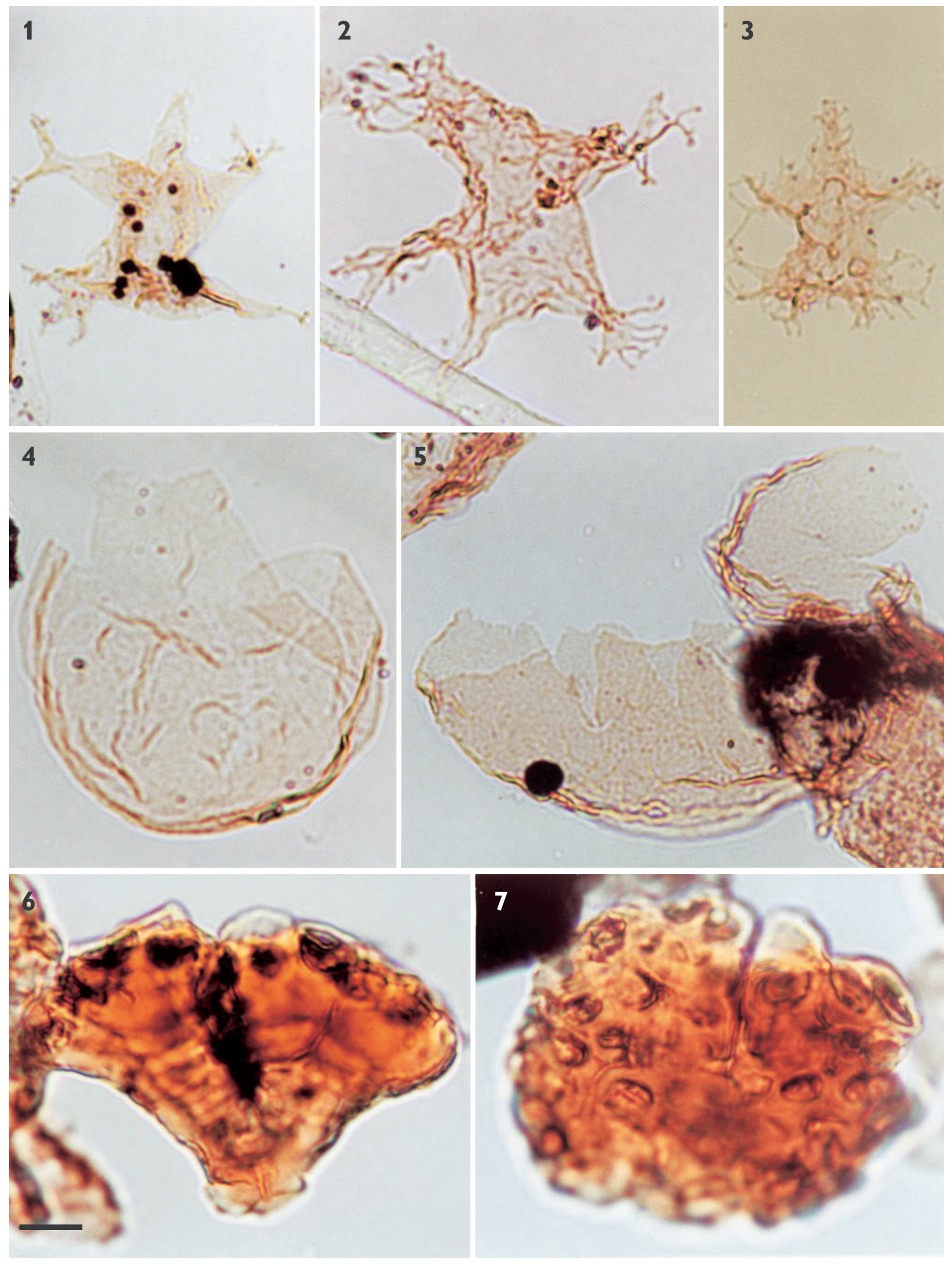




\section{Plate 7}

Palynomorphs from the Neill Klinter Group at the Albuen section. The scale bar is 10 microns; this scale bar is not applicable to figure 7 .

Fig. 1. Celyphus rallus.

Sample 405466-3, EFR E21.

Fig. 2. Leiofusa jurassica.

Sample 405414-3, EFR O404.

Fig. 3. Veryhachium collectum.

Sample 405414-3, EFR O403.

Fig. 4. V. formosus.

Sample 405408-3, EFR L353.

Fig. 5. Lecaniella foveata.

Sample 405454-3, EFR W401.

Fig. 6. Tetraporina compressa.

Sample 405419-3, EFR K504.

Fig. 7. Foraminiferal lining, 132 microns in diameter.

Sample 405464-3, EFR P292. 


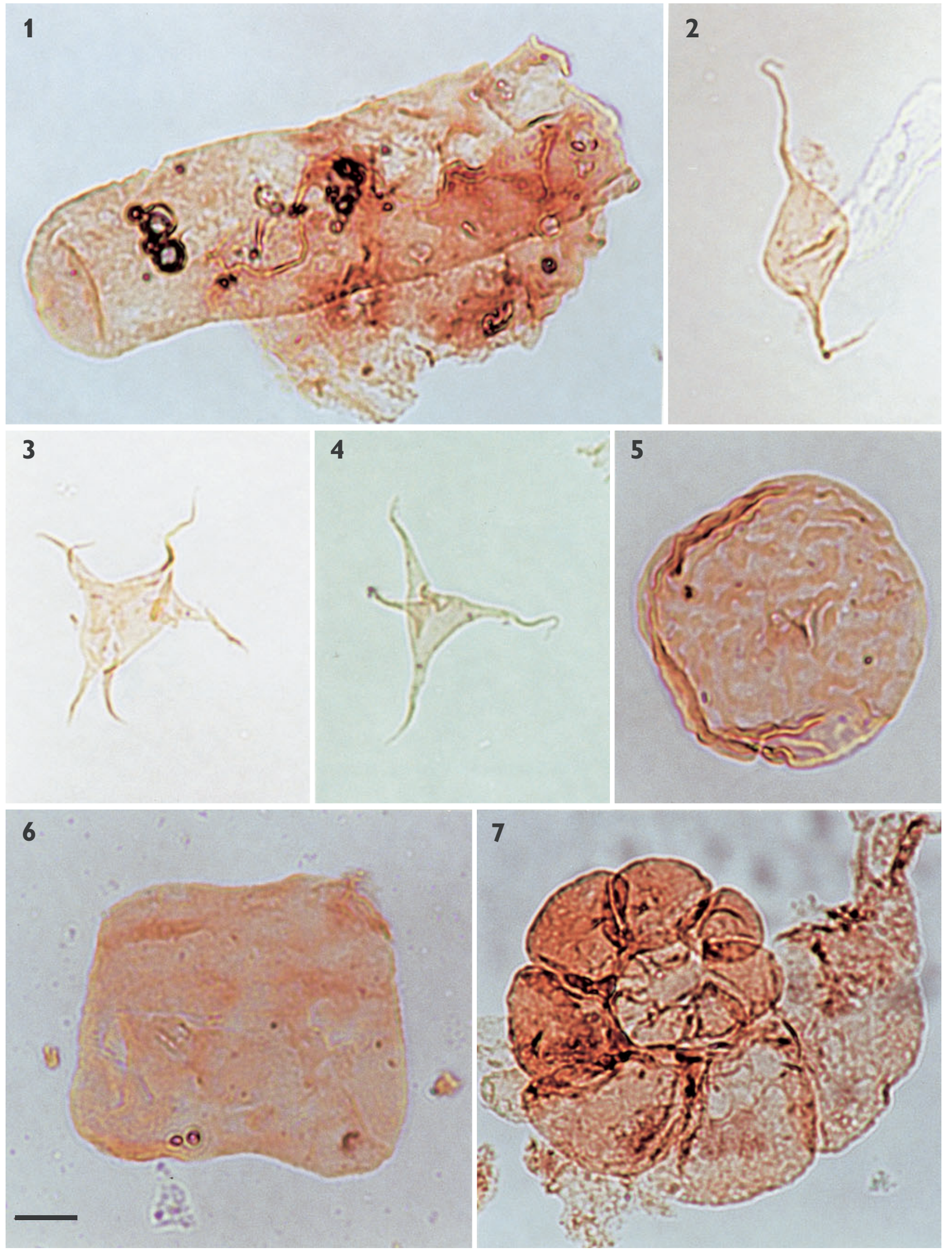




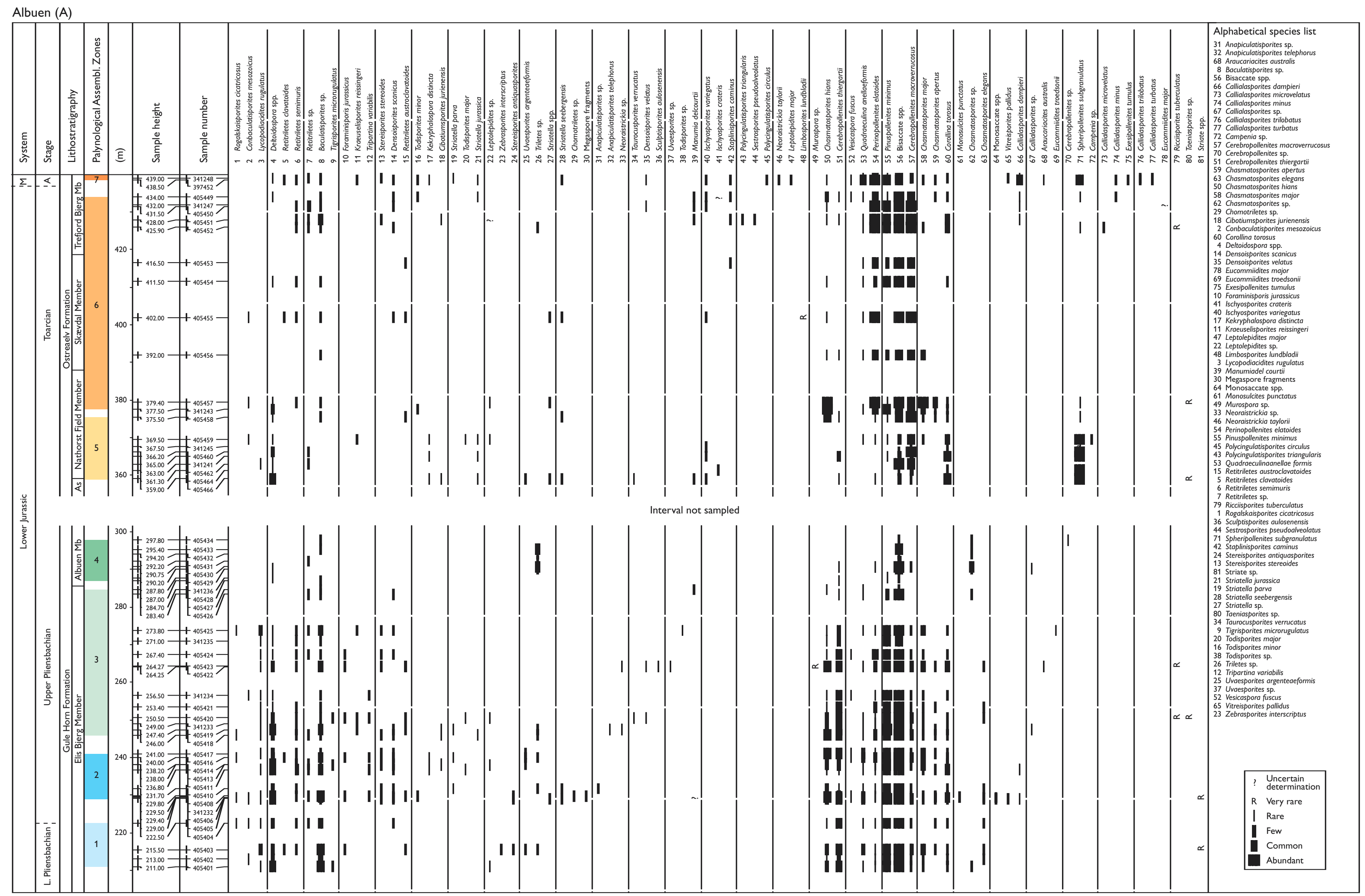

Fig. 4A. Terrestrial palynomorph distribution chart for the Gule Horn and Ostreaelv Formations at Albuen (for location, see Fig. 1). M, Middle Jurassic; A, Aalenian; As, Astartekløft Member. 


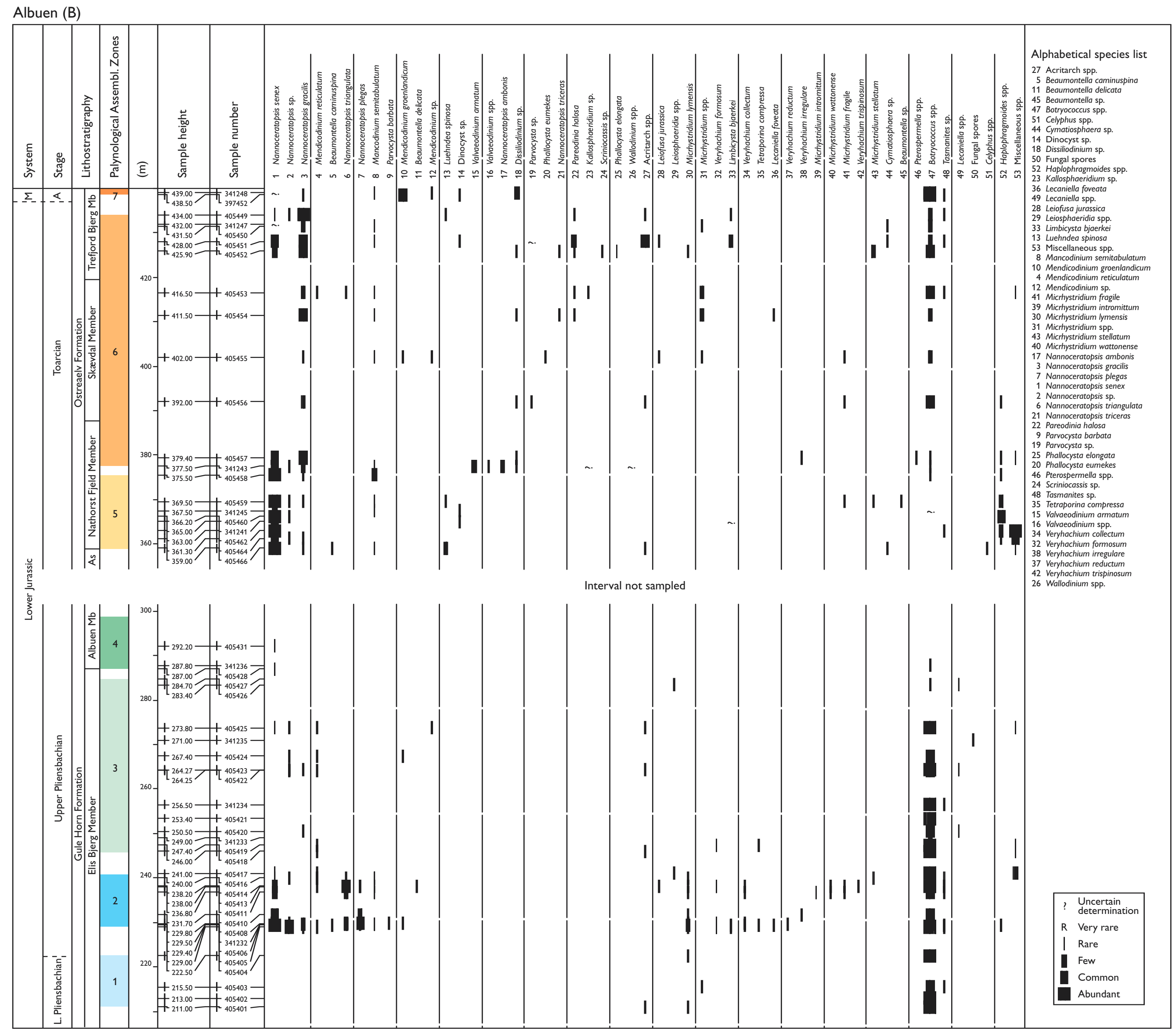

Fig. 4B. Marine palynomorph distribution chart for the Gule Horn and Ostreaelv Formations at Albuen (for location, see Fig. 1). M, Middle Jurassic; A, Aalenian; As, Astartekløft Member. 


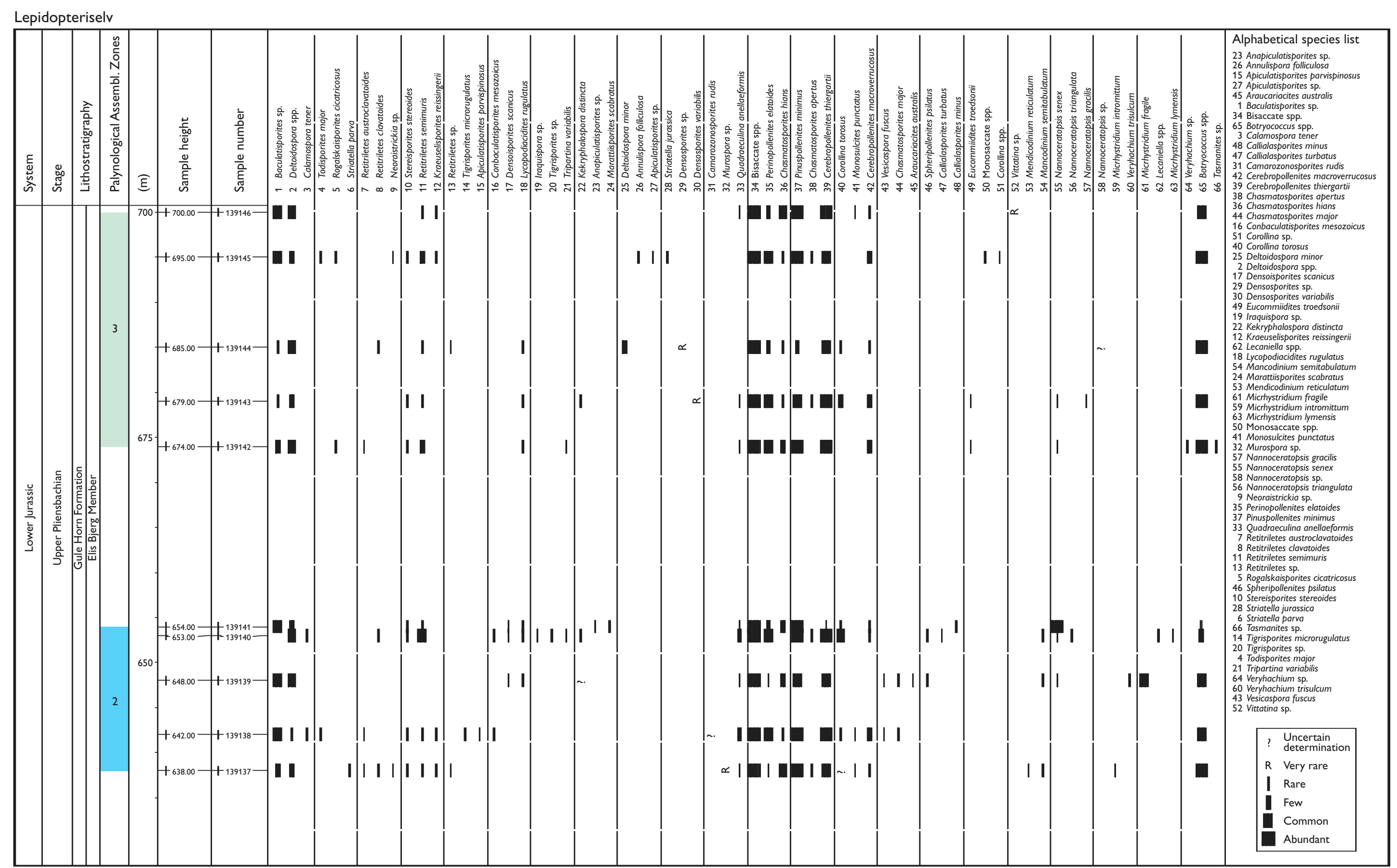

Fig. 13. Palynomorph distribution chart for the Gule Horn Formation (Elis Bjerg Member) at Lepidopteriselv (for location, see Fig. 1). 